\title{
The Impact of Study and Learning Strategies On Post-Secondary Student Academic Achievement: A Mixed-Methods Systematic Review
}

April 13, 2021

${ }^{1} \mathrm{~J}$ oy Xu, ${ }^{1}$ Jeffrey Ong, ${ }^{3}$ Tam Tran, ${ }^{1}$ Yasmine Kollar, ${ }^{1}$ Alyssa Wu, ${ }^{1}$ Milena Vujicic, ${ }^{2}$ Helen Hsiao

${ }^{1}$ McMaster University, Hamilton, ON, Canada

${ }^{2}$ University of British Columbia, Vancouver, BC, Canada

${ }^{3}$ University of Toronto, Toronto, ON, Canada

Contact Info: joyxu@gmail.com

\begin{abstract}
Background:

Within academic development, it is important for students to use effective study strategies to facilitate learning. Techniques used for long-term information retention include note taking strategies, time management, methods of self-testing and active recall. These strategies are explored to help students learn more effectively to attain their academic goals.
\end{abstract}

Methods:

A mixed-methods systematic review of peer-review articles and grey literature was conducted with a predetermined criteria for a convergent integrated synthesis approach. PsychInfo (Ovid), Web of Science, and ProQuest databases were searched with guidance of a PICO-P logic grid and search strategy using keywords of student, study strategies, and achievement alongside filters. Initial studies were screened and reconciled by two independent authors with the use of a piloted screening tool. Using the Mixed Methods Assessment Tool (MMAT), included studies were assessed for quality. Two authors independently performed data extraction. Heterogeneity in study designs, outcomes, and measurements precluded meta and statistical analyses; thus, a qualitative analysis of studies was provided.

\section{Results:}

Four major themes contributing to academic performance were identified among the appraised articles. These themes were self-testing, scheduling/time management, concept maps, and learning styles. Self-testing, scheduling, and concept maps were positively correlated with increased academic performance, while no correlation was found with learning styles and academic performance.

\section{Conclusion:}

Included studies provided evidence for significant differences in study strategies implemented by high and low achieving students, such as areas of motivation for learning, efficiency, active recall, retrieval practices, and concept maps. Understanding the effectiveness of certain study strategies is critical for students and educational facilitators to maximize learning. 


\section{KEY WORDS}

(study strat* AND student*) OR (study strat* AND achievement)

\section{INTRODUCTION}

The transition to post-secondary studies is a challenging journey for many students, particularly within academia. Educational conventions and schedule changes require most college students to determine study strategies on an individual-basis through trial and error. A study asked 177 undergraduate students to rank the strategies implemented when studying (1). Many methods of learning, including self-studying, active, and retrieval-related methods (e.g., flashcards, past tests) were commonly listed, where $83.6 \%$ of students enlisted rereading notes as the most common learning strategy. However, rereading notes is evidenced as a passive and inefficient study strategy, thereby indicating a gap within student knowledge regarding awareness on effective study strategies. Within studying, passive engagement serves ineffectively as newly learned information may only be encoded in short-term memory. Students may be able to recall limited amounts of information for an upcoming evaluation, but will find application-based questions to be significantly more challenging due to lack of strong foundational comprehension of materials. Thus, rereading, highlighting, or underlining study material serve as overall less effective and passive study strategies commonly adopted by low-achieving students (2). Contrastingly, self-testing is a method of retrieval practice used to build long-term retention of newly learned material (3). Although some students reported using the self-test method, most justified the choice as a strategy to test their knowledge of the material and gauge the amount of time needed to further engage with content. These strategies fluctuate frequently amongst students, which reflects the uncertainty that many students have when it comes to effective study habits.

Effective study strategies (including efficient note-taking, time management, and active recall methods) are an important key to academic success. Study strategies involve choosing study materials best suited for the student's unique way of learning. Study materials are learning tools that assist students in further synthesizing and reorganizing content such as flashcards, note-taking and concept map templates (4). Note-taking strategies involve learning how to extract important information from a lecture or textbook reading, and can play a significant role in the study process and the foundation for practicing good study strategies. For project management and study task prioritization, creating a to-do list allows for effective planning and scheduling. A study investigated the advantages to employing higher working memory, the capacity to prioritize and remember important information (5). The researchers used recall tasks to design experiments testing participants' recall accuracy. With descriptive statistics, a relationship was determined between working memory and recall, as well as between working memory and selectivity. These were measured and scored as the proportion of obtained points 
and maximum points against the possibility of gaining chance points. Statistical significance was determined with all 4 experiments scoring over $88 \%$ in reliability. Thereby, these relationships indicate importance in setting attainable long-term and short-term goals to stay productive.

Active recall and spaced learning are effective strategies to retain information for longer periods of time, such as using flashcards or teaching unfamiliar concepts to others. The forgetting curve, founded by psychologist Hermann Ebbinghaus, displayed negative correlation between information retention and time (6). Spaced repetition encompasses re-exposure to information, which further solidifies memories (7-9). Thereby, spaced learning disrupts the forgetting curve, to allow for new information to be encoded in long-term memory. With increased intervals of revisiting material, more time can be provided between each successive session.

Another issue that can reduce efficient information retention is multitasking. A study examined the impacts of multitasking on academic performance and learning outcomes. When students attended to two sources of information, these students showed poorer learning outcomes $(p=$ 0.023 ) with limited accuracy in memory retention. However, when asked to only focus on one source of information, working memory capacity was improved $(p=0.080)$ and students were also more confident in learning effectiveness. Thus, multitasking has shown a decrease in the amount of information recalled when evaluated, compared to those who focused on a single task (10). Within multitasking, task switching occurs when attentional resources are shifted to complete another task set $(11,12)$. When constantly switching between tasks, the brain requires additional time to refocus due to the increased demand for working memory processing, which may easily disrupt productive workflow (12). Therefore, it is highly recommended that one focuses on one task to be completed at a time and avoid task-switching. The Pomodoro technique is gaining popularity among students for help with time management.

A study on 623 college students in an introductory biology course in 2019 came to the conclusion that college students used four strategies on average when studying, with half of the strategies identifying as active recall methods. Students who used more active study strategies for longer periods of overall study time were seen to have more positive reflection in their marks. Although students began studying six days before for an exam on average, the amount of days spent preparing in advance did not correlate with increased performance. College students also reported being distracted $20 \%$ of the time during study sessions. Amount of time spent studying, types of strategies used and minimizing distractions are all significant factors that contribute to a students' overall academic performance, which must be further analyzed (13). In relation to specific study strategies, researchers determined common study methods to include completion of past exam questions (100\% of students), rereading material (92.3\% of students), explaining concepts to peers (7.7\% of students), and using flashcards (7.7\% of students) (14). Study strategies are highly variable and many factors must be taken into account, including the unique learning styles of students. 
The aforementioned study strategies focus on developing a deeper understanding of material and content. Mastering these study techniques will support goal orientation, with a clear objective and intentions in mind. Effective application of study strategies will support student familiarity of newly learned concepts and ideas, particularly for application in different problem-solving scenarios. Among 931 undergraduate students in an introductory biology course, high academic achievers were found to implement more self-testing strategies, less likely to study last minute, and more likely to plan a study schedule in advance (15). A good learning attitude, self-motivation and proficiency in adapting better learning and study strategies are correlated with higher academic achievement (16). These students are also aware of long-term goals, such as pursuing a dream career, and strengthening effective learning strategies is critical for success as lifelong learners.

This systematic review aims to answer the following questions: What are the most effective study and learning strategies that result in higher academic achievement? Through conducting detailed studies and consulting experts in the field, this systematic review will contribute towards a deeper understanding of specific effective study strategies. Specifically, present literature will be examined to determine potential avenues to increase academic achievement by building on study habits and learning strategies.

\section{METHODS}

To determine the effectiveness of study and learning strategies on student achievement, a systematic review was conducted for peer-reviewed and grey literature from January to May 2021, using search strategies including keywords, truncations, and booleans. The current review was conducted and reported in accordance with the Preferred Reporting Items for Systematic Reviews and Meta-Analyses (PRISMA). The protocol of this systematic review was registered with PROSPERO (record ID: CRD42021234245). PROSPERO is an international database of prospectively registered systematic reviews in health and social care.

\section{Study design and setting}

This systematic review aims to assess effective study strategies to be integrated towards virtual interventions, particularly within the development of the Felicity App. The Felicity App is a virtual application targeting young adults aged 15 to 40 years old. Felicity aims to support productivity enhancement through psychological interventions in various aspects, including positive reinforcements for educational/work productive behaviours. App features will also include productivity tools such as to-do lists, calendars, and reminder notifications. Positive reinforcement tools include psychological interventions like mental health exercises (such as self-affirmations, mindfulness, and other techniques), time management tips (delivered through notifications and avatar narratives), and positive reinforcement rewards for productive behaviours (through point-systems and potential leaderboards). The Felicity App aspires to guide 
students into becoming independent, self-regulated learners by encouraging students to choose appropriate strategies, set goals, reflect on performance and modify accordingly.

This systematic review investigated the effectiveness of learning strategies to determine the pertinence of selected literature to improve student academic performance and productivity. A virtual application setting was chosen as the medium to deliver the functions available in the Felicity App due to its accessibility, convenience, and wide usage amongst the target age group of individuals between the ages of 25 and 40. The mixed-method study design was employed to analyze both qualitative and quantitative psychological behaviour research data related to study or learning strategies.

\section{Inclusion/Exclusion Criteria}

The inclusion/exclusion criteria was predetermined, where included studies consisted of undergraduate or professional school students aged 18-40 years old with no pre-existing physical/mental conditions. Eligible studies measured academic achievement as Grade Point Average or test performance of students while comparing those using study or learning strategies against non-users. Only primary studies and grey literature were included, where systematic reviews, literature reviews, and opinion texts were excluded as secondary literature. Reference lists of included articles were hand searched and screened for potential inclusion. Studies were excluded if test outcomes did not compare before and after the implementation of study or learning strategies or if outcomes did not compare differences in strategies between high- and low-achieving students. Studies were also excluded if the sample consisted of a single gender or if the study setting was an under-developed country.

\section{Search strategy}

A logic grid was constructed to guide the search strategy aligned with the PICO - P (population): undergraduate or professional school students; I (intervention): study or learning strategies; C (comparison): compared to subjects that do not use any study or learning strategies; $\mathrm{O}$ (outcome): increased academic performance (GPA, test score).

A diverse selection of literature, which included grey, was reviewed based on a predetermined inclusion/exclusion criteria. The databases searched were PsychInfo (Ovid), Web of Science, and ProQuest for the period of January 1990 to December 2021 using keywords and subject headings related to learning strategies and college student academic performance. The key terms used in building the search strategy for the Databases were student, study strategies, and achievement (see Appendix 1 for the complete search strategy and Appendix 2 for the grey literature search strategy). The key terms were combined using Boolean operators to search the electronic Databases. In addition, filters were applied to each database to optimize relevance for study inclusion. For PsychInfo, results were filtered by subjects of academic achievement, college students and learning. For Web of Science, results were filtered under the subject of psychology, 
and results found within ProQuest were filtered under the subjects of college students and academic achievement.

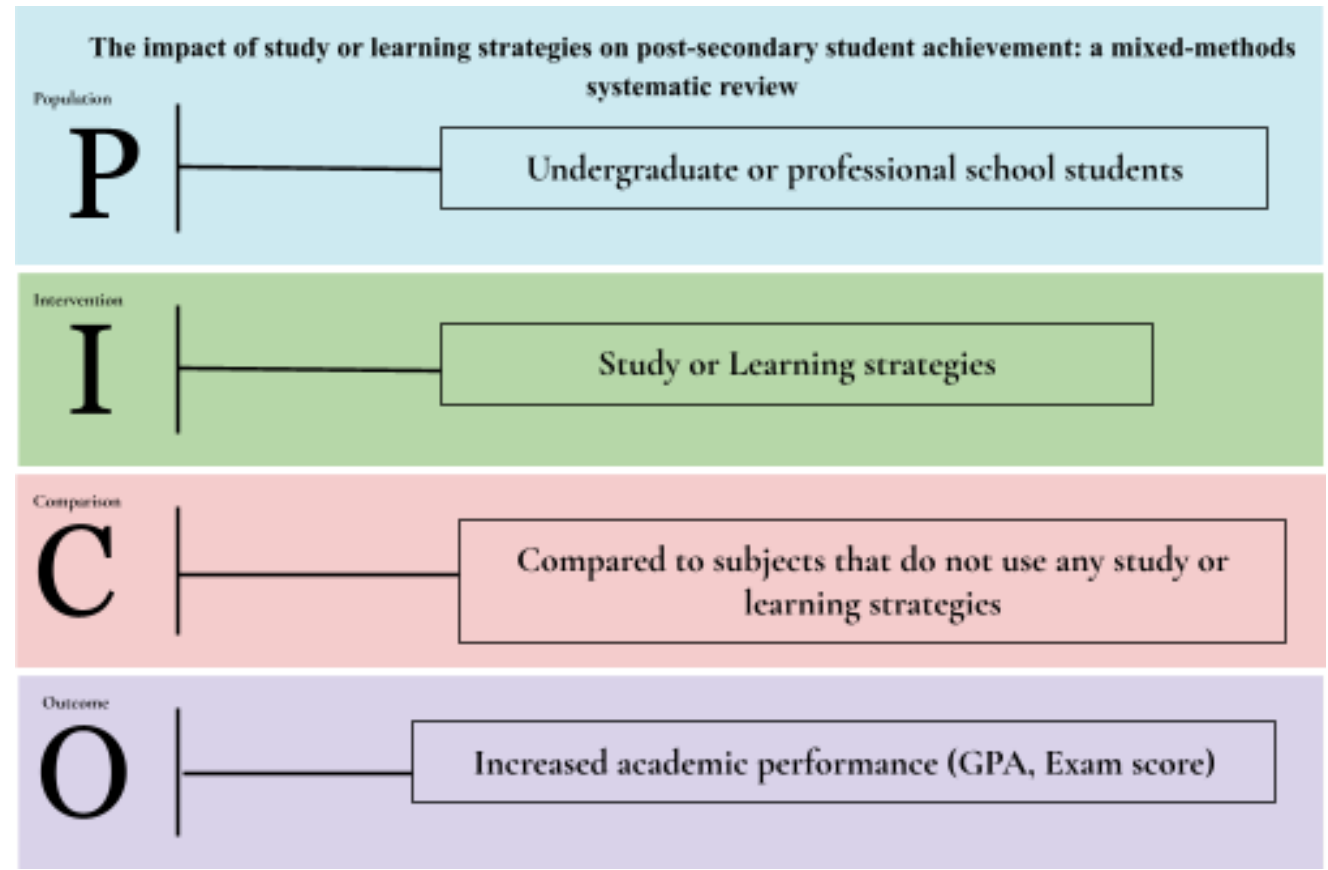

Figure 1. Research question in PICO format.

\section{Data collection and abstraction}

Collection of data was first done by gathering database search results and removing any duplicate literature pieces using Endnote (version X8.2). Endnote is a commercial reference management software package used to manage bibliographies and references.

An abstract screening tool, consisting of 9 questions, was created using inclusion and exclusion criteria to ensure only relevant data would be collected. A pilot test of the abstract screening tool was done with 25 articles using our search strategy found in a database different from the ones used in the study. Initial pilot testing resulted in an accuracy score of $40 \%$. Three independent authors reconciled discrepancies and modified the screening tool to consolidate objectivity and accuracy of the tool. Re-testing of the screening tool resulted in an accuracy score of $77 \%$. Two review authors applied the modified screening tool to the final list of peer-reviewed and non-peer-reviewed articles and analyzed specific sections of the literature, including purpose, methods, results, and potential future applications or improvements. Upon its integration with the collected data, two review authors independently used the tool to analyze titles and abstracts, with a third review author present to resolve any disagreements. Articles that were considered relevant remained for another round of screening, in which the same two authors independently performed a full-text analysis to include and exclude articles according to the eligibility criteria. 
Hand-searches were then performed independently to fill in any gaps in the literature from the initial search strategy. The same two review authors independently applied the screening tool and performed the same two-step process to eliminate irrelevant literature. Screening of all relevant literature was completed on February 14th, 2021. A final list of screened articles were further processed during data extraction, where MMAT quality appraisal methods were implemented.

\section{Assessment of study quality, certainty of evidence, and limitations}

The Mixed Methods Assessment Tool (MMAT) was used to assess the quality of the articles from a final list of 98 articles obtained after full text screening, including grey literature and hand searched articles. This process was performed independently by two authors from February 17th to February 21st, 2021. The MMAT is an appraisal tool used to assess the methodological quality of articles organized into five categories: qualitative research, randomized controlled trials, non-randomized studies, quantitative descriptive studies and mixed methods studies. Each category had five criteria to rate, and all articles were kept despite their overall rating. Articles that were removed included duplicates and retracted articles. Reconciliation between the two authors followed with disagreements settled with a third author. A list of 67 quality appraised articles with respective MMAT scores were produced.

It was crucial to ensure that similar external conditions were shared among all papers, including the state of the country (developing or developed countries), and how they may compare to the target state, as some may have different standards in comparison to general developed countries. This characteristic was not included in the quality assessment, but to ensure the papers fit that criteria, an analysis on the state of every article's origin country was done during the first screening protocol. In terms of the structure of MMAT assessments, there have been various discrepancies in previous reliability tests regarding "non-randomized" (classified as set 3 ) and "qualitative" (classified as set 1) sections (17). Due to the more complex analysis provided in these types of papers, these discrepancies may be due to varying perspectives by those completing the quality assessment. In order to secure objective and accurate evaluations, this uncertainty was resolved during reconciliation, where quality assessment members discussed any inconsistencies and agreed on a final assessment that best reflected the article.

\section{Data extraction}

Data was extracted by two authors independently, and took place from March 7th to March 12th, 2021. A table was created and data was extracted based on the categories: First author and title of included study, country, study design, duration, participant information, type of data, summary of the main outcomes, and quality/design score obtained from the process mentioned in the prior section. Authors reconciled disagreements from March 13th to March 14th, 2021. 
After full text screening, 186 articles were included. After quality appraisal conducted independently, 67 articles remained after duplicates were deleted. 54 articles remained after quality appraisal reconciliation.

Table 1. Study characteristics

\begin{tabular}{|c|c|c|}
\hline Study Criteria & Sub-categories & $\begin{array}{l}\text { Number of Studies } \\
\text { belonging to each } \\
\text { Sub-category }\end{array}$ \\
\hline \multirow[t]{5}{*}{ Study design } & Qualitative research & 6 \\
\hline & Randomized controlled trials & 4 \\
\hline & Non-randomized studies & 8 \\
\hline & Quantitative descriptive studies & 36 \\
\hline & Mixed methods studies & 0 \\
\hline \multirow{3}{*}{$\begin{array}{l}\text { Study population } \\
\text { (participants) }\end{array}$} & Undergraduate students & 35 \\
\hline & $\begin{array}{l}\text { Graduate/professional school students } \\
\text { (medical, dental, pharmacy, nursing etc.) }\end{array}$ & 11 \\
\hline & Unspecified/no participants & 8 \\
\hline \multirow[t]{4}{*}{ Study setting (country) } & United States & 36 \\
\hline & China & 5 \\
\hline & The Netherlands, Ireland & 2 \\
\hline & $\begin{array}{l}\text { India, Turkey, Norway, Qatar, United Arab } \\
\text { Emirates, Finland, Taiwan, Belgium }\end{array}$ & 1 \\
\hline \multirow[t]{4}{*}{ Year published } & $1990-1999$ & 4 \\
\hline & $2000-2009$ & 12 \\
\hline & $2010-2019$ & 37 \\
\hline & $2020-2021$ & 1 \\
\hline \multirow{4}{*}{$\begin{array}{l}\text { Type of data in study } \\
\text { (many studies had overlaps in } \\
\text { type of data used) }\end{array}$} & Questionnaire-based studies & 42 \\
\hline & Intervention-based studies & 11 \\
\hline & Observation-based studies & 10 \\
\hline & Paper-based studies & 5 \\
\hline
\end{tabular}




\begin{tabular}{|l|l|l|}
\hline & Meta-analysis studies & 2 \\
\hline $\begin{array}{l}\text { Study quality: MMAT design } \\
\text { score }\end{array}$ & 5 rating & 20 \\
\hline & 4 rating & 28 \\
\hline & 3 rating & 6 \\
\hline & 2 rating & 0 \\
\hline & 1 rating & 0 \\
\hline
\end{tabular}

\section{RESULTS}

\section{Search results and screening}

The search and identification of potential records were conducted by JO and MV from January 2021 to February 2021 (Fig. 2 PRISMA flow diagram). The database and hand-search identified 585 records, of which 38 were duplicates. JO and MV screened articles at the title and abstract level. Both screeners considered one hundred and eight-six full-text articles for inclusion, but only fifty-three records met the inclusion criteria (Fig 2. PRISMA flow diagram). One hundred and thirty-three studies were excluded because participants consisted of students from secondary or primary schools, academic performance was not measured, the study was not written in english, or the sample size was below 50 (see Appendix 3 for a list of excluded studies). 


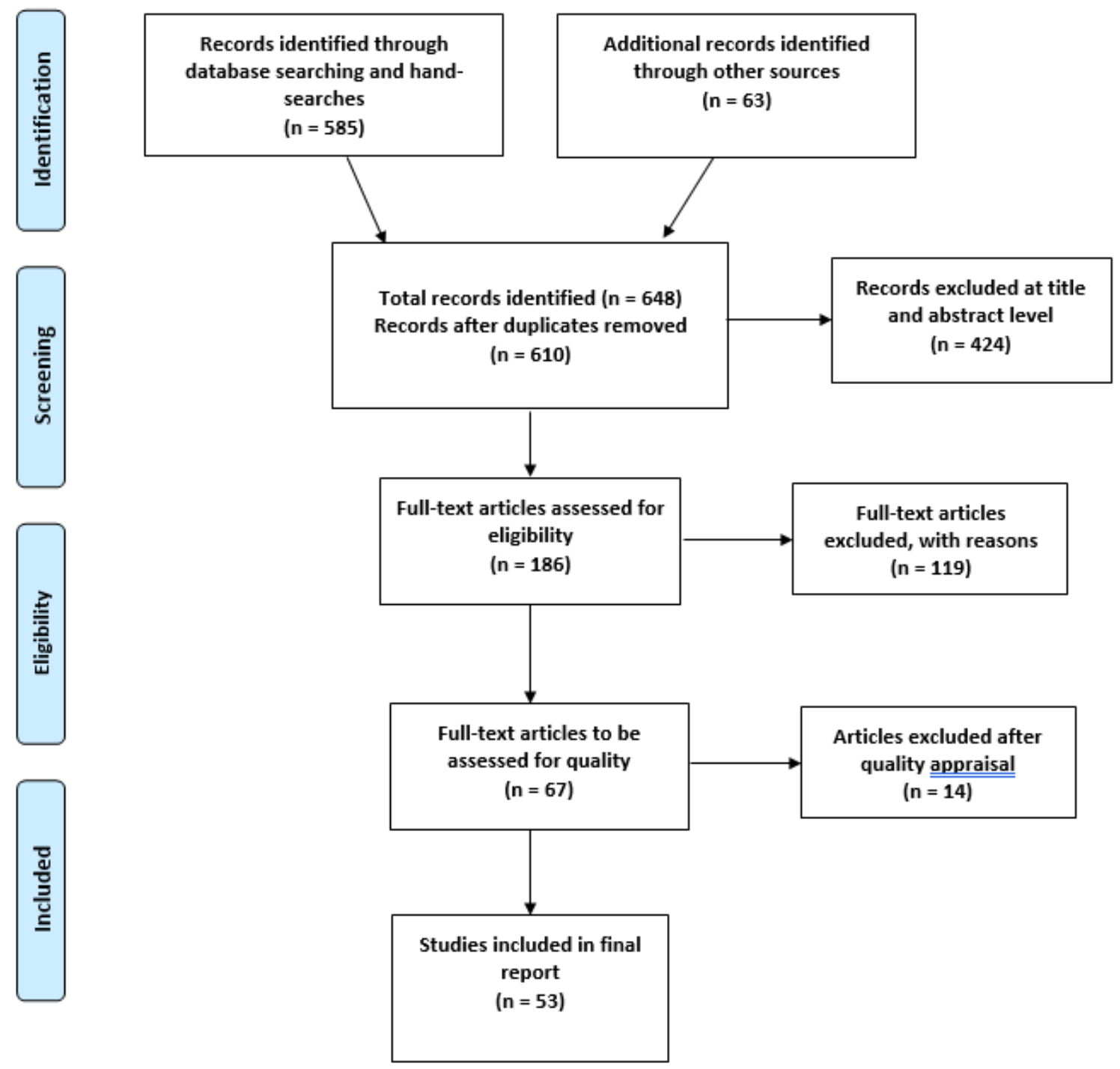

Figure 2. PRISMA (preferred reporting items for systematic reviews and meta-analyses) flow diagram.

\section{Study Characteristics}

Of the fifty-three papers included in this review, six were qualitative, four were randomized control trials, eight were non-randomized trials, and thirty-six were quantitative descriptive studies. Forty-two articles were questionnaire-based studies, eleven were intervention-based studies, ten were observational studies, five were paper-based studies, and two were meta-analyses. Twenty articles were given a 5 star quality rating, twenty-eight were rated 4 stars, and 6 were rated 3 stars. In terms of study settings, thirty-six articles were published in the United States, five published in China, two in the Netherlands and Ireland each, and one was published in India, Turkey, Norway, Qatar, United Arab Emirates, Finland, Taiwan, and Belgium 
each. Thirty-five articles focused on studying undergraduate student populations, eleven articles based on graduate or professional school students (i.e., medical, dental, pharmacy, nursing, etc.), and 8 articles had unspecified or no participants. In terms of year published, four articles were published from 1990 to 1999, twelve articles were published from 2000 - 2009, thirty-seven articles were published from 2010 to 2019, and one article was published most recently from 2020 to 2021. See study characteristics in Appendix 4.

\section{Main Findings}

Due to the variability of the studies and result measurement resulting in study heterogeneity, the findings from the studies were extracted and synthesized qualitatively to compare outcomes. Four themes from the literature were identified. These themes included self-testing, scheduling, concept maps, and learning styles. It was found that these themes were nuanced and interrelated. Self-testing refers to a specific category of study strategies involving evaluation of one's knowledge and understanding of course material through retrieval or recognition practice. Sixteen articles demonstrated a significant positive correlation between self-testing and academic performance.

Scheduling/Time management refers to the creation of a schedule with concrete dates and times to review course material and study. Ten articles demonstrated a positive correlation between scheduling strategies and academic performance.

Concept maps refer to the visual organization and representation of knowledge that depicts suggested relationships between ideas. Three articles explored the validity of concept map usage for self-assessment of course material.

Learning styles refer to the preferential way in which a learner absorbs, processes, comprehends, and retains information. Seven articles discussed the correlation between VARK learning styles and academic performance.

\section{DISCUSSION}

This systematic review provides a comprehensive examination of the current literature regarding the topics of learning strategies aimed towards improving student academic performance. The results from this systematic review suggest that the outcomes for students are mixed and did not always result in increased performance. Generally, the implementation of study and learning strategies was associated with increases in test scores and Grade Point Average (GPA), but variation in the significance and level of improvement in performance was evident with different strategies and assessment methods. It was found that self-testing, scheduling, concept maps, and learning styles were the four major themes discussed in the literature. Self-testing, scheduling, and concept maps were positively correlated with increased academic performance, while no correlation was found with learning styles and academic performance. Each of the four themes will be discussed below.

\section{Self-Testing}


The following studies revealed self-testing as one of the best predictors of strong academic performance. Through the use of the Learning and Study Strategies Inventory (LASSI), self-testing was measured as one of the cognitive abilities and comprehension monitoring strategies used by students to assess their ability to review course material (19). A strong, positive correlation between self-testing and a high Grade Point Average (GPA) is apparent across all studies, where students who implemented effective self-testing strategies obtained greater achievement (20). Specifically, students with higher academic achievement scored higher on the self-testing subscale of LASSI, whereas students with lower academic achievement scored lower $(21,22)$.

Although self-testing can be used as a metacognitive tool to evaluate progress and as a learning strategy to boost performance, high-achieving students reported using self-testing metacognitively more frequently (23). This finding suggests that self-testing is most effective when it is used to monitor how well the information has been learned as opposed to how familiar a certain concept is. This explains why the use of flashcards (one of the most popular self-testing methods) and similar retrieval-type strategies were found to be not significantly related to GPA (24). As flashcards may operate on the basis of passive-learning where students may not fully understand the presented factual information, this ineffective approach may be omitted and replaced with self-testing by introducing short concept-check practice questions to encourage deeper mental processing (25). This method will allow users to not only actively process the recently-learned information, but also reflect on their thinking patterns and face knowledge gaps which might have otherwise been ignored through the use of flashcards (26).

\section{Scheduling/Time Management}

A number of the included studies ( $n=10)$ elicited students to implement a study schedule and dedicate specific parts of the day to studying $(2,15,28,24,40)$. The results from the included papers suggest a strong positive correlation between scheduling strategies and academic performance $(20,29,30,43,44)$. Significant differences between low and high achieving students revealed an increased use of study schedules and stronger time management skills for higher achieving students. While lower achievers were characterized by a focus on impending deadlines and studying late at night, higher achievers were characterized by planned study schedules and spaced practice. Moreover, one article implemented a study strategy course where students were taught how to create study schedules (45). Results from these studies indicated an increase in GPA, which is linked to better understanding and achievement of the course material, after taking the course $(28,45)$. This suggests that students were capable of learning and adopting specific strategies which could then translate to increased academic performance.

\section{Concept Maps}


A concept map is an uncommon strategy when studying and was more often used for self-assessment of knowledge $(n=3)$. A positive correlation was found between concept map usage and academic performance, suggesting concept maps may be an effective and viable study strategy $(31,32)$. Concept maps allow students to generate a visual representation of information and generate relationships between connected ideas (33-35). Typical reviewing strategies such as highlighting and re-reading notes showed no significant relationship (28) with concept map outcomes, suggesting a deeper level of understanding is required in order for concept maps to be effective at assessing learning. Strategies that involve deeper processing of information (36) such as self-testing followed by the creation of a study map may result in more stronger consolidation of information. Moreover, because of the visual nature of this strategy, concept maps may show increased benefits for visual learners when compared to auditory, read/write, or kinesthetic learners $(37,38)$.

\section{Learning Styles}

In current literature outlining the influence of learning style preferences on academic performance, the VARK (Visual, Aural, Read/write and Kinesthetic) model is most utilized among other proposed types of learning style inventories. According to VARK, visual learners are those who prefer diagrammatic representations such as images and graphs, aural learners rely on auditory tools for information processing, learners who prefer to read/write often take notes and refer to written material, and kinesthetic learners learn through practice and experience (39). Although the concept of learning styles has been solidified through the VARK model, multiple studies provide evidence against the effectiveness of VARK learning styles on academic performance. As many of these studies assessed anatomy and physiology students, the collective findings support that the utilization of the VARK model in an academic setting has a limited contribution to assessment marks in these courses $(41,42)$. Moreover, the slight variance in test scores was not attributable to learning style preferences, and no learning style conferred an overall advantage $(41,42)$.

Given the well-established ineffectiveness of learning styles on academic performance across literature, implementing features which allow users to assess their learning styles through the Felicity Application should be avoided. Ensuring that Felicity focuses on providing resources pertaining to other successful study strategies instead would enable the users to improve their academic performance in a meaningful way.

\section{LIMITATIONS}

This systematic review integrated qualitative studies from peer-reviewed and grey literature within a range of literature. The holistic collection of data provides well-rounded perspectives of current data, but additional research should be pursued to assess quality and validity in greater depths. Furthermore, the data within this systematic review is limited by the searched databases and demographic restrictions. Data was not extracted from developing countries nor from 
demographics outside of the age limit. Studies written in languages outside of English were excluded and may limit the scope of the data pool. Single-site studies are found in the included studies and may limit generalizability due to insufficient support towards findings. Results obtained from retrospective studies may not apply to a general population or draw concrete also hard to generalize and draw concrete conclusions due to the nature of the retrospective design. The limitations may have also been compounded with the use of multiple reporting systems that were used to collect these data. Though these limits are pre-determined to optimize relevance with the research aims in mind, further statistical analysis is required as a qualitative synthesis of findings was used with the diverse study designs and subsequent heterogeneity in study results.

In terms of quality appraisal, MMAT is comprehensive when appraising the quality of general types of study methodologies and designs. However, it does not provide specific criteria and may leave some important information left to the discretion of quality assessors. This lack of structure provides the advantage of being applied to a wide variety of articles, and authors must pre-determine assumptions to tailor the tool towards their own set of articles. A common criteria across most MMAT categories was the representativeness of the sample in relation to the target population, but an "acceptable" percentage breakdown of genders was not specified. As a result, quality assessment members found that most psychology-based articles had significantly more female than male participants, and pre-determined an acceptable gender percentage cut off point of $33 \%$ male and $67 \%$ female subjects or a smaller difference. The titles of the articles were also considered in deciding the representative level of the sample, with more specific titles being favoured over vague titles. Specific titles include specifying details of the subject undergraduate student population, country and institution where the study was conducted, and field of study. Due to the heterogeneity and mixture of quality, additional research and quantitative analysis may be required to further support findings.

It is also important to note that because most studies calculated grade point average (GPA) as a measure of academic performance, yet this may not be the best indicator of a student's true academic abilities. There are many students who are able to retain and apply the knowledge that they have learned, but they are not able to effectively translate their knowledge well in a testing environment. Possible reasons that may be affecting a student's abilities to succeed in a testing environment could include anxiety and increased stress. These factors may cause students to overthink or misinterpret questions, which affects their overall performance on a test. Today, many courses offer other forms of assessments, such as take-home assignments, group projects, presentations and reflections. These types of assessments offer students more flexibility and the ability to reduce their stress levels, while still being able to demonstrate their knowledge using other methods of measuring academic performance. 
During the systematic review process, there were more cross-sectional studies and fewer longitudinal studies. Based on the studies that were found in our literature search, long-term effects of learning strategies cannot be elucidated. Future directions should examine the effectiveness of these learning strategies on studying, managing stress and anxiety levels, and whether students feel more confident in their academic performance over time as they implement these learning strategies.

\section{CONCLUSIONS}

Findings within present literature have determined potential virtual interventions pertaining to learning strategies and student academic performance, including motivation for learning, efficiency, retrieval practices, and self-concept. Within included studies, a distinction has been drawn between high and low academic achievers based on differences in study strategies. For instance, high academic achievers tend to implement more active recall and deep-learning processes compared to low academic achievers. Recognizing and understanding the effectiveness of certain study strategies are critical for both students and professional teaching staff to maximize content learned and application to real world situations.

\section{REFERENCES}

1. Karpicke JD, Butler AC, Roediger HL. Metacognitive strategies in student learning: do students practise retrieval when they study on their own? Mem Hove Engl. 2009 May;17(4):471-9.

2. McAndrew M, Morrow CS, Atiyeh L, Pierre GC. Dental Student Study Strategies: Are Self-Testing and Scheduling Related to Academic Performance? J Dent Educ. 2016;80(5):542-52.

3. Hotta C, Tajika H, Neumann E. Students' Free Studying After Training with Instructions about the Mnemonic Benefits of Testing. Int J Adv Psychol. 2014;3(4):127.

4. Dobson JL, Linderholm T. Self-testing promotes superior retention of anatomy and physiology information. Adv Health Sci Educ. 2015 Mar 1;20(1):149-61.

5. Griffin ML, Benjamin AS, Sahakyan L, Stanley SE. A matter of priorities: High working memory enables (slightly) superior value-directed remembering. J Mem Lang. 2019 Oct 1;108:104032.

6. Murre JMJ, Dros J. Replication and Analysis of Ebbinghaus' Forgetting Curve. PLoS ONE [Internet]. 2015 Jul 6 [cited 2021 Apr 10];10(7). Available from: https://www.ncbi.nlm.nih.gov/pmc/articles/PMC4492928/

7. Feng K, Zhao X, Liu J, Cai Y, Ye Z, Chen C, et al. Spaced Learning Enhances Episodic Memory by Increasing Neural Pattern Similarity Across Repetitions. J Neurosci Off J Soc Neurosci. 2019 Jul 3;39(27):5351-60.

8. Smolen P, Zhang Y, Byrne JH. The right time to learn: mechanisms and optimization of spaced learning. Nat Rev Neurosci. 2016 Feb;17(2):77-88.

9. Sisti HM, Glass AL, Shors TJ. Neurogenesis and the spacing effect: Learning over time enhances memory and the survival of new neurons. Learn Mem. 2007 May;14(5):368-75.

10. Pollard MA, Courage ML. Working memory capacity predicts effective multitasking. Comput Hum Behav. 2017 Nov 1;76:450-62.

11. Arabacı G, Parris BA. Inattention and task switching performance: the role of predictability, working memory load and goal neglect. Psychol Res. 2020;84(8):2090-110.

12. Emerson MJ, Miyake A. The role of inner speech in task switching: A dual-task investigation. J Mem 
Lang. 2003 Jan 1;48(1):148-68.

13. Walck-Shannon EM, Rowell SF, Frey RF. To What Extent Do Study Habits Relate to Performance? CBE-Life Sci Educ. 2021 Jan 14;20(1):ar6.

14. Tomanek D, Montplaisir L. Students' Studying and Approaches to Learning in Introductory Biology. Cell Biol Educ. 2004 Dec 1;3(4):253-62.

15. Geller J, Toftness A, Carpenter P, Manz C, Coffman C, Lamm M. Study strategies and beliefs about learning as a function of academic achievement and achievement goals. Memory. 2017 Nov 3;26:1-9.

16. Yip M. Differences in Learning and Study Strategies between High and Low Achieving University Students: A Hong Kong study. Educ Psychol - EDUC PSYCHOL-UK. 2007 Oct 1;27:597-606.

17. Pace R, Pluye P, Bartlett G, Macaulay AC, Salsberg J, Jagosh J, et al. Testing the reliability and efficiency of the pilot Mixed Methods Appraisal Tool (MMAT) for systematic mixed studies review. Int J Nurs Stud. 2012 Jan 1;49(1):47-53.

18. Hong QN, Gonzalez-Reyes A, Pluye P. Improving the usefulness of a tool for appraising the quality of qualitative, quantitative and mixed methods studies, the Mixed Methods Appraisal Tool (MMAT). J Eval Clin Pract. 2018;24(3):459-67.

19. Alkhateeb HM, Nasser R. Assessment of Learning and Study Strategies of University Students in Qatar Using an Arabic Translation of the Learning and Study Strategies Inventory. Psychol Rep. 2014 Jun 1;114(3):947-65.

20. Senko C, Hama H, Belmonte K. Achievement goals, study strategies, and achievement: A test of the "learning agenda" framework. Learn Individ Differ. 2013 Apr 1;24:1-10.

21. Albaili MA. Differences Among Low ${ }^{-}$, Average- and High-achieving College Students on Learning and Study Strategies. Educ Psychol. 1997 Mar 1;17(1-2):171-7.

22. Dill AL, Justice CA, Minchew SS, Moran LM, Wang C, Weed CB. The Use of the LASSI (The Learning and Study Strategies Inventory) to Predict and Evaluate the Study Habits and Academic Performance of Students in a Learning Assistance Program. J Coll Read Learn. 2014 Jul 3;45(1):20-34.

23. Dobson JL. Learning style preferences and course performance in an undergraduate physiology class. Adv Physiol Educ. 2009 Dec;33(4):308-14.

24. Hartwig MK, Dunlosky J. Study strategies of college students: Are self-testing and scheduling related to achievement? Psychon Bull Rev. 2012 Feb 1;19(1):126-34.

25. Brown D. An evidence-based analysis of learning practices: the need for pharmacy students to employ more effective study strategies. Curr Pharm Teach Learn. 2017 Apr;9(2):163-70.

26. Sebesta AJ, Bray Speth E. How Should I Study for the Exam? Self-Regulated Learning Strategies and Achievement in Introductory Biology. CBE Life Sci Educ [Internet]. 2017 [cited $2021 \mathrm{Apr}$ 6];16(2). Available from: https://www.ncbi.nlm.nih.gov/pmc/articles/PMC5459248/

27. Stunden A, Jefferies D. The effectiveness of short answers test papers in evaluating academic nursing programs: A review of the literature. Nurse Educ Pract. 2018 Nov 1;33:94-101.

28. Dunlosky J. Strengthening the Student Toolbox: Study Strategies to Boost Learning. Am Educ. 2013;37(3):12-21.

29. Elliot A, McGregor H, Gable S, Gable S. Achievement goals, study strategies, and exam performance: A mediational analysis. J Educ Psychol. 1999;91:549.

30. Nonis SA, Hudson GI. Performance of College Students: Impact of Study Time and Study Habits. J Educ Bus. 2010 Mar 19;85(4):229-38.

31. Hoskins TD, Gantz JD, Chaffee BR, Arlinghaus K, Wiebler J, Hughes M, et al. Effectiveness of a Low-Cost, Graduate Student-Led Intervention on Study Habits and Performance in Introductory Biology. CBE Life Sci Educ. 2017;16(3).

32. Karpicke JD, Blunt JR. Retrieval practice produces more learning than elaborative studying with concept mapping. Science. 2011 Feb 11;331(6018):772-5.

33. Dowd JE, Duncan T, Reynolds JA. Concept Maps for Improved Science Reasoning and Writing: Complexity Isn’t Everything. CBE Life Sci Educ [Internet]. 2015 Dec 1 [cited 2021 Apr 10];14(4). 
Available from: https://www.ncbi.nlm.nih.gov/pmc/articles/PMC4710400/

34. Carr-Lopez SM, Galal SM, Vyas D, Patel RA, Gnesa EH. The Utility of Concept Maps to Facilitate Higher-Level Learning in a Large Classroom Setting. Am J Pharm Educ [Internet]. 2014 Nov 15 [cited 2021 Apr 10];78(9). Available from: https://www.ncbi.nlm.nih.gov/pmc/articles/PMC4453086/

35. Slieman TA, Camarata T. Case-Based Group Learning Using Concept Maps to Achieve Multiple Educational Objectives and Behavioral Outcomes. J Med Educ Curric Dev [Internet]. 2019 Sep 3 [cited 2021 Apr 10];6. Available from: https://www.ncbi.nlm.nih.gov/pmc/articles/PMC6724483/

36. Broekkamp H, Van Hout-Wolters BHAM. Students' Adaptation of Study Strategies When Preparing for Classroom Tests. Educ Psychol Rev. 2006 Sep 20;19(4):401.

37. Laight DW. Attitudes to concept maps as a teaching/learning activity in undergraduate health professional education: influence of preferred learning style. Med Teach. 2004 May;26(3):229-33.

38. Baig M, Tariq S, Rehman R, Ali S, Gazzaz ZJ. Concept mapping improves academic performance in problem solving questions in biochemistry subject. Pak J Med Sci. 2016;32(4):801-5.

39. Balasubramaniam G, K I. A Study of Learning Style Preferences among First Year Undergraduate Medical Students Using VARK Model. Educ Med J [Internet]. 2016 Dec 29 [cited 2021 Apr 4];8(4). Available from: http://eduimed.usm.my/EIMJ20160804/EIMJ20160804_03.pdf

40. Willman S, Linden R, Kaila E, Rajala T, Laakso MJ, Salakoski T. On study habits on an introductory course on programming. Computer Science Education. 2015 Aug 10 [cited 2021 Apr 4];25(3):276-291.

41. Husmann P, O'Loughlin VD. Another nail in the coffin for learning styles? Disparities among undergraduate anatomy students' study strategies, class performance, and reported VARK learning styles. Anat Sci Educ. 2018 March 13 [cited 2021 Apr 4];12(1):6-19.

42. O’Mahony S, Sbayeh A, Horgan M, O'Flynn S, O'Tuathaigh CMP. Association between learning style preferences and anatomy assessment outcomes in graduate-entry and undergraduate medical students. Anat Sci Educ. 2016 Feb 4;9(4):391-399.

43. Yip M. Differences between high and low academic achieving university students in learning and study strategies: a further investigation. Educ Res Eval. 2009 Dec 7;15(6):561-570.

44. Yip M. Relation of study strategies to the academic performance of Hong Kong university students. Psychol Rep. 2002 Feb 1;90(1):338-340.

45. Overwalle FV, Metsenaere MD. The effects of attribution-based intervention and study strategy training on academic achievement in college freshmen. Br J Educ Psychol. 1990 Nov;60(3):299-311.

\section{DECLARATIONS}

Funding: This systematic review was funded in part by a grant from The Duke of Edinburgh's International Award through the P2P program and in partnership with the federal government of Canada.

\section{Conflicts of interest/Competing interests:}

The authors declared no potential conflicts of interest with respect to the research, authorship, and/or publication of this article.

\section{Availability of data and material:}

N/A

\section{Code availability:}


N/A

\section{Authors' contributions:}

JX devised and supervised the project and secured funding acquisition. JO, TT, YK, AW, MV, and $\mathrm{HH}$ wrote the manuscript. JO created figures. TT, YK, and JO computed numerical data and created tables. JO and MV performed the article screening. AW, TT and YK performed hand searches. TT and YK carried out the quality assessment. All authors refined and approved the manuscript.

Appendix 1 - Database Searches

\begin{tabular}{|l|l|l|}
\hline Database & Search & Results \\
\hline PsychInfo (1967 - 2020) by Ovid & $\begin{array}{l}\text { (study strat* AND student*) OR (study strat* AND } \\
\text { achievement) }\end{array}$ & 109 \\
\hline Web of Science & $\begin{array}{l}\text { (study strat* AND student*) OR (study strat* AND } \\
\text { achievement) }\end{array}$ & 188 \\
\hline ProQuest & $\begin{array}{l}\text { (study strat* AND student*) OR (study strat* AND } \\
\text { achievement) }\end{array}$ & 184 \\
\hline
\end{tabular}

Appendix 2 - Grey Literature Searches

\begin{tabular}{|l|l|l|}
\hline Database & Search & Results \\
\hline $\begin{array}{l}\text { OpenGrey, Harvard Graduate } \\
\text { School of Education }\end{array}$ & $\begin{array}{l}\text { (study strat* AND student*) OR (study strat* AND } \\
\text { achievement) }\end{array}$ & 63 \\
\hline
\end{tabular}

\section{Appendix 3 - List of Excluded Studies}

Excluded articles from database abstract screen

\begin{tabular}{|l|l|}
\hline Author(s) & $\underline{\text { Title }}$ \\
\hline $\begin{array}{l}\text { A. B. Abdelkarim, Named } \\
\text { Hamadain, Elgenaid Tucci, } \\
\text { Michelle Ford, Timothy } \\
\text { Sullivan, Donna }\end{array}$ & $\begin{array}{l}\text { US dental students' and faculty members' attitudes about technology, } \\
\text { instructional strategies, student diversity, and school duration: A comparative } \\
\text { study }\end{array}$ \\
\hline $\begin{array}{l}\text { A. B. Qureshi, Syed Akhtar } \\
\text { Hussain Pirvani, Madiha } \\
\text { Dawani, Narendar }\end{array}$ & $\begin{array}{l}\text { Understanding and practice of evidence based search strategy among } \\
\text { postgraduate dental students: A preliminary study }\end{array}$ \\
\hline A. Blewitt & $\begin{array}{l}\text { Math and science academy literacy instruction: Student study strategies, } \\
\text { self-perception as readers, and reading achievement }\end{array}$ \\
\hline A. D. Arthur & $\begin{array}{l}\text { Differences between EDPSY 100 and non-EDPSY 100 students on study } \\
\text { skills as measured by the learning and study strategies inventory (LASSI) }\end{array}$ \\
\hline
\end{tabular}




\begin{tabular}{|c|c|}
\hline $\begin{array}{l}\text { A. E. Enns, Gloria D. } \\
\text { Montgomery, Cynthia Gonzalez, } \\
\text { Vivian M. }\end{array}$ & $\begin{array}{l}\text { Perceived stress, coping strategies, and emotional intelligence: A } \\
\text { cross-sectional study of university students in helping disciplines }\end{array}$ \\
\hline A. G. Caspi, P. Privman, M. & $\begin{array}{l}\text { Viewing comprehension: Students' learning preferences and strategies when } \\
\text { studying from video }\end{array}$ \\
\hline A. Halbach & $\begin{array}{l}\text { Finding Out About Students' Learning Strategies by Looking at Their Diaries: } \\
\text { A Case Study }\end{array}$ \\
\hline $\begin{array}{l}\text { A. J. H. Holm, Hannah Rhodes, } \\
\text { Matthew G. }\end{array}$ & $\begin{array}{l}\text { Study strategies and "study drugs": Investigating the relationship between } \\
\text { college students' study behaviors and prescription stimulant misuse }\end{array}$ \\
\hline A. J. S. Onwuegbuzie, C. R. & $\begin{array}{l}\text { Relations between hope and graduate students' coping strategies for studying } \\
\text { and examination-taking }\end{array}$ \\
\hline A. K. Geçer & $\begin{array}{l}\text { A study on information search and commitment strategies on web } \\
\text { environment and internet usage self-efficacy beliefs of university students }\end{array}$ \\
\hline $\begin{array}{l}\text { A. L. Heikkilä, Kirsti Nieminen, } \\
\text { Juha Niemivirta, Markku }\end{array}$ & $\begin{array}{l}\text { Relations between teacher students' approaches to learning, cognitive and } \\
\text { attributional strategies, well-being, and study success }\end{array}$ \\
\hline A. L. Loranger & The study strategies of successful and unsuccessful high school students \\
\hline A. M. Ager, M. & $\begin{array}{l}\text { Psychometric properties of the coping strategy indicator (CSI) in a study of } \\
\text { coping behaviour amongst Malawian students }\end{array}$ \\
\hline $\begin{array}{l}\text { A. M. Francis-Cracknell, Shari } \\
\text { Kent, Fiona Edwards, Emma } \\
\text { Iles, Ross }\end{array}$ & $\begin{array}{l}\text { Several strategies for clinical partners and universities are perceived to } \\
\text { enhance physiotherapy student engagement in non-metropolitan clinical } \\
\text { placements: a mixed-methods study }\end{array}$ \\
\hline $\begin{array}{l}\text { A. M. Rogiers, Emmelien Van } \\
\text { Keer, Hilde }\end{array}$ & $\begin{array}{l}\text { What they say is what they do? Comparing task-specific self-reports, } \\
\text { think-aloud protocols, and study traces for measuring secondary school } \\
\text { students' text-learning strategies }\end{array}$ \\
\hline A. M. S.-R. Navea-Martin, Jose & Study on the use of self-motivational strategies in university students \\
\hline A. M.-U. Schwed, Janice & $\begin{array}{l}\text { Brain-friendly study strategies, Grades 2-8: How teachers can help students } \\
\text { learn }\end{array}$ \\
\hline $\begin{array}{l}\text { A. P. Brugnolli, Serena Viviani, } \\
\text { Debora Saiani, Luisa }\end{array}$ & $\begin{array}{l}\text { Nursing students' perceptions of tutorial strategies during clinical learning } \\
\text { instruction: A descriptive study }\end{array}$ \\
\hline $\begin{array}{l}\text { A. P. Reaser, Frances Petscher, } \\
\text { Yaacov Proctor, Briley }\end{array}$ & The learning and study strategies of college students with ADHD \\
\hline $\begin{array}{l}\text { A. R. D. Daros, Katharine E. } \\
\text { Meyer, M. Joseph Chow, Philip } \\
\text { I. Barnes, Laura E. Teachman, } \\
\text { Bethany A. }\end{array}$ & $\begin{array}{l}\text { Impact of social anxiety and social context on college students' emotion } \\
\text { regulation strategy use: An experience sampling study }\end{array}$ \\
\hline A. Raimes & $\begin{array}{l}\text { Language proficiency, writing ability, and composing strategies: A study of } \\
\text { ESL college student writers }\end{array}$ \\
\hline B. B. S. Silver, Everett V., Jr. & A study strategies self-efficacy instrument for use with community college \\
\hline
\end{tabular}




\begin{tabular}{|c|c|}
\hline Greene, Barbara A. & students \\
\hline B. K. S. Matin, Shahin & $\begin{array}{l}\text { Comment on "coping strategy mediates the relationship between body image } \\
\text { evaluation and mental health: A study with Chinese college students with } \\
\text { disabilities" }\end{array}$ \\
\hline $\begin{array}{l}\text { B. R. B. Schirmer, J. Lockman, } \\
\text { A. S. }\end{array}$ & $\begin{array}{l}\text { What verbal protocols reveal about the reading strategies of deaf students: A } \\
\text { replication study }\end{array}$ \\
\hline B. S. B. Olaussen, Ivar & $\begin{array}{l}\text { Identifying latent variables measured by the Learning and Study Strategies } \\
\text { Inventory (LASSI) in Norwegian college students }\end{array}$ \\
\hline B. W. Tuckman & The "Strategies-for-Achievement" Approach for Teaching Study Skills \\
\hline $\begin{array}{l}\text { C. A. B. Orsini, Vivian I. Tricio, } \\
\text { Jorge A. }\end{array}$ & $\begin{array}{l}\text { Motivational profiles and their relationships with basic psychological needs, } \\
\text { academic performance, study strategies, self-esteem, and vitality in dental } \\
\text { students in Chile }\end{array}$ \\
\hline C. B. Darnon, Fabrizio & $\begin{array}{l}\text { Achievement goals, study strategies, and intrinsic motivation: presentation of } \\
\text { a research field and validation of the French version of Elliot and McGregor's } \\
\text { (2001) scale }\end{array}$ \\
\hline C. Badenier & $\begin{array}{l}\text { Reliability and validity of the Learning and Study Strategies Inventory } \\
\text { (LASSI) in a sample of students from the metropolitan region in Chile }\end{array}$ \\
\hline $\begin{array}{l}\text { C. C.-F. Wei-Po, Yen Tai-Ling, } \\
\text { Liu }\end{array}$ & $\begin{array}{l}\text { Predicting effects of psychological inflexibility/experiential avoidance and } \\
\text { stress coping strategies for internet addiction, significant depression, and } \\
\text { suicidality in college students: A prospective study }\end{array}$ \\
\hline $\begin{array}{l}\text { C. D. B. Meneghetti, Rossana } \\
\text { Cornoldi, Cesare }\end{array}$ & $\begin{array}{l}\text { Strategic knowledge and consistency in students with good and poor study } \\
\text { skills }\end{array}$ \\
\hline C. F. Russo & $\begin{array}{l}\text { A comparative study of creativity and cognitive problem-solving strategies of } \\
\text { high-IQ and average students }\end{array}$ \\
\hline C. I. A. Ioannou, Eckart & $\begin{array}{l}\text { Approaches to and treatment strategies for playing-related pain problems } \\
\text { among Czech instrumental music students }\end{array}$ \\
\hline $\begin{array}{l}\text { C. I. Andrei, Varga Patricia } \\
\text { Valentina, Zetes }\end{array}$ & $\begin{array}{l}\text { Comparative study between study tracks: math and sciences or humanities, } \\
\text { regarding acadesmic motivation and learning strategies in the 9th grade } \\
\text { students }\end{array}$ \\
\hline $\begin{array}{l}\text { C. M. K. Kokkinos, Apostolos } \\
\text { Markos, Angelos }\end{array}$ & $\begin{array}{l}\text { The relationship between learning and study strategies and big five personality } \\
\text { traits among junior university student teachers }\end{array}$ \\
\hline D. A. Kahn & $\begin{array}{l}\text { Predicting math achievement using the SMALSI as a measure of motivation } \\
\text { and learning and study strategy use }\end{array}$ \\
\hline $\begin{array}{l}\text { D. C. Kim Josefina Hubertina, } \\
\text { Gino Kester, Liesbeth Kirschner, } \\
\text { Paul Arthur }\end{array}$ & $\begin{array}{l}\text { Do secondary school students make use of effective study strategies when } \\
\text { they study on their own? }\end{array}$ \\
\hline $\begin{array}{l}\text { D. C. T. Beidel, S. M. } \\
\text { Taylor-Ferreira, J. C. }\end{array}$ & $\begin{array}{l}\text { Teaching study skills and test-taking strategies to elementary school students - } \\
\text { The testbusters program }\end{array}$ \\
\hline
\end{tabular}




\begin{tabular}{|c|c|}
\hline D. D. Shukla, Aj Pattaradanai & $\begin{array}{l}\text { Student's perceived level and teachers' teaching strategies of higher order } \\
\text { thinking skills: A study on higher educational institutions in thailand }\end{array}$ \\
\hline D. K. Harless & $\begin{array}{l}\text { A comparison of gender differences in the relationship among learning styles, } \\
\text { achieving styles and study strategies of college students }\end{array}$ \\
\hline $\begin{array}{l}\text { D. L. E. Butler, Cory L. Poole, } \\
\text { Shannon }\end{array}$ & $\begin{array}{l}\text { Promoting strategic writing by postsecondary students with learning } \\
\text { disabilities: A report of three case studies }\end{array}$ \\
\hline D. S.-L. Rodger, Adele & Students' perceptions of debating as a learning strategy: A qualitative study \\
\hline $\begin{array}{l}\text { D. Z. Zhao, Huaqian Wu, Yingli } \\
\text { Zhou, Qianfu }\end{array}$ & $\begin{array}{l}\text { A study of the impact of internet-based instruction integrated innovation } \\
\text { education on university student entrepreneurial team collaboration and } \\
\text { strategic innovation }\end{array}$ \\
\hline $\begin{array}{l}\text { E. D. Boujut, Annika Grouselle, } \\
\text { Amelie Cappe, Emilie }\end{array}$ & $\begin{array}{l}\text { Comparative study of teachers in regular schools and teachers in specialized } \\
\text { schools in france, working with students with an autism spectrum disorder: } \\
\text { Stress, social support, coping strategies and burnout }\end{array}$ \\
\hline $\begin{array}{l}\text { E. D. Kissi, Kwaku Ahadzie } \\
\text { Debrah, Caleb Adjei-Kumi, } \\
\text { Theophilus }\end{array}$ & $\begin{array}{l}\text { Underlying strategies for improving entrepreneurial skills development of } \\
\text { technical and vocational students in developing countries: using Ghana as a } \\
\text { case study }\end{array}$ \\
\hline $\begin{array}{l}\text { E. d. S. Boruchovitch, Acácia } \\
\text { Aparecida Angeli }\end{array}$ & Psychometric studies of the Learning Strategies Scale for university students \\
\hline $\begin{array}{l}\text { E. E. W. Hall, Resa E. Hall, } \\
\text { Katherine S. }\end{array}$ & $\begin{array}{l}\text { Weight loss strategies used by first year college students: An exploratory } \\
\text { study }\end{array}$ \\
\hline $\begin{array}{l}\text { E. G. E. Carayannis, Dan } \\
\text { Hanson, Mike }\end{array}$ & $\begin{array}{l}\text { A cross-cultural learning strategy for entrepreneurship education: Outline of } \\
\text { key concepts and lessons learned from a comparative study of } \\
\text { entrepreneurship students in France and the US }\end{array}$ \\
\hline $\begin{array}{l}\text { E. H. Bush, Karen Zickefoose, } \\
\text { Samantha Simanek, Gina } \\
\text { Holmberg, Michelle Henderson, } \\
\text { Ambyr }\end{array}$ & $\begin{array}{l}\text { Learning and study strategies of students with traumatic brain injury: A mixed } \\
\text { method study }\end{array}$ \\
\hline $\begin{array}{l}\text { E. H. Henderson, H. Grant, A. } \\
\text { Berlin, A. }\end{array}$ & $\begin{array}{l}\text { Conflict and coping strategies: a qualitative study of student attitudes to } \\
\text { significant event analysis }\end{array}$ \\
\hline E. T. P. Goetz, Douglas J. & $\begin{array}{l}\text { The role of students' perceptions of study strategy and personal attributes in } \\
\text { strategy use }\end{array}$ \\
\hline E. Y. Sendurur, Zahide & $\begin{array}{l}\text { Students' web search strategies with different task types: An eye-tracking } \\
\text { study }\end{array}$ \\
\hline F. C. Lv, Hongxin & $\begin{array}{l}\text { A study of metacognitive-strategies-based writing instruction for vocational } \\
\text { college students }\end{array}$ \\
\hline F. J. Sinkavich & $\begin{array}{l}\text { Metamemory, attributional style, and study strategies: Predicting classroom } \\
\text { performance in graduate students }\end{array}$ \\
\hline $\begin{array}{l}\text { F. R. R. Croft, P. Larueatuonah, } \\
\text { S. Baechle, C. Gemmill, J. }\end{array}$ & $\begin{array}{l}\text { Pilot investigation of validation of the modified learning and study strategies } \\
\text { inventory (LASSI) for hearing-impaired preparatory students at Gallaudet }\end{array}$ \\
\hline
\end{tabular}




\begin{tabular}{|c|c|}
\hline & university \\
\hline F. Shaghaghi & $\begin{array}{l}\text { Comparing the study methods of Iranian and American high school students } \\
\text { from the perspective of cognitive and metacognitive strategies }\end{array}$ \\
\hline $\begin{array}{l}\text { F.-F. L. Zhao, Xiao-Ling He, } \\
\text { Wei Gu, Yan-Hong Li, } \\
\text { Dong-Wen }\end{array}$ & $\begin{array}{l}\text { The study of perceived stress, coping strategy and self-efficacy of Chinese } \\
\text { undergraduate nursing students in clinical practice }\end{array}$ \\
\hline G. B. Kim, Jiyoung & $\begin{array}{l}\text { A study into students' use of digital english learning strategies in tertiary } \\
\text { education }\end{array}$ \\
\hline $\begin{array}{l}\text { G. M. M. Boulton-lewis, } \\
\text { Ference Lewis, David C. Wilss, } \\
\text { Lynn A. }\end{array}$ & $\begin{array}{l}\text { A longitudinal study of learning for a group of indigenous Australian } \\
\text { university students: Dissonant conceptions and strategies }\end{array}$ \\
\hline G. Zhao & $\begin{array}{l}\text { A cross-cultural study on the conflict management strategies between chinese } \\
\text { and american college students }\end{array}$ \\
\hline $\begin{array}{l}\text { H. A.-S. Laine, Vera Haukkala, } \\
\text { Ari Hankonen, Nelli }\end{array}$ & $\begin{array}{l}\text { Acceptability of strategies to reduce student sitting: A mixed-methods study } \\
\text { with college teachers }\end{array}$ \\
\hline H. B. S. Sheu, W. E. & $\begin{array}{l}\text { An exploratory study of help-seeking attitudes and coping strategies among } \\
\text { college students by race and gender }\end{array}$ \\
\hline $\begin{array}{l}\text { H. B. Weber, Dominik Hillmert, } \\
\text { Steffen }\end{array}$ & $\begin{array}{l}\text { Information-seeking behaviour and academic success in higher education: } \\
\text { Which search strategies matter for grade differences among university } \\
\text { students and how does this relevance differ by field of study? }\end{array}$ \\
\hline $\begin{array}{l}\text { H. M. A.-M. Al-Kadri, } \\
\text { Mohamed S. Al-Takroni, Habib } \\
\text { Roberts, Chris van der Vleuten, } \\
\text { Cees P. M. }\end{array}$ & $\begin{array}{l}\text { Self-assessment and students' study strategies in a community of clinical } \\
\text { practice: A qualitative study }\end{array}$ \\
\hline $\begin{array}{l}\text { H. M. A.-m. Al-Kadri, } \\
\text { Mohamed S. Roberts, Chris Van } \\
\text { der vleuten, Cees P. }\end{array}$ & $\begin{array}{l}\text { Exploring assessment factors contributing to students' study strategies: } \\
\text { Literature review }\end{array}$ \\
\hline $\begin{array}{l}\text { H. P. Yang, Xiaoping Zheng, Bo } \\
\text { Wang, Linxian Wang, Yadong } \\
\text { Du, Shuai Lu, Xinyi }\end{array}$ & $\begin{array}{l}\text { A strategy study on risk communication of pandemic influenza: A mental } \\
\text { model study of college students in Beijing }\end{array}$ \\
\hline H. Sueki & $\begin{array}{l}\text { Preferences for suicide prevention strategies among university students in } \\
\text { Japan: a cross-sectional study using full-profile conjoint analysis }\end{array}$ \\
\hline H.-B. S. Sheu, William E. & $\begin{array}{l}\text { An exploratory study of help-seeking attitudes and coping strategies among } \\
\text { college students by race and gender }\end{array}$ \\
\hline I. Jackson & $\begin{array}{l}\text { Development of a strategic framework for addressing the needs of students } \\
\text { with disabilities in Sydney catholic schools (case study) }\end{array}$ \\
\hline I. R. Alqarni & $\begin{array}{l}\text { Saudi english major freshmen students' vocabulary learning strategies: an } \\
\text { exploratory study }\end{array}$ \\
\hline J. A. Subramanian, V. R. & Improving the quality of educational strategies in postgraduate dental \\
\hline
\end{tabular}




\begin{tabular}{|c|c|}
\hline $\begin{array}{l}\text { Morgaine, K. C. Thomson, W. } \\
\text { M. }\end{array}$ & $\begin{array}{l}\text { education using student and graduate feedback: findings from a qualitative } \\
\text { study in New Zealand }\end{array}$ \\
\hline J. B. Rankin, Val & $\begin{array}{l}\text { brain-friendly study strategies, Grades 2-8: How teachers can help students } \\
\text { learn }\end{array}$ \\
\hline J. B. Rankin, Val & $\begin{array}{l}\text { Creative teaching method as a learning strategy for student midwives: A } \\
\text { qualitative study }\end{array}$ \\
\hline J. Bolden & $\begin{array}{l}\text { Associations among attention problems, learning strategies, and hazardous } \\
\text { drinking behavior in a college student sample: A pilot study }\end{array}$ \\
\hline J. C. King Ebrahimian & $\begin{array}{l}\text { The effect of study skills instruction on the study strategies and attitudes of } \\
\text { college students with learning disabilities }\end{array}$ \\
\hline $\begin{array}{l}\text { J. C. M. Turner, C. Meyer, D. K. } \\
\text { Gheen, M. Anderman, E. M. } \\
\text { Kang, Y. Patrick, H. }\end{array}$ & $\begin{array}{l}\text { The classroom environment and students' reports of avoidance strategies in } \\
\text { mathematics: A multimethod study }\end{array}$ \\
\hline J. E. J. Ormrod, Lynn & $\begin{array}{l}\text { Study strategies for learning spelling: Correlations with achievement and } \\
\text { developmental changes }\end{array}$ \\
\hline $\begin{array}{l}\text { J. H. Kuo, Chris Miller, Michael } \\
\text { T. }\end{array}$ & $\begin{array}{l}\text { Encouraging college student success: The instructional challenges, response } \\
\text { strategies, and study skills of contemporary undergraduates }\end{array}$ \\
\hline $\begin{array}{l}\text { J. J. Malmberg, Hanna Jarvela, } \\
\text { Sanna }\end{array}$ & $\begin{array}{l}\text { Tracing elementary school students' study tactic use in study by examining a } \\
\text { strategic and self-regulated learning }\end{array}$ \\
\hline J. J. P. B. Le Grange, Karel F. H. & $\begin{array}{l}\text { The behavioural self-regulation strategies of Indian South African university } \\
\text { students: An exploratory study }\end{array}$ \\
\hline J. Jarvis & $\begin{array}{l}\text { 'Study in Estonia': the strategic implications of hosting international students } \\
\text { on Estonia's tourism economy }\end{array}$ \\
\hline $\begin{array}{l}\text { J. K. P. Corkett, Rauno Hein, } \\
\text { Serge F. }\end{array}$ & $\begin{array}{l}\text { Learning and study strategies of university students who report a significant } \\
\text { history of reading difficulties }\end{array}$ \\
\hline J. L. Han, Qingsheng & $\begin{array}{l}\text { A correlation study among achievement motivation, goal-setting and L2 } \\
\text { learning strategy in EFL context }\end{array}$ \\
\hline J. L. Vacek, Judy & $\begin{array}{l}\text { Teaching concepts to nursing students using model case studies, the venn } \\
\text { diagram, and questioning strategies }\end{array}$ \\
\hline $\begin{array}{l}\text { J. L.-K. Chwaszcz, Bernadeta } \\
\text { Wiechetek, Michal } \\
\text { Niewiadomska, Iwona } \\
\text { Palacz-Chrisidis, Agnieszka }\end{array}$ & $\begin{array}{l}\text { Personality traits, strategies for coping with stress and the level of internet } \\
\text { addiction: A study of Polish secondary-school students }\end{array}$ \\
\hline $\begin{array}{l}\text { J. M. H. Williams, Kal } \\
\text { Marcavage, Emily }\end{array}$ & $\begin{array}{l}\text { Experimental study of assertion training as a drug prevention strategy for use } \\
\text { with college students }\end{array}$ \\
\hline J. M. M. Monteil, N. & $\begin{array}{l}\text { Effects of context and performance feedback on social comparison strategies } \\
\text { among low-achievement students: experimental studies }\end{array}$ \\
\hline J. N. C. Erin, Anne L. Wolffe, & Learning and study strategies of secondary school students with visual \\
\hline
\end{tabular}




\begin{tabular}{|c|c|}
\hline Karen & impairments \\
\hline J. P. C. Szlachta & $\begin{array}{l}\text { Peer instruction of first-year nurse anesthetist students: A pilot study of a } \\
\text { strategy to use limited faculty resources and promote earning }\end{array}$ \\
\hline J. P. Cioffi, N. Arundell, F. & $\begin{array}{l}\text { A pilot study to investigate the effect of a simulation strategy on the clinical } \\
\text { decision making of midwifery students }\end{array}$ \\
\hline J. Park & $\begin{array}{l}\text { The effects of perceived environmental factors and adolescents' motivation on } \\
\text { achievement mediated through study strategy in the United States and Korea. } \\
\text { (family value orientation, ego orientation, high school students) }\end{array}$ \\
\hline $\begin{array}{l}\text { J. R. Roca, Mercedes Canet, } \\
\text { Olga }\end{array}$ & $\begin{array}{l}\text { Learning outcomes of "The Oncology Patient" study among nursing students: } \\
\text { A comparison of teaching strategies }\end{array}$ \\
\hline $\begin{array}{l}\text { J. R. S. Kirby, Robert } \\
\text { Allingham, Beth H. Parrila, } \\
\text { Rauno La Fave, Chantal B. }\end{array}$ & $\begin{array}{l}\text { Learning strategies and study approaches of postsecondary students with } \\
\text { dyslexia }\end{array}$ \\
\hline $\begin{array}{l}\text { J. S. Nijhuis, Mien Gijselaers, } \\
\text { Wim }\end{array}$ & $\begin{array}{l}\text { The interplay of perceptions of the learning environment, personality and } \\
\text { learning strategies: a study amongst International Business Studies students }\end{array}$ \\
\hline J. S. Oh, Lorraine & $\begin{array}{l}\text { Nursing students' preferences of strategies surrounding cinenurducation in a } \\
\text { first year child growth and development courses: A mixed methods study }\end{array}$ \\
\hline $\begin{array}{l}\text { J. S. S. Krajcik, Patricia E. } \\
\text { Lunetta, Vincent N. }\end{array}$ & $\begin{array}{l}\text { A research strategy for the dynamic study of students' concepts and problem } \\
\text { solving strategies using science software }\end{array}$ \\
\hline J. Swafford & Comprehension strategies research and college developmental studies students \\
\hline J. Szlachta & $\begin{array}{l}\text { Peer instruction of first-year nurse anesthetist students: A pilot study of a } \\
\text { strategy to use limited faculty resources and promote learning }\end{array}$ \\
\hline J.-Y. W. Pan, Daniel Fu Keung & $\begin{array}{l}\text { Acculturative stressors and acculturative strategies as predictors of negative } \\
\text { affect among Chinese international students in Australia and Hong Kong: A } \\
\text { cross-cultural comparative study }\end{array}$ \\
\hline K. Bippert & $\begin{array}{l}\text { Text engagement \& reading strategy use: A case study of four early adolescent } \\
\text { students }\end{array}$ \\
\hline K. F. L. Hew, Chung Kwan & $\begin{array}{l}\text { Comparing video styles and study strategies during video-recorded lectures: } \\
\text { Effects on secondary school mathematics students' preference and learning }\end{array}$ \\
\hline $\begin{array}{l}\text { K. J. H. C. Dirkx, Gino Kester, } \\
\text { Liesbeth Kirschner, Paul Arthur }\end{array}$ & $\begin{array}{l}\text { Do secondary school students make use of effective study strategies when } \\
\text { they study on their own? }\end{array}$ \\
\hline $\begin{array}{l}\text { K. J. P. M. S. B. Suda, Gillian C. } \\
\text { PharmD Franks, Andrea S. } \\
\text { PharmD }\end{array}$ & Faculty and student perceptions of effective study strategies and materials \\
\hline K. K. Howard, Brian & Study tours: Strategies for serving business students \\
\hline K. L. Hong-Nam, Alexandra G. & $\begin{array}{l}\text { A comparative study of language learning strategy use in an EFL context: } \\
\text { monolingual korean and bilingual Korean-Chinese university students }\end{array}$ \\
\hline
\end{tabular}




\begin{tabular}{|c|c|}
\hline K. L. Lueg, Rainer & $\begin{array}{l}\text { Why do students choose English as a medium of instruction? A Bourdieusian } \\
\text { perspective on the study strategies of non-native English speakers }\end{array}$ \\
\hline K. M. Scully, Miguel & $\begin{array}{l}\text { Peer influence strategies in collectively consumed products (events and } \\
\text { festivals): An exploratory study among university students }\end{array}$ \\
\hline K. M. T. O. Collins, A. J. & $\begin{array}{l}\text { Study coping and examination-taking coping strategies: the role of learning } \\
\text { modalities among female graduate students }\end{array}$ \\
\hline K. N. Salmela-Aro, Jari-Erik & $\begin{array}{l}\text { Achievement and social strategies during university studies and career } \\
\text { characteristics } 10 \text { year later }\end{array}$ \\
\hline $\begin{array}{l}\text { K. R. Morehead, Matthew G. } \\
\text { DeLozier, Sarah }\end{array}$ & Instructor and student knowledge of study strategies \\
\hline K. S. Castleberry & $\begin{array}{l}\text { Rationale and research concerning pre reading study strategies with secondary } \\
\text { and college students }\end{array}$ \\
\hline $\begin{array}{l}\text { K. T. Salmela-Aro, Asko Nurmi, } \\
\text { Jari-Erik }\end{array}$ & $\begin{array}{l}\text { Achievement strategies during university studies predict early career burnout } \\
\text { and engagement }\end{array}$ \\
\hline K. W. Kovach, L. R. & $\begin{array}{l}\text { Learning and study strategies, and performance anxiety in postsecondary } \\
\text { students with learning disabilities: A preliminary study }\end{array}$ \\
\hline $\begin{array}{l}\text { K. W. Sutthinaraphan, } \\
\text { Punchalee }\end{array}$ & $\begin{array}{l}\text { A study of english communication strategy use of undergraduate students } \\
\text { majoring in science }\end{array}$ \\
\hline $\begin{array}{l}\text { L. B. MacCullagh, Agnes } \\
\text { Badcock, Nicholas A. }\end{array}$ & $\begin{array}{l}\text { University students with dyslexia: A qualitative exploratory study of learning } \\
\text { practices, challenges and strategies }\end{array}$ \\
\hline $\begin{array}{l}\text { L. B. MacCullagh, Agnes } \\
\text { Badcock, Nicholas A. }\end{array}$ & $\begin{array}{l}\text { University students with dyslexia: A qualitative exploratory study of learning } \\
\text { practices, challenges and strategies }\end{array}$ \\
\hline L. B. S. Bliss, Janice R. & $\begin{array}{l}\text { The effects of institutional culture on study strategies of hispanic students as } \\
\text { measured by the inventario de comportamiento de estudio, the spanish version } \\
\text { of the study behavior inventory }\end{array}$ \\
\hline L. C. Howell & $\begin{array}{l}\text { The effect of learning styles, preferred intelligence, and study strategies on a } \\
\text { student's preference for condensed or distributed instruction }\end{array}$ \\
\hline L. Cheng & $\begin{array}{l}\text { A study of Chinese engineering students' communication strategies in a } \\
\text { mobile-assisted professional development course }\end{array}$ \\
\hline L. G. Johnson, S. Harris, K. R. & $\begin{array}{l}\text { The effects of goal setting and self-instruction on learning a reading } \\
\text { comprehension strategy: A study of students with learning disabilities }\end{array}$ \\
\hline L. Hirsto & $\begin{array}{l}\text { Certainty of career choice at the beginning of university studies - general } \\
\text { strategies and attributions in achievement situations, and career motives }\end{array}$ \\
\hline $\begin{array}{l}\text { L. I. Wilhelmi, Freya } \\
\text { Steinhaeuser, Jost }\end{array}$ & $\begin{array}{l}\text { What leads to the subjective perception of a 'rural area'? A qualitative study } \\
\text { with undergraduate students and postgraduate trainees in Germany to tailor } \\
\text { strategies against physician's shortage }\end{array}$ \\
\hline $\begin{array}{l}\text { L. J. M.-P. Labrague, Denise M. } \\
\text { Papathanasiou, Ioanna V. Edet, }\end{array}$ & Stress and coping strategies among nursing students: an international study \\
\hline
\end{tabular}




\begin{tabular}{|c|c|}
\hline $\begin{array}{l}\text { Olaide B. Tsaras, Konstantinos } \\
\text { Leocadio, Michael C. Colet, } \\
\text { Paolo Kleisiaris, Christos F. } \\
\text { Fradelos, Evangelos C. Rosales, } \\
\text { Rheajane A. Vera Santos-Lucas, } \\
\text { Katherine Velacaria, Pearl Irish } \\
\text { T. }\end{array}$ & \\
\hline $\begin{array}{l}\text { L. K. G. Fryer, Paul Walker, } \\
\text { Richard }\end{array}$ & $\begin{array}{l}\text { Reciprocal modelling of Japanese university students' regulation strategies and } \\
\text { motivational deficits for studying }\end{array}$ \\
\hline $\begin{array}{l}\text { L. K.-Q. Anderson-Inman, } \\
\text { Carolyn Horney, Mark A. }\end{array}$ & $\begin{array}{l}\text { Computer-based study strategies for students with learning disabilities: } \\
\text { Individual differences associated with adoption level }\end{array}$ \\
\hline $\begin{array}{l}\text { L. L. Huang, Wansheng Xu, } \\
\text { Fuming Liu, Hairong Yu, Liang }\end{array}$ & $\begin{array}{l}\text { Emotional responses and coping strategies in nurses and nursing students } \\
\text { during Covid-19 outbreak: A comparative study }\end{array}$ \\
\hline L. L. Newman & $\begin{array}{l}\text { Test anxiety, study strategies, and exam performance in first year chiropractic } \\
\text { students }\end{array}$ \\
\hline $\begin{array}{l}\text { L. M.-M. Jimenez-Taracido, } \\
\text { Ana I. }\end{array}$ & $\begin{array}{l}\text { Do students apply the learning strategies they report? Study of reading } \\
\text { comprehension monitoring in scientific texts }\end{array}$ \\
\hline L. R. M. Royanto & $\begin{array}{l}\text { The effect of an intervention program based on scaffolding to improve } \\
\text { metacognitive strategies in reading: a study of year } 3 \text { elementary school } \\
\text { students in Jakarta }\end{array}$ \\
\hline $\begin{array}{l}\text { L. S. Westin, Annelie J. } \\
\text { Berglund, Mia }\end{array}$ & $\begin{array}{l}\text { Students' experiences of learning in relation to didactic strategies during the } \\
\text { first year of a nursing programme: a qualitative study }\end{array}$ \\
\hline $\begin{array}{l}\text { L. S. Wolf, Andrea Warner Ross, } \\
\text { Ratchneewan }\end{array}$ & $\begin{array}{l}\text { Predictors of stress and coping strategies of US accelerated vs. generic } \\
\text { baccalaureate nursing students: an embedded mixed methods study }\end{array}$ \\
\hline L. Z. Zou, Ye & $\begin{array}{l}\text { A study of english vocabulary learning strategies used by ethnic minority } \\
\text { students in leshan normal university, Sichuan, China }\end{array}$ \\
\hline M. A. D. Abulela, Earnest C., Jr. & $\begin{array}{l}\text { Measurement invariance of the Learning and Study Strategies } \\
\text { Inventory-second edition (LASSI-II) across gender and discipline in Egyptian } \\
\text { college students }\end{array}$ \\
\hline M. A. D. Casado, Mary I. & $\begin{array}{l}\text { Effect of educational strategies on anxiety in the second language classroom: } \\
\text { An exploratory comparative study between U.S. and Spanish first-semester } \\
\text { university students }\end{array}$ \\
\hline $\begin{array}{l}\text { M. B. Koopman, Anouke } \\
\text { Beijaard, Douwe }\end{array}$ & $\begin{array}{l}\text { Students' goal orientations and learning strategies in a powerful learning } \\
\text { environment: A case study }\end{array}$ \\
\hline $\begin{array}{l}\text { M. B. Tower, Eddie Watson, } \\
\text { Bernadette Heffernan, Catherine } \\
\text { Tronoff, Glenyss }\end{array}$ & $\begin{array}{l}\text { Using social media as a strategy to address 'sophomore slump' in second year } \\
\text { nursing students: A qualitative study }\end{array}$ \\
\hline M. C. W. C. Yip, Olive L. L. & $\begin{array}{l}\text { Relation of study strategies to the academic performance of Hong Kong } \\
\text { university students }\end{array}$ \\
\hline M. C. Yip & Differences in learning and study strategies between high and low achieving \\
\hline
\end{tabular}




\begin{tabular}{|c|c|}
\hline & university students: A Hong Kong study \\
\hline M. C. Yip & $\begin{array}{l}\text { Differences between high and low academic achieving university students in } \\
\text { learning and study strategies: A further investigation }\end{array}$ \\
\hline M. D. Samadi, Mehdi & $\begin{array}{l}\text { A case study of the predicting power of cognitive, metacognitive and } \\
\text { motivational strategies in girl students' achievements }\end{array}$ \\
\hline M. E. Brewster & $\begin{array}{l}\text { The effect of achievement motivation on fifth-grade students' choice of study } \\
\text { strategies }\end{array}$ \\
\hline M. E. G. Gredler, L. S. & $\begin{array}{l}\text { Students' perceptions of their self-regulatory and other-directed study } \\
\text { strategies: A factor analysis }\end{array}$ \\
\hline M. F. Rauch, Ceil & Motivating students to use newly learned study strategies \\
\hline M. Fitriana & $\begin{array}{l}\text { Students' reading strategies in comprehending academic reading: a case study } \\
\text { in an indonesian private college }\end{array}$ \\
\hline M. G. Gredler, L. & $\begin{array}{l}\text { Students' perceptions of their self-regulatory and other-directed study } \\
\text { strategies: A factor analysis }\end{array}$ \\
\hline M. G. L. Ge, J. & $\begin{array}{l}\text { Study on relationships between English learning strategies and academic } \\
\text { achievement of middle school students }\end{array}$ \\
\hline M. J. R. Khan, Seemab & $\begin{array}{l}\text { Moderating role of learning strategies between meta-cognitive awareness and } \\
\text { study habits among university students }\end{array}$ \\
\hline $\begin{array}{l}\text { M. K. O. Tallent-Runnels, } \\
\text { Arturo Lotven, Ann C. Walsh, } \\
\text { Sharon K. et al., }\end{array}$ & $\begin{array}{l}\text { A comparison of learning and study strategies of gifted and average-ability } \\
\text { junior high students }\end{array}$ \\
\hline $\begin{array}{l}\text { M. L. Wijnen, Sofie M. M. } \\
\text { Smeets, Guus Kroeze, Maarten } \\
\text { van der Molen, Henk }\end{array}$ & $\begin{array}{l}\text { Comparing problem-based learning students to students in a lecture-based } \\
\text { curriculum: learning strategies and the relation with self-study time }\end{array}$ \\
\hline M. M. K. Mitchell, C. M. & $\begin{array}{l}\text { Coping strategies used by occupational-therapy students during fieldwork: an } \\
\text { exploratory study }\end{array}$ \\
\hline $\begin{array}{l}\text { M. R. C. Ramos, Clare Reicher, } \\
\text { Stephen Haslam, S. Alexander }\end{array}$ & $\begin{array}{l}\text { A longitudinal study of the effects of discrimination on the acculturation } \\
\text { strategies of international students }\end{array}$ \\
\hline M. S. Emsaki, Shahla & $\begin{array}{l}\text { Comparative study of terminating conversation strategies used by graduate } \\
\text { TEFL students and graduate native English speaking students }\end{array}$ \\
\hline M. S. Samuelstuen & $\begin{array}{l}\text { Psychometric properties and item-keying direction effects for the Learning } \\
\text { and Study Strategies Inventory-High School Version with Norwegian students }\end{array}$ \\
\hline M. T. Prosser, Keith & $\begin{array}{l}\text { Student evaluations of teaching and courses: student study strategies as a } \\
\text { criterion of validity }\end{array}$ \\
\hline M. Tsuei & The study of peer-assisted learning strategy system for elementary students \\
\hline $\begin{array}{l}\text { M. Z. M. Z. Yusoff, Nor Azan } \\
\text { Mat }\end{array}$ & $\begin{array}{l}\text { Exploring suitable emotion-focused strategies in helping students to regulate } \\
\text { their emotional state in a tutoring system: Malaysian case study }\end{array}$ \\
\hline
\end{tabular}




\begin{tabular}{|c|c|}
\hline $\begin{array}{l}\text { N. I. Abouammoh, Farhana } \\
\text { AlFaris, Eiad }\end{array}$ & $\begin{array}{l}\text { Stress coping strategies among medical students and trainees in Saudi Arabia: } \\
\text { a qualitative study }\end{array}$ \\
\hline N. J. e. a. Entwistle & $\begin{array}{l}\text { Student failure: disintegrated patterns of study strategies and perceptions of } \\
\text { the learning environment }\end{array}$ \\
\hline $\begin{array}{l}\text { N. L. Hung Van, Wongsa } \\
\text { Saengsuwan, Jiamjit } \\
\text { Thinkhamrop, Bandit Wright, } \\
\text { Pamela }\end{array}$ & $\begin{array}{l}\text { The relationships between the use of self-regulated learning strategies and } \\
\text { depression among medical students: An accelerated prospective cohort study }\end{array}$ \\
\hline N. L. O. Howells, Holly K. & $\begin{array}{l}\text { Diary study of sexual risk taking, alcohol use, and strategies for reducing } \\
\text { negative affect in female college students }\end{array}$ \\
\hline N. L. Xu, Yingyi & $\begin{array}{l}\text { Coping strategy mediates the relationship between body image evaluation and } \\
\text { mental health: A study with Chinese college students with disabilities }\end{array}$ \\
\hline $\begin{array}{l}\text { N. M. Ballenberger, Dirk } \\
\text { Zalpour, Christoff }\end{array}$ & $\begin{array}{l}\text { Musculoskeletal health complaints and corresponding risk factors among } \\
\text { music students study process, analysis strategies, and interim results from a } \\
\text { prospective cohort study }\end{array}$ \\
\hline N. M. M. Ghoneim & $\begin{array}{l}\text { The listening comprehension strategies used by college students to cope with } \\
\text { the aural problems in EFL classes: an analytical study }\end{array}$ \\
\hline N. M. M. Rao, B. E. Sachs, J. & $\begin{array}{l}\text { Motivational beliefs, study strategies, and mathematics attainment in high- } \\
\text { and low-achieving Chinese secondary school students }\end{array}$ \\
\hline $\begin{array}{l}\text { N. T. Imran, Khaula Fatima } \\
\text { Pervez, Muhammad Ijaz Jawaid, } \\
\text { Masood Haider, Imran Ijaz }\end{array}$ & $\begin{array}{l}\text { Medical students' stress, psychological morbidity, and coping strategies: a } \\
\text { cross-sectional study from Pakistan }\end{array}$ \\
\hline N. V. C. Volkova, V. A. & $\begin{array}{l}\text { Career aspirations of undergraduates studying at some strategic occupational } \\
\text { programs }\end{array}$ \\
\hline $\begin{array}{l}\text { N. V. Sanaie, Parvaneh Sedighi, } \\
\text { Ladan Sadeghi, Bita }\end{array}$ & $\begin{array}{l}\text { Comparing the effect of lecture and jigsaw teaching strategies on the nursing } \\
\text { students' self-regulated learning and academic motivation: a } \\
\text { quasi-experimental study }\end{array}$ \\
\hline $\begin{array}{l}\text { P. A. M. Alexander, P. Guan, } \\
\text { Joseph }\end{array}$ & The learning and study strategies of highly able female students in Singapore \\
\hline $\begin{array}{l}\text { P. A. M. Alexander, P. Karen } \\
\text { Woods, Bradford S. Duhon, } \\
\text { Karen E. Parker, Dawn }\end{array}$ & $\begin{array}{l}\text { College instruction and concomitant changes in students' knowledge, interest, } \\
\text { and strategy use: a study of domain learning }\end{array}$ \\
\hline $\begin{array}{l}\text { P. A. S. O. Moreira, Joao Tiago } \\
\text { Dias, Paulo Vaz, Filipa Machado } \\
\text { Torres-Oliveira, Isabel }\end{array}$ & $\begin{array}{l}\text { The students' perceptions of School Success Promoting Strategies Inventory } \\
\text { (SPSI): development and validity evidence based studies }\end{array}$ \\
\hline $\begin{array}{l}\text { P. A. Solano, Andrea Caprino, } \\
\text { Matilde Conigliaro, Claudia } \\
\text { Giacomini, Gabriele Serafini, } \\
\text { Gianluca Amore, Mario }\end{array}$ & $\begin{array}{l}\text { The personal experience of severe suicidal behaviour leads to negative } \\
\text { attitudes towards self- and other's suicidal thoughts and behaviours: A study } \\
\text { of temperaments, coping strategies, and attitudes towards suicide among } \\
\text { medical students }\end{array}$ \\
\hline P. Adhikary & English language learning strategies adopted by bachelor level students (A \\
\hline
\end{tabular}




\begin{tabular}{|c|c|}
\hline & case study of Nepal) \\
\hline $\begin{array}{l}\text { P. C. N. Rosario, Jose Valle, } \\
\text { Antonio Gonzalez-Pienda, Julio } \\
\text { Lourenco, Abilio }\end{array}$ & $\begin{array}{l}\text { Grade level, study time, and grade retention and their effects on motivation, } \\
\text { self-regulated learning strategies, and mathematics achievement: a structural } \\
\text { equation model }\end{array}$ \\
\hline $\begin{array}{l}\text { P. M. D. Schulz, Carmel L. } \\
\text { Burdett-Jones, Denise Gamble, } \\
\text { Natalie S. Kosiak, Machellee M. } \\
\text { Neal, Joclyn M. Baker, Gail E. }\end{array}$ & $\begin{array}{l}\text { Evaluation of strategies designed to enhance student engagement and success } \\
\text { of indigenous midwifery students in an away-from-base bachelor of } \\
\text { midwifery program in australia: A qualitative research study }\end{array}$ \\
\hline $\begin{array}{l}\text { P. N. Forbus, John J. Mehta, } \\
\text { Sanjay S. }\end{array}$ & $\begin{array}{l}\text { A study of non-traditional and traditional students in terms of their time } \\
\text { management behaviours, stress factors, and coping strategies }\end{array}$ \\
\hline $\begin{array}{l}\text { P. Syawal, Nasrullah, A. S. Ali } \\
\text { Wira, Rahman }\end{array}$ & $\begin{array}{l}\text { Good EFL learner's strategy In enhancing english mastery: a case study at } \\
\text { indonesian college students }\end{array}$ \\
\hline $\begin{array}{l}\text { P. W. Whannell, Robert Allen, } \\
\text { Bill }\end{array}$ & $\begin{array}{l}\text { Investigating the influence of teacher strategies on academic self-efficacy and } \\
\text { study behaviour of students in a tertiary bridging program }\end{array}$ \\
\hline $\begin{array}{l}\text { Q. S. Bukhsh, Abid Nisa, } \\
\text { Muzammil }\end{array}$ & $\begin{array}{l}\text { A study of learning stress and stress management strategies of the students of } \\
\text { postgraduate level: a case study of islamia university of Bahawalpur, Pakistan }\end{array}$ \\
\hline Q. Wang & $\begin{array}{l}\text { Lexical inferencing strategies for dealing with unknown words in reading: a } \\
\text { contrastive study between filipino graduate students and chinese graduate } \\
\text { students }\end{array}$ \\
\hline $\begin{array}{l}\text { R. d. S. Ekuni, Bruno Miguel } \\
\text { Nogueira Agarwal, Pooja K. } \\
\text { Pompeia, Sabine }\end{array}$ & $\begin{array}{l}\text { A conceptual replication of survey research on study strategies in a diverse, } \\
\text { non-WEIRD student population }\end{array}$ \\
\hline $\begin{array}{l}\text { R. D. Zazkis, Ed Dautermann, } \\
\text { Jennie }\end{array}$ & $\begin{array}{l}\text { Coordinating visual and analytic strategies: a study of students' understanding } \\
\text { of the group } \mathrm{D}_{4}\end{array}$ \\
\hline R. H. DeMarco, L. Lynch, M. & $\begin{array}{l}\text { Nursing students' experiences with and strategic approaches to case-based } \\
\text { instruction: a replication and comparison study between two disciplines }\end{array}$ \\
\hline R. I. A.-M. Rabadi, Batoul & $\begin{array}{l}\text { An empirical study on vocabulary learning strategies by jordanian FFL } \\
\text { university students }\end{array}$ \\
\hline $\begin{array}{l}\text { R. J. Andreassen, Magne S. } \\
\text { Braten, Ivar }\end{array}$ & $\begin{array}{l}\text { Investigating self-regulated study strategies among postsecondary students } \\
\text { with and without dyslexia: a diary method study }\end{array}$ \\
\hline $\begin{array}{l}\text { R. J. Andreassen, Magne S. } \\
\text { Bråten, Ivar }\end{array}$ & $\begin{array}{l}\text { Investigating self-regulated study strategies among postsecondary students } \\
\text { with and without dyslexia: a diary method study }\end{array}$ \\
\hline $\begin{array}{l}\text { R. K. Sahragard, Yaser } \\
\text { Abbasian, Reza }\end{array}$ & $\begin{array}{l}\text { Field of study, learning styles, and language learning strategies of university } \\
\text { students: are there any relations? }\end{array}$ \\
\hline $\begin{array}{l}\text { R. L. A. Ugla, Mohamad Jafre } \\
\text { Zainol }\end{array}$ & A study of apology strategies used by Iraqi EFL university students \\
\hline $\begin{array}{l}\text { R. L. Petersen, Ellen Guarino, } \\
\text { A. J. }\end{array}$ & $\begin{array}{l}\text { The relationship between college students' executive functioning and study } \\
\text { strategies }\end{array}$ \\
\hline
\end{tabular}




\begin{tabular}{|c|c|}
\hline $\begin{array}{l}\text { R. L. Steele, W. Caperchione, C. } \\
\text { Anastasi, J. }\end{array}$ & $\begin{array}{l}\text { An exploratory study of the concerns of mature access to nursing students and } \\
\text { the coping strategies used to manage these adverse experiences }\end{array}$ \\
\hline $\begin{array}{l}\text { R. M. Herrero, Adriana Cormo, } \\
\text { Giulia Etchemendy, Ernestina } \\
\text { Banos, Rosa Garcia-Palacios, } \\
\text { Azucena Ebert, David D. } \\
\text { Franke, Marvin Berger, Thomas } \\
\text { Schaub, Michael P. Goerlich, } \\
\text { Dennis Jacobi, Corinna Botella, } \\
\text { Cristina }\end{array}$ & $\begin{array}{l}\text { An internet based intervention for improving resilience and coping strategies } \\
\text { in university students: study protocol for a randomized controlled trial }\end{array}$ \\
\hline $\begin{array}{l}\text { R. T. H. Roessler, Mary L. } \\
\text { Rumrill, Phillip D. }\end{array}$ & $\begin{array}{l}\text { Strategies for improving career services for postsecondary students with } \\
\text { disabilities: results of a focus group study of key stakeholders }\end{array}$ \\
\hline S. B. H. Nolen, Thomas M. & $\begin{array}{l}\text { Personal and environmental influences on students' beliefs about effective } \\
\text { study strategies }\end{array}$ \\
\hline S. B. H. Nolen, Thomas M. & $\begin{array}{l}\text { A construct validation of measures of students' study strategy beliefs and } \\
\text { perceptions of teacher goals }\end{array}$ \\
\hline $\begin{array}{l}\text { S. C. J. Ender, F. A. Novels, A. } \\
\text { N. Moss, R. A. Wray, H. }\end{array}$ & $\begin{array}{l}\text { College work study as an affirmative-action strategy promoting student } \\
\text { involvement }\end{array}$ \\
\hline $\begin{array}{l}\text { S. F. E. S. Rovers, Renee E. van } \\
\text { Merrienboer, Jeroen J. G. } \\
\text { Savelberg, Hans H. C. M. de } \\
\text { Bruin, Anique B. H. }\end{array}$ & $\begin{array}{l}\text { How and why do students use learning strategies? A mixed methods study on } \\
\text { learning strategies and desirable difficulties with effective strategy users }\end{array}$ \\
\hline S. G. Nielsen & $\begin{array}{l}\text { Strategies and self-efficacy beliefs in instrumental and vocal individual } \\
\text { practice: a study of students in higher music education }\end{array}$ \\
\hline S. J. Stoynoff & $\begin{array}{l}\text { English language proficiency and study strategies as determinants of academic } \\
\text { success for international students in U.S. universities }\end{array}$ \\
\hline $\begin{array}{l}\text { S. L. R. Simon-Dack, P. Dennis } \\
\text { Marcum, Geoff D. }\end{array}$ & $\begin{array}{l}\text { Study habits, motives, and strategies of college students with symptoms of } \\
\text { ADHD }\end{array}$ \\
\hline S. M. Bryant & $\begin{array}{l}\text { The effects of visualization and verbalization as study strategies on middle } \\
\text { school students' retention of defined concepts learned from expository text }\end{array}$ \\
\hline S. M. F. Bacon, Michael D. & $\begin{array}{l}\text { A study of the attitudes, motives, and strategies of university foreign language } \\
\text { students and their disposition to authentic oral and written input }\end{array}$ \\
\hline $\begin{array}{l}\text { S. N. S. Mojarad, Somayeh } \\
\text { AhmadiGatab, Teymor }\end{array}$ & $\begin{array}{l}\text { Studying the effects of teaching cognitive and metacognitive strategies on } \\
\text { self-efficacy and goal-selecting of orphan girl students }\end{array}$ \\
\hline S. S. Hung-Bin, William E. & $\begin{array}{l}\text { An exploratory study of help-seeking attitudes and coping strategies among } \\
\text { college students by race and gender }\end{array}$ \\
\hline S. S. Sutiyatno & $\begin{array}{l}\text { A survey study: the correlation between metacognitive strategies and reading } \\
\text { achievement }\end{array}$ \\
\hline $\begin{array}{l}\text { T. L. Uwatoko, Yan Sakata, } \\
\text { Masatsugu Kobayashi, Daisuke }\end{array}$ & $\begin{array}{l}\text { Healthy campus trial: a multiphase optimization strategy (MOST) fully } \\
\text { factorial trial to optimize the smartphone cognitive behavioral therapy (CBT) }\end{array}$ \\
\hline
\end{tabular}




\begin{tabular}{|c|c|}
\hline $\begin{array}{l}\text { Sakagami, Yu Takemoto, } \\
\text { Kazumi Collins, Linda M. } \\
\text { Watkins, Ed Hollons, Steven D. } \\
\text { Wason, James Noma, Hisashi } \\
\text { Horikoshi, Masaru Kawamura, } \\
\text { Takashi Iwami, Taku Furukawa, } \\
\text { Toshi A. }\end{array}$ & $\begin{array}{l}\text { app for mental health promotion among university students: study protocol for } \\
\text { a randomized controlled trial }\end{array}$ \\
\hline $\begin{array}{l}\text { T. M. P. Chevalier, Rauno } \\
\text { Ritchie, Krista C. Deacon, S. } \\
\text { Hélène }\end{array}$ & $\begin{array}{l}\text { The role of metacognitive reading strategies, metacognitive study and learning } \\
\text { strategies, and behavioral study and learning strategies in predicting academic } \\
\text { success in students with and without a history of reading difficulties }\end{array}$ \\
\hline T. Mushoriwa & $\begin{array}{l}\text { The study strategy: performance function among students in three teachers' } \\
\text { colleges in Masvingo and Harare, Zimbabwe }\end{array}$ \\
\hline T. S. Whetstone & $\begin{array}{l}\text { Getting stripes: educational achievement and study strategies used by sergeant } \\
\text { promotional candidates }\end{array}$ \\
\hline U. V. M. Chinwe, Ikezu Uju Joy & $\begin{array}{l}\text { Causes, effects and strategies for eradicating cultism among students in } \\
\text { tertiary institutions in nigeria: a case study of nnamdi azikiwe university awka } \\
\text { anambra state, nigeria }\end{array}$ \\
\hline $\begin{array}{l}\text { V. G. S. Spencer, T. E. } \\
\text { Mastropieri, M. A. }\end{array}$ & $\begin{array}{l}\text { Content area learning in middle school social studies classrooms and students } \\
\text { with emotional or behavioral disorders: A comparison of strategies }\end{array}$ \\
\hline V. M. Adams & $\begin{array}{l}\text { Comparing paper-based and electronic outlining as a study strategy for } \\
\text { mainstreamed students with learning disabilities }\end{array}$ \\
\hline $\begin{array}{l}\text { V. M. McInerney, Dennis M. } \\
\text { Marsh, Herbert W. }\end{array}$ & $\begin{array}{l}\text { Effects of metacognitive strategy training within a cooperative group learning } \\
\text { context on computer achievement and anxiety: An aptitude-treatment } \\
\text { interaction study }\end{array}$ \\
\hline $\begin{array}{l}\text { W. D. DeJong, Beth Schneider, } \\
\text { Shari Kessel }\end{array}$ & $\begin{array}{l}\text { Pregaming: An exploratory study of strategic drinking by college students in } \\
\text { Pennsylvania }\end{array}$ \\
\hline W. F. Geiser & $\begin{array}{l}\text { Effects of learning-style awareness and responsive study strategies on } \\
\text { achievement in, incidence of study of, and attitude toward mathematics of } \\
\text { suburban eighth-grade }\end{array}$ \\
\hline $\begin{array}{l}\text { W. V. D. B. Tops, An Noens, } \\
\text { Ilse Baeyens, Dieter }\end{array}$ & $\begin{array}{l}\text { A multi-method assessment of study strategies in higher education students } \\
\text { with an autism spectrum disorder }\end{array}$ \\
\hline $\begin{array}{l}\text { W.-P. Y. Chou, Cheng-Fang Liu, } \\
\text { Tai-Ling }\end{array}$ & $\begin{array}{l}\text { Predicting effects of psychological inflexibility/experiential avoidance and } \\
\text { stress coping strategies for internet addiction, significant depression, and } \\
\text { suicidality in college students: a prospective study }\end{array}$ \\
\hline X. D. Z. Xu, Q. L. Chen, X. Y. & $\begin{array}{l}\text { The experimental study of thinking strategy training about the effect on the } \\
\text { ability of students in senior high school solving chemical calculation problems }\end{array}$ \\
\hline X. Liu & $\begin{array}{l}\text { The relationship between the depth of vocabulary knowledge and chinese MA } \\
\text { students' use of vocabulary learning strategy and L } 2 \text { contact in a study-abroad } \\
\text { context }\end{array}$ \\
\hline X. M. Zhu, Jianqing & $\begin{array}{l}\text { A study on employability of contemporary chinese university students and } \\
\text { improvement strategies }\end{array}$ \\
\hline
\end{tabular}




\begin{tabular}{|c|c|}
\hline X. X. Chen, Gengsheng & $\begin{array}{l}\text { A survey study of chinese college engineering students' use of metacognitive } \\
\text { strategies in english writing }\end{array}$ \\
\hline X. Z. Chen, D. J. & $\begin{array}{l}\text { A study of the relationships among stressors in school work, coping strategies } \\
\text { and psychological health in secondary school students }\end{array}$ \\
\hline $\begin{array}{l}\text { Y. C. Alshahrani, Lynette } \\
\text { Rasmussen, Philippa }\end{array}$ & $\begin{array}{l}\text { Undergraduate nursing students' strategies for coping with their first clinical } \\
\text { placement: descriptive survey study }\end{array}$ \\
\hline Y. Cai & A study on compliment response strategies by chinese college students \\
\hline Y. W. Lee, Evelin & $\begin{array}{l}\text { Teachers' intended classroom management strategies for students with ADHD: } \\
\text { a cross-cultural study between South Korea and Germany }\end{array}$ \\
\hline Y. W. Lee, Evelin & $\begin{array}{l}\text { Teachers' accuracy in identifying ADHD status and their intended classroom } \\
\text { management strategies for students with and without ADHD: a vignette study } \\
\text { in South-Korea and Germany }\end{array}$ \\
\hline Y.-C. J. Hsieh & $\begin{array}{l}\text { The cross-cultural study on the effect of the use of student-generated } \\
\text { visualization as a study strategy for middle school science concept learning }\end{array}$ \\
\hline $\begin{array}{l}\text { Y.-M. T. Lim, Cai-Lian Lee, } \\
\text { Teck-Heang }\end{array}$ & $\begin{array}{l}\text { Perceived stress, coping strategy and general health: a study on accounting } \\
\text { students in malaysia }\end{array}$ \\
\hline Z. Gan & $\begin{array}{l}\text { Asian learners re-examined: an empirical study of language learning attitudes, } \\
\text { strategies and motivation among mainland chinese and hong kong students }\end{array}$ \\
\hline Z. L. Cao, Yuewu & $\begin{array}{l}\text { A study on metacognitive strategy use in listening comprehension by } \\
\text { vocational college students }\end{array}$ \\
\hline Z. L. Rao, Fulan & $\begin{array}{l}\text { Effect of academic major on students' use of language learning strategies: a } \\
\text { diary study in a chinese context }\end{array}$ \\
\hline Z. Zhou & $\begin{array}{l}\text { The empirical study into the relation of the meta-cognitive strategy use and } \\
\text { english achievement of college students }\end{array}$ \\
\hline
\end{tabular}

\section{Excluded articles from database full-text screen}

\begin{tabular}{|l|l|}
\hline Author & $\underline{\text { Title }}$ \\
\hline A. A. Al-Emadi & The relationships among achievement, goal orientation, and study strategies \\
\hline $\begin{array}{l}\text { A. F. L. Hoffmann, Ruben } \\
\text { Fernandez Liporace, Maria } \\
\text { Mercedes }\end{array}$ & $\begin{array}{l}\text { Psychometric analysis of the Learning and Study Strategies Inventory in } \\
\text { college students }\end{array}$ \\
\hline A. J. M. Elliot, H. A. Gable, S. & $\begin{array}{l}\text { Achievement goals, study strategies, and exam performance: A mediational } \\
\text { analysis }\end{array}$ \\
\hline $\begin{array}{l}\text { A. L. Freiberg Hoffmann, } \\
\text { Ruben Fernandez Liporace, } \\
\text { Maria Mercedes }\end{array}$ & $\begin{array}{l}\text { Psychometric Analysis of the Learning and Study Strategies Inventory in } \\
\text { College Students }\end{array}$ \\
\hline $\begin{array}{l}\text { A. M. Belshaw, Adam Phillips, } \\
\text { Hannah Kay Rodrigues, Hannah }\end{array}$ & $\begin{array}{l}\text { Comment on: creating assessments as an active learning strategy: what are } \\
\text { students' perceptions? A mixed methods study }\end{array}$ \\
\hline
\end{tabular}




\begin{tabular}{|c|c|}
\hline \multicolumn{2}{|l|}{ Russell, Andrew } \\
\hline A. M. Meshbane, John D. & $\begin{array}{l}\text { Effectiveness of a mnemonic study strategy for retention of geographic names } \\
\text { and locations by college students }\end{array}$ \\
\hline A. M. Persky & A four year longitudinal study of student learning strategies \\
\hline A. R. Lorenzo & $\begin{array}{l}\text { Comparative study on the performance of bachelor of secondary education } \\
\text { (BSE) students in educational technology using blended learning strategy and } \\
\text { traditional face-to-face instruction }\end{array}$ \\
\hline B. R. Dawson & $\begin{array}{l}\text { Textbook reading strategies used by "study strategies for college success" } \\
\text { students in content courses during the following semesters }\end{array}$ \\
\hline $\begin{array}{l}\text { B. W. D. Bergey, S. Hélène } \\
\text { Parrila, Rauno K. }\end{array}$ & $\begin{array}{l}\text { Metacognitive reading and study strategies and academic achievement of } \\
\text { university students with and without a history of reading difficulties }\end{array}$ \\
\hline $\begin{array}{l}\text { B. W. P. Bergey, Rauno K. } \\
\text { Laroche, Annie Deacon, S. }\end{array}$ & $\begin{array}{l}\text { Effects of peer-led training on academic self-efficacy, study strategies, and } \\
\text { academic performance for first-year university students with and without } \\
\text { reading difficulties }\end{array}$ \\
\hline C. A. Baldwin & $\begin{array}{l}\text { Achievement goals and exam performance: An exploration of the role of study } \\
\text { strategies and anticipatory test anxiety }\end{array}$ \\
\hline $\begin{array}{l}\text { C. A. M. Christensen, D. R. } \\
\text { Isaacs, P. J. }\end{array}$ & $\begin{array}{l}\text { Cognitive strategies and study habits - An analysis of the measurement of } \\
\text { tertiary students learning }\end{array}$ \\
\hline C. D. Zepeda & $\begin{array}{l}\text { Self-regulated learning in a college course: Examining student metacognitive } \\
\text { study strategies, grit, self-efficacy, and performance }\end{array}$ \\
\hline C. Gutierrez-Braojos & $\begin{array}{l}\text { Future time orientation and learning conceptions: effects on metacognitive } \\
\text { strategies, self-efficacy beliefs, study effort and academic achievement }\end{array}$ \\
\hline $\begin{array}{l}\text { C. J. Z. Fong, Linda Reichwein } \\
\text { Ozel, Zeynep Ebrar Yetkiner } \\
\text { Phelps, Julie M. }\end{array}$ & $\begin{array}{l}\text { Between and within ethnic differences in strategic learning: a study of } \\
\text { developmental mathematics students }\end{array}$ \\
\hline C. Li & $\begin{array}{l}\text { Study on the relationship among strategies in language learning, achievement } \\
\text { motivation and academic scores of students in normal university }\end{array}$ \\
\hline C. Magno & Assessing students' study strategies and achievement goals \\
\hline C. Metzgen & $\begin{array}{l}\text { College-student learning and study strategies: A cross-cultural study between } \\
\text { Switzerland and the United States }\end{array}$ \\
\hline D. F. Sacks & $\begin{array}{l}\text { The effects of the direct instruction of study strategies on first year college } \\
\text { students' strategy use }\end{array}$ \\
\hline D. J. Eberling & $\begin{array}{l}\text { A comparison of the effectiveness of study strategies instruction with } \\
\text { community college students }\end{array}$ \\
\hline $\begin{array}{l}\text { D. J. O. Dickinson, D. Q. Dunn, } \\
\text { J. S. }\end{array}$ & Distributed study, cognitive study strategies and aptitude on student learning \\
\hline D. Jairam & Helping students soar to success on their computer: A mixed methods \\
\hline
\end{tabular}




\begin{tabular}{|c|c|}
\hline & $\begin{array}{l}\text { approach to investigate and test an integrated study strategy system for online } \\
\text { prose }\end{array}$ \\
\hline D. Watkins & Academic achievement and the congruence of study motivation and strategy \\
\hline $\begin{array}{l}\text { F. d. M. Van Overwalle, } \\
\text { Machteld }\end{array}$ & $\begin{array}{l}\text { The effects of attribution-based intervention and study strategy training on } \\
\text { academic achievement in college freshmen }\end{array}$ \\
\hline $\begin{array}{l}\text { F. J. P. G.-P. Estrada, Francisco } \\
\text { Javier Conde-Vélez, Sara }\end{array}$ & $\begin{array}{l}\text { Learning styles in university students: Types of strategies, materials, supports, } \\
\text { evaluation and performance. case study }\end{array}$ \\
\hline F. Phillips & $\begin{array}{l}\text { A research note on accounting students' epistemological beliefs, study } \\
\text { strategies, and unstructured problem-solving performance }\end{array}$ \\
\hline G. A. Hale & Students predictions of prose forgetting and the effects of study strategies \\
\hline G. Erdamar & $\begin{array}{l}\text { An investigation of student teachers' study strategies with respect to certain } \\
\text { variables }\end{array}$ \\
\hline G. Jean-Louis & $\begin{array}{l}\text { Skill, will, and self-regulation: Assessing the learning and study strategies of } \\
\text { university summer bridge program students }\end{array}$ \\
\hline H. D. Mason & $\begin{array}{l}\text { Learning and study strategies among first-year students at a south african } \\
\text { university: A mixed methods study }\end{array}$ \\
\hline $\begin{array}{l}\text { H. I. B. Stromso, I. } \\
\text { Samuelstuen, M. S. }\end{array}$ & $\begin{array}{l}\text { Students' strategic use of multiple sources during expository text reading: A } \\
\text { longitudinal think-aloud study }\end{array}$ \\
\hline $\begin{array}{l}\text { H. K. Jabbari, M. K. Heydari, } \\
\text { M. }\end{array}$ & $\begin{array}{l}\text { The comparatively study of student in the eye of locus of control, motivational } \\
\text { beliefs,and self regulated learning strategies }\end{array}$ \\
\hline $\begin{array}{l}\text { H. M. A.-M. Al Kadri, } \\
\text { Mohamed S. Elzubair, Margaret } \\
\text { Magzoub, Mohi Eldien } \\
\text { AlMutairi, Abdulrahman } \\
\text { Roberts, Christopher van der } \\
\text { Vleuten, Cees }\end{array}$ & $\begin{array}{l}\text { Exploring factors affecting undergraduate medical students' study strategies in } \\
\text { the clinical years: A qualitative study }\end{array}$ \\
\hline H. N. Alkhateeb, Ramzi & $\begin{array}{l}\text { Assessment of learning and study strategies of university students in Qatar } \\
\text { using an arabic translation of the Learning and Study Strategies Inventory }\end{array}$ \\
\hline H. P. Phan & $\begin{array}{l}\text { Amalgamation of future time orientation, epistemological beliefs, achievement } \\
\text { goals and study strategies: Empirical evidence established }\end{array}$ \\
\hline I. O. Braten, B. S. & The learning and study strategies of Norwegian first-year college students \\
\hline J. A. S. Lawrence, Ram P. & $\begin{array}{l}\text { A study of teaching and testing strategies for a required statistics course for } \\
\text { undergraduate business students }\end{array}$ \\
\hline J. B. Biggs & Motivation to learn and students study strategies \\
\hline $\begin{array}{l}\text { J. B. L. Kurtz, Michael A. } \\
\text { Holman, Elizabeth E. Grob, } \\
\text { Karri L. Monrad, Seetha U. }\end{array}$ & $\begin{array}{l}\text { Creating assessments as an active learning strategy: what are students' } \\
\text { perceptions? A mixed methods study }\end{array}$ \\
\hline
\end{tabular}




\begin{tabular}{|c|c|}
\hline J. Biggs & $\begin{array}{l}\text { A comparison of student motivation and study strategies in CAE and } \\
\text { university populations }\end{array}$ \\
\hline J. C. Moore & $\begin{array}{l}\text { Cognitive, learning and study strategy predictors of student-athlete academic } \\
\text { success and academic progress rates }\end{array}$ \\
\hline $\begin{array}{l}\text { J. D. B. Karpicke, Andrew C. } \\
\text { Roediger, Henry L., III }\end{array}$ & $\begin{array}{l}\text { Metacognitive strategies in student learning: Do students practise retrieval } \\
\text { when they study on their own? }\end{array}$ \\
\hline J. M. Oliver & $\begin{array}{l}\text { The relationship between learning/study strategies and gains in algebra i } \\
\text { competency among developmental mathematics students }\end{array}$ \\
\hline J. N. Laakkonen, Anne & $\begin{array}{l}\text { Relationships between learning strategies, stress, and study success among } \\
\text { first-year veterinary students during an educational transition phase }\end{array}$ \\
\hline J. O. Mäkinen, Erkki & $\begin{array}{l}\text { University students' situational reaction tendencies: reflections on general } \\
\text { study orientations, learning strategies, and study success }\end{array}$ \\
\hline $\begin{array}{l}\text { J. R. B. King, Shirley Lipsky, } \\
\text { Sally }\end{array}$ & Students' self-questioning and summarizing as reading study strategies \\
\hline J. S. Martinezguerrero, J. J. & $\begin{array}{l}\text { Learning strategies - predictive analysis of study habits on college students } \\
\text { academic performance }\end{array}$ \\
\hline J. S. Sriram & $\begin{array}{l}\text { Enabling students to learn: design, implementation and assessment of a } \\
\text { supplemental study strategies course for an introductory undergraduate } \\
\text { biology course }\end{array}$ \\
\hline $\begin{array}{l}\text { J. V. Ferla, Martin Schuyten, } \\
\text { Gilberte }\end{array}$ & Relationships between student cognitions and their effects on study strategies \\
\hline K. R. Francom & $\begin{array}{l}\text { Achievement motivation and study strategies of graduate students: testing } \\
\text { boundary conditions of theoretical constructs }\end{array}$ \\
\hline $\begin{array}{l}\text { K. T. R. Rugsaken, Jacqueline } \\
\text { A. Jones, James A. }\end{array}$ & $\begin{array}{l}\text { Using the learning and study strategies inventory scores as additional } \\
\text { predictors of student academic performance }\end{array}$ \\
\hline $\begin{array}{l}\text { L. A. B. Flowers, Brian K. } \\
\text { Moore, James L., III }\end{array}$ & $\begin{array}{l}\text { Concurrent validity of the Learning and Study Strategies Inventory (LASSI): } \\
\text { A study of African American pre college students }\end{array}$ \\
\hline L. B. Hodo & $\begin{array}{l}\text { The effects of study skills instruction on achievement and usage of selected } \\
\text { study strategies in Algebra II classes }\end{array}$ \\
\hline L. M. Chen, Jianqing & $\begin{array}{l}\text { Empirical Study on Incentive Education Strategies for College Students in } \\
\text { Social Transition Period }\end{array}$ \\
\hline $\begin{array}{l}\text { L. M. S. Ramjan, Lyn } \\
\text { Salamonson, Yenna Morris, } \\
\text { Maureen M. Armstrong, Lyn } \\
\text { Sanchez, Paula Flannery, Liz }\end{array}$ & $\begin{array}{l}\text { Identifying strategies to assist final semester nursing students to develop } \\
\text { numeracy skills: A mixed methods study }\end{array}$ \\
\hline L. P. Franciosi & $\begin{array}{l}\text { Problem-solving appraisal, self-reported study strategies, and academic } \\
\text { performance of first-year college students }\end{array}$ \\
\hline M. A. Dahlgren & Portraits of PBL: Course objectives and students' study strategies in computer \\
\hline
\end{tabular}




\begin{tabular}{|c|c|}
\hline & engineering, psychology and physiotherapy \\
\hline M. E. Ross & $\begin{array}{l}\text { The effects of student expectations about the cognitive complexity of test } \\
\text { items on study strategies and on memorization and cognitively complex test } \\
\text { item performance }\end{array}$ \\
\hline $\begin{array}{l}\text { M. K. McAndrew, Rajit S. } \\
\text { Pierre, Gaelle C. }\end{array}$ & Do dental students use optimal study strategies? \\
\hline M. L. N. Simpson, Sherrie L. & $\begin{array}{l}\text { Textbook annotation: an effective and efficient study strategy for college } \\
\text { students }\end{array}$ \\
\hline M. L. Smith & $\begin{array}{l}\text { A quantitative analysis of critical thinking abilities, learning and study } \\
\text { strategies, and academic achievement in associate degree nursing students }\end{array}$ \\
\hline $\begin{array}{l}\text { M. M. M. Cavamura Endo, } \\
\text { Fabiano Koich Kienen, Nadia }\end{array}$ & The learning and study strategies of Norwegian first-year college students \\
\hline M. Nebres & $\begin{array}{l}\text { Training in summarizing notes: Effects of teaching students a self-regulation } \\
\text { study strategy in science learning }\end{array}$ \\
\hline $\begin{array}{l}\text { M. P. V.-G. Deming, Maria } \\
\text { Idleman, Lynda S. }\end{array}$ & $\begin{array}{l}\text { The reliability and validity of Learning and Study Strategies Inventory } \\
\text { (LASSI) with college developmental students }\end{array}$ \\
\hline $\begin{array}{l}\text { M. R.-G. Ruiz-López, Marta } \\
\text { Villanueva, } \\
\text { Purificación-González } \\
\text { Márquez-Cava, Montserrat } \\
\text { García-Mateos, Mónica } \\
\text { Ruiz-Ruiz, Beatriz } \\
\text { Herrera-Sánchez, Esteban }\end{array}$ & $\begin{array}{l}\text { The use of reflective journaling as a learning strategy during the clinical } \\
\text { rotations of students from the faculty of health sciences: An action-research } \\
\text { study }\end{array}$ \\
\hline $\begin{array}{l}\text { M. V. S. Pinxten, Carolien } \\
\text { Peeters, Christine De Laet, } \\
\text { Tinne Langie, Greet }\end{array}$ & $\begin{array}{l}\text { At-risk at the gate: Prediction of study success of first-year science and } \\
\text { engineering students in an open-admission university in Flanders-any } \\
\text { incremental validity of study strategies? }\end{array}$ \\
\hline O. J. Ehindero & $\begin{array}{l}\text { A discriminant function analysis of study strategies, logical reasoning ability } \\
\text { and achievement across major teacher undergraduate curricula }\end{array}$ \\
\hline $\begin{array}{l}\text { O. O. Z. Adesope, Mingming } \\
\text { Nesbit, John C. }\end{array}$ & $\begin{array}{l}\text { Achievement goal orientations and self-reported study strategies as predictors } \\
\text { of online studying activities }\end{array}$ \\
\hline S. B. H. Nolen, T. M. & $\begin{array}{l}\text { Personal and environmental influences on students beliefs about effective } \\
\text { study strategies }\end{array}$ \\
\hline $\begin{array}{l}\text { S. H. M. Moon, Sun Jung Yoon, } \\
\text { Hyun Bae Park, Jun-Bean Kim, } \\
\text { Ju Whi Park, Wan Beom }\end{array}$ & $\begin{array}{l}\text { Deliberate practice as an effective remediation strategy for underperforming } \\
\text { medical students focused on clinical skills: a prospective longitudinal study }\end{array}$ \\
\hline S. K. Grimes & $\begin{array}{l}\text { Targeting academic programs to student diversity utilizing learning styles and } \\
\text { learning-study strategies }\end{array}$ \\
\hline T. G. Jakubowski & $\begin{array}{l}\text { Social-cognitive factors associated with the academic self-regulation of } \\
\text { undergraduate college students in a learning and study strategies course }\end{array}$ \\
\hline
\end{tabular}




\begin{tabular}{|l|l|}
\hline $\begin{array}{l}\text { U. W. Isik, Janneke Croiset, } \\
\text { Gerda Kusurkar, Rashmi A. }\end{array}$ & $\begin{array}{l}\text { The role of study strategy in motivation and academic performance of ethnic } \\
\text { minority and majority students: A structural equation model }\end{array}$ \\
\hline $\begin{array}{l}\text { U. W. Schiefele, K. P. Winteler, } \\
\text { A. }\end{array}$ & $\begin{array}{l}\text { Amount of learning and elaboration strategies as mediators of the relation } \\
\text { between study interest and achievement }\end{array}$ \\
\hline $\begin{array}{l}\text { Y. E. Salamonson, Bronwyn } \\
\text { Koch, Jane Wilson, Ian } \\
\text { Davidson, Patricia M. }\end{array}$ & $\begin{array}{l}\text { Learning strategies of first year nursing and medical students: A comparative } \\
\text { study }\end{array}$ \\
\hline
\end{tabular}

\section{Excluded articles from manual search abstract screen}

\begin{tabular}{|c|c|}
\hline$\underline{\text { Author }}$ & $\underline{\text { Title }}$ \\
\hline Pan JY, Wong DF & $\begin{array}{l}\text { Acculturative stressors and acculturative strategies as predictors of negative } \\
\text { affect among Chinese international students in Australia and Hong Kong: a } \\
\text { cross-cultural comparative study }\end{array}$ \\
\hline Jacob B, Peasah SK & $\begin{array}{l}\text { An Elective Course for Student Pharmacists on Pharmaceutical Industry } \\
\text { Practice }\end{array}$ \\
\hline $\mathrm{AACN}$ & $\begin{array}{l}\text { AACN practice guidelines for neuropsychological assessment and } \\
\text { consultation. Clinical Neuropsychology }\end{array}$ \\
\hline Advokat C, Lane SM, Luo C & $\begin{array}{l}\text { College students with and without ADHD: Comparison of self-report of } \\
\text { medication usage, study habits, and academic achievement }\end{array}$ \\
\hline $\begin{array}{l}\text { Afflerbach, P., Pearson, P. D., \& } \\
\text { Paris, S. G. }\end{array}$ & Clarifying differences between reading skills and reading strategies \\
\hline $\begin{array}{l}\text { Agar, D. L. and Knopfmacher, } \\
\text { N. }\end{array}$ & The Learning and Study Strategies Inventory: A South African application \\
\hline $\begin{array}{l}\text { Allen, G. J., Lerner, W. M., } \\
\text { Hinrichsen, J. J. }\end{array}$ & $\begin{array}{l}\text { Study behaviors and their relationships to test anxiety and academic } \\
\text { performance }\end{array}$ \\
\hline $\begin{array}{l}\text { Andrews, J., Violato, C., Rabb, } \\
\text { K., \& Hollingsworth, M. }\end{array}$ & $\begin{array}{l}\text { A validity study of Biggs' three-factor model of learning approaches: A } \\
\text { confirmatory factor analysis employing a Canadian sample }\end{array}$ \\
\hline Arbuckle, J. L. & Amos user guide \\
\hline Bandura A. & Social Foundations of Thought and Action: A Social Cognitive Theory \\
\hline $\begin{array}{l}\text { Roghayeh Gandomkar, Kamran } \\
\text { Yazdani, Ladan Fata, Ramin } \\
\text { Mehrdad, Azim Mirzazadeh, } \\
\text { Mohammad Jalili, John Sandars }\end{array}$ & $\begin{array}{l}\text { Using multiple self-regulated learning measures to understand medical } \\
\text { students' biomedical science learning }\end{array}$ \\
\hline A. J., \& McGregor, H. A. & A $2 \times 2$ achievement goal framework \\
\hline ACPE & $\begin{array}{l}\text { Accreditation standards and guidelines for the professional program in } \\
\text { pharmacy leading to the doctor of pharmacy degree }\end{array}$ \\
\hline
\end{tabular}




\begin{tabular}{|c|c|}
\hline $\begin{array}{l}\text { Agboola SO, Bates DW, Kvedar } \\
\text { JC. }\end{array}$ & Digital health and patient safety \\
\hline $\begin{array}{l}\text { Albard, K. E., \& Lipschultz, R. } \\
\text { E. }\end{array}$ & $\begin{array}{l}\text { Self-regulated learning in high-achieving students: relations to advanced } \\
\text { reasoning, achievement goals, and gender }\end{array}$ \\
\hline Alexander, P. A. & The development of expertise: the journey from acclimation to proficiency \\
\hline Alexander, P. A. & Evolution of a learning theory: A case study \\
\hline Alkhasawneh E. & $\begin{array}{l}\text { Using VARK to assess changes in learning preferences of nursing students at } \\
\text { a public university in Jordan: Implications for teaching }\end{array}$ \\
\hline $\begin{array}{l}\text { Alkhasawneh IM, Mrayyan MT, } \\
\text { Docherty C, Alashram S, Yousef } \\
\text { HY. }\end{array}$ & $\begin{array}{l}\text { Problem-based learning (PBL): Assessing students' learning preferences using } \\
\text { VARK }\end{array}$ \\
\hline $\begin{array}{l}\text { Allen LM III, Conder RL, Green } \\
\text { P, Cox DR. }\end{array}$ & Manual for the computerized assessment of response bias \\
\hline $\begin{array}{l}\text { Allen, G. J., Lerner, W. M. and } \\
\text { Hinrichsen, J. J. }\end{array}$ & $\begin{array}{l}\text { Study behaviors and their relationships to test anxiety and academic } \\
\text { performance }\end{array}$ \\
\hline $\begin{array}{l}\text { American Psychiatric } \\
\text { Association }\end{array}$ & The diagnostic and statistical manual of mental disorders: DSM-5 \\
\hline Ames, C. & Classrooms: goals, structures and student motivation \\
\hline Angelo TA, Cross KP. & Classroom Assessment Techniques: A Handbook for College Teachers \\
\hline APA & $\begin{array}{l}\text { Guidelines and principles for accreditation of programs in professional } \\
\text { psychology: Quick reference guide to doctoral programs }\end{array}$ \\
\hline Aquino LB. & $\begin{array}{l}\text { Study habits and attitudes of freshmen students: Implications for academic } \\
\text { intervention programs }\end{array}$ \\
\hline $\begin{array}{l}\text { Armbruster, B. B., Anderson, T. } \\
\text { H. }\end{array}$ & Research synthesis on study skills \\
\hline Bandura A. & Social cognitive theory of self-regulation \\
\hline $\begin{array}{l}\text { Bangert-Downs RL, Kulik JA, } \\
\text { Kulik CLC. }\end{array}$ & Effects of frequent classroom testing \\
\hline Barger JB. & How do undergraduate students study for anatomy and does it matter? \\
\hline $\begin{array}{l}\text { Barrash J, Stillman A, Anderson } \\
\text { SW, Uc Y, Dawson JD, Rizzo } \\
\text { M. }\end{array}$ & $\begin{array}{l}\text { Prediction of driving ability with neuropsychological tests: Demographic } \\
\text { adjustments diminish accuracy }\end{array}$ \\
\hline Barron, K., \& Harackiewicz, J. & Achievement goals and optimal motivation: testing multiple goal models \\
\hline Bartosz Gębka & $\begin{array}{l}\text { Psychological determinants of university students' academic performance: An } \\
\text { empirical study }\end{array}$ \\
\hline
\end{tabular}




\begin{tabular}{|c|c|}
\hline $\begin{array}{l}\text { Bashshur RL, Shannon G, } \\
\text { Krupinski EA, Grigsby J. }\end{array}$ & Sustaining and realizing the promise of telemedicine \\
\hline $\begin{array}{l}\text { Beate Schuster, Udo Rudolph, } \\
\text { Friedrich Forsterling }\end{array}$ & $\begin{array}{l}\text { What Determines Behavioral Decisions? Comparing the Role of Covariation } \\
\text { Information and Attributions }\end{array}$ \\
\hline $\begin{array}{l}\text { Benedict RH, Schretlen D, } \\
\text { Groninger L, Brandt J. }\end{array}$ & $\begin{array}{l}\text { Hopkins Verbal Learning Test-Revised: Normative data and analysis of } \\
\text { inter-form and test-retest reliability }\end{array}$ \\
\hline Benedict RH. & Brief visuospatial memory test_-revised: Professional manual \\
\hline $\begin{array}{l}\text { Benton AL, de Hamsher KS, } \\
\text { Varney NR, Spreen O. }\end{array}$ & Contributions to neuropsychological assessment: A clinical manual \\
\hline $\begin{array}{l}\text { Benton L, de Hamsher K, Sivan } \\
\text { A. }\end{array}$ & Multilingual Aphasia Examination \\
\hline $\begin{array}{l}\text { Bernard, R. M., Abrami, P. C., } \\
\text { Lou, Y., Borokhovski, E., Wade, } \\
\text { A.Wozney, L. }\end{array}$ & $\begin{array}{l}\text { How does distance education compare with classroom instruction? A } \\
\text { meta-analysis of the empirical literature }\end{array}$ \\
\hline $\begin{array}{l}\text { Berthelson L, Mulchan SS, } \\
\text { Odland AP, Miller LJ, } \\
\text { Mittenberg W. }\end{array}$ & False positive diagnosis of malingering due to the use of multiple effort tests. \\
\hline $\begin{array}{l}\text { Bette Davidowitz, Marissa } \\
\text { Rollnick, Marissa Rollnick }\end{array}$ & Adjustment of Under-Prepared Students to Tertiary Education \\
\hline $\begin{array}{l}\text { Bianchini KJ, Mathias CW, } \\
\text { Greve KW. }\end{array}$ & Symptom validity testing: A critical review \\
\hline Biggs, J. B. & Individual and group differences in study processes \\
\hline Biggs, J. B.. & The role of metalearning in study processes \\
\hline Biggs, J. B. & $\begin{array}{l}\text { Study process questionnaire manual. Student approaches to learning and } \\
\text { studying }\end{array}$ \\
\hline Biggs, J. B. & Dimensions of study behaviour: Another look at A.T.I. \\
\hline Bigler ED & Limitations with symptom validity, performance validity, and effort tests \\
\hline Bigler ED. & Symptom validity testing, effort, and neuropsychological assessment \\
\hline Bigler ED. & $\begin{array}{l}\text { Use of symptom validity tests and performance validity tests in disability } \\
\text { determinations }\end{array}$ \\
\hline $\begin{array}{l}\text { Bilder RM, Sugar CA, } \\
\text { Hellemann GS. }\end{array}$ & $\begin{array}{l}\text { Cumulative false positive rates given multiple performance validity tests: } \\
\text { Commentary on Davis and Millis (2014) and Larrabee (2014) }\end{array}$ \\
\hline $\begin{array}{l}\text { Binder LM, Iverson GL, Brooks } \\
\text { BL. }\end{array}$ & $\begin{array}{l}\text { To err is human: "Abnormal" neuropsychological scores and variability are } \\
\text { common in healthy adults }\end{array}$ \\
\hline $\begin{array}{l}\text { Binder LM, Villanueva MR, } \\
\text { Howieson D, Moore RT. }\end{array}$ & $\begin{array}{l}\text { The Rey AVLT recognition memory task measures motivational impairment } \\
\text { after mild head trauma }\end{array}$ \\
\hline
\end{tabular}




\begin{tabular}{|c|c|}
\hline Binder LM, Willis SC. & Assessment of motivation after financially compensable minor head trauma \\
\hline Binder LM. & Portland Digit Recognition Test manual—second edition \\
\hline Bjork R & Assessing our own competence: heuristics and illusions. \\
\hline Bjork R. & Memory and metamemory considerations in the training of human beings \\
\hline Bjork RA, Bjork EL. & $\begin{array}{l}\text { Making things hard on yourself, but in a good way: Creating desirable } \\
\text { difficulties to enhance learning }\end{array}$ \\
\hline Bodenheimer T, Sinsky C. & From triple to quadruple aim: care of the patient requires care of the provider \\
\hline Boekaerts M, Corno L. & Self-regulation in the classroom: a perspective on assessment and intervention \\
\hline Boekaerts, M. (1997). & $\begin{array}{l}\text { Self-regulated learning: a new concept embraced by researchers, policy } \\
\text { makers, educators, teachers and students }\end{array}$ \\
\hline Bollen, K. A. (1989). & Structural equations with latent variables \\
\hline $\begin{array}{l}\text { Boone KB, Lu P, Back C, King } \\
\text { C, Lee A, Philpott L, Shamieh } \\
\text { E, Warner-Chacon K. }\end{array}$ & $\begin{array}{l}\text { Sensitivity and specificity of the Rey Dot Counting Test in patients with } \\
\text { suspect effort and various clinical samples }\end{array}$ \\
\hline Boone KB, Lu P, Wen J. & $\begin{array}{l}\text { Comparison of various RAVLT scores in the detection of non-credible } \\
\text { memory performance }\end{array}$ \\
\hline Boone KB, Lu P. & Non-forced-choice effort measures \\
\hline Boone KB, Lu PH, Herzberg D. & The B Test manual \\
\hline Boone KB. & $\begin{array}{l}\text { Assessment of feigned cognitive impairment: A neuropsychological } \\
\text { perspective }\end{array}$ \\
\hline Boone KB. & Selection and use of multiple performance validity tests (PVTs) \\
\hline Boone KB. & $\begin{array}{l}\text { The need for continuous and comprehensive sampling of effort/response bias } \\
\text { during neuropsychological examinations }\end{array}$ \\
\hline Boud D, Molloy E. & Rethinking models of feedback for learning: the challenge of design \\
\hline Brandt J, Benedict RH. & Hopkins Verbal Learning Test, Revised: Professional manual \\
\hline Brandt J, van Gorp W. & $\begin{array}{l}\text { American Academy of Clinical Neuropsychology policy on the use of } \\
\text { non-doctoral-level personnel in conducting clinical neuropsychological } \\
\text { evaluations }\end{array}$ \\
\hline Breckler J, Joun D, Ngo H. & Learning styles of physiology students interested in the health professions. \\
\hline Brew, C. R. & Kolb's learning style instrument: sensitive to gender \\
\hline $\begin{array}{l}\text { Broekkamp, J., van } \\
\text { Hout-Wolters, B., Rijlaarsdam, } \\
\text { G., \& van den Bergh, H. }\end{array}$ & $\begin{array}{l}\text { Importance in instructional text: Teachers' and students' perceptions of task } \\
\text { demands }\end{array}$ \\
\hline
\end{tabular}




\begin{tabular}{|c|c|}
\hline Brophy, J. & Goal theorists should move on from performance goal \\
\hline $\begin{array}{l}\text { Brouwers, S. A., van Hemert, D. } \\
\text { A., Breugelmans, S. M. and van } \\
\text { de Vijver, F. J. R. }\end{array}$ & $\begin{array}{l}\text { A historical analysis of empirical studies published in the Journal of } \\
\text { Cross-Cultural Psychology 1970-2004 }\end{array}$ \\
\hline Brown, A. & $\begin{array}{l}\text { Metacognition, executive control, self-regulation and other more mysterious } \\
\text { mechanisms }\end{array}$ \\
\hline Browne, M. W., \& Cudeck, R. & Alternative ways of assessing model fit \\
\hline $\begin{array}{l}\text { Busch RM, Chelune GJ, Suchy } \\
\text { Y. }\end{array}$ & Using norms in neuropsychological assessment of the elderly \\
\hline $\begin{array}{l}\text { Bush SS, Ruff RM, Tröster AI, } \\
\text { Barth JT, Koffler SP, Pliskin } \\
\text { NH, Reynolds CR, Silver CH. }\end{array}$ & Symptom validity assessment: Practice issues and medical necessity \\
\hline $\begin{array}{l}\text { Butler A, Karpicke J, Roediger } \\
\text { H. }\end{array}$ & $\begin{array}{l}\text { Correcting a metacognitive error: feedback increases retention of } \\
\text { low-confidence correct responses }\end{array}$ \\
\hline Butler DL, Winne PH. & Feedback and self-regulated learning: a theoretical synthesis \\
\hline $\begin{array}{l}\text { C. Ward Struthers, Raymond P. } \\
\text { Perry }\end{array}$ & $\begin{array}{l}\text { Attributional style, attributional retraining, and inoculation against } \\
\text { motivational deficits }\end{array}$ \\
\hline Caballos, A. M. and Esteban, A. & Study skills and problem-solving strategies in Spanish students \\
\hline Cannon, R. and Newble, D. & $\begin{array}{l}\text { Handbook for teachers in universities and colleges: A guide to improving } \\
\text { teaching methods }\end{array}$ \\
\hline Cantwell, R. H., \& Moore, P. J. & $\begin{array}{l}\text { The development of measures of individual differences in self-regulatory } \\
\text { control and their relationship to academic performance }\end{array}$ \\
\hline Carone DA. & $\begin{array}{l}\text { Children with moderate/severe brain damage/dysfunction outperform adults } \\
\text { with mild-to-no brain damage on the Medical Symptom Validity Test }\end{array}$ \\
\hline $\begin{array}{l}\text { Carr M, Borkowski JG, } \\
\text { Maxwell SE. }\end{array}$ & Motivational components of underachievement \\
\hline Carroll, J. B. & Human cognitive abilities: a survey of factor analytic studies \\
\hline Carrow-Woolfolk E. & Comprehensive Assessment of Spoken Language \\
\hline Carver, C. S., \& Scheier, M. F. & Attention and self-regulation: A control theory approach to human behavior \\
\hline Case J, Gunstone R. & $\begin{array}{l}\text { Metacognitive development as a shift in approach to learning: an in-depth } \\
\text { study }\end{array}$ \\
\hline $\begin{array}{l}\text { Centre for Research in Distance } \\
\text { and Adult Learning }\end{array}$ & Distance and Open Virtual Learning Environment Scale (DOVILES) \\
\hline $\begin{array}{l}\text { Chafetz MD, Abrahams JP, } \\
\text { Kohlmaier J. }\end{array}$ & $\begin{array}{l}\text { Malingering on the Social Security disability consultative exam: A new rating } \\
\text { scale }\end{array}$ \\
\hline
\end{tabular}




\begin{tabular}{|c|c|}
\hline Chafetz MD, Underhill J. & Estimated costs of malingered disability \\
\hline Chafetz MD. & $\begin{array}{l}\text { Malingering on the Social Security disability consultative exam: Predictors } \\
\text { and base rates }\end{array}$ \\
\hline Chafetz MD. & The psychological consultative examination for Social Security disability \\
\hline $\begin{array}{l}\text { Chen, C., Stevenson, H. W., } \\
\text { Hayward, C. and Burgess, S. }\end{array}$ & Culture and academic achievement: Ethnic and cross-national differences \\
\hline Chris Masui, Erik Corte & $\begin{array}{l}\text { Learning to reflect and to attribute constructively as basic components of } \\
\text { self-regulated learning }\end{array}$ \\
\hline Claxton CS, Ralston Y. 1978. & Learning Styles: Their Impact on Teaching and Administration \\
\hline $\begin{array}{l}\text { Coffield F, Moseley D, Hall E, } \\
\text { Ecclestone K. }\end{array}$ & Should we be Using Learning Styles: What Research Has to Say to Practice \\
\hline Conder R, Allen L, Cox D. & Computerized Assessment of Response Bias test manual \\
\hline $\begin{array}{l}\text { Connie S.K. Poon, Derek J. } \\
\text { Koehler, }\end{array}$ & $\begin{array}{l}\text { Lay personality knowledge and dispositionist thinking: A } \\
\text { knowledge-activation framework }\end{array}$ \\
\hline Corno L. & The metacognitive control components of self-regulated learning \\
\hline Covington, M. V. & Motivated cognition \\
\hline Covington, M. V. & Strategic thinking and the fear of failure \\
\hline $\begin{array}{l}\text { Craik, F. I. M., \& Lockhart, R. } \\
\text { S. }\end{array}$ & Levels of processing: A framework for memory research \\
\hline Cross, D. R., \& Paris, S. G. & $\begin{array}{l}\text { Developmental an instructional analysis of children's metacognition and } \\
\text { reading comprehension }\end{array}$ \\
\hline $\begin{array}{l}\text { Crowe A, Dirks C, Wenderoth } \\
\text { MP. }\end{array}$ & $\begin{array}{l}\text { Biology in Bloom: implementing Bloom's taxonomy to enhance student } \\
\text { learning in biology }\end{array}$ \\
\hline $\begin{array}{l}\text { D'Ydewalle, G., Swerts, A., \& } \\
\text { De Corte, E. }\end{array}$ & Study time and test performance as a function of test expectations \\
\hline Daempfle PA. & $\begin{array}{l}\text { An analysis of the high attrition rates among first year college science, math, } \\
\text { and engineering majors }\end{array}$ \\
\hline $\begin{array}{l}\text { Darrell Anthony Luzzo, William } \\
\text { E. Hitchings, Paul Retish, } \\
\text { Andrew Shoemaker }\end{array}$ & $\begin{array}{l}\text { Evaluating Differences in College Students' Career Decision Making on the } \\
\text { Basis of Disability Status }\end{array}$ \\
\hline $\begin{array}{l}\text { David Le Foll, Olivier Rascle, } \\
\text { N.C. Higgins }\end{array}$ & $\begin{array}{l}\text { Attributional feedback-induced changes in functional and dysfunctional } \\
\text { attributions, expectations of success, hopefulness, and short-term persistence } \\
\text { in a novel spor }\end{array}$ \\
\hline Davidson A, Ritchie KL. & $\begin{array}{l}\text { The early bird catches the worm! The impact of chronotype and learning style } \\
\text { on academic success in university students }\end{array}$ \\
\hline
\end{tabular}




\begin{tabular}{|c|c|}
\hline Davis JJ, Millis SR. & $\begin{array}{l}\text { Examination of performance validity test failure in relation to number of tests } \\
\text { administered }\end{array}$ \\
\hline $\begin{array}{l}\text { Dean AC, Victor TL, Boone } \\
\text { KB, Arnold G. }\end{array}$ & The relationship of IQ to effort test performance \\
\hline $\begin{array}{l}\text { Dekker S, Lee NC, } \\
\text { Howard-Jones P, Jolles J. }\end{array}$ & $\begin{array}{l}\text { Neuromyths in education: Prevalence and predictors of misconceptions among } \\
\text { teachers }\end{array}$ \\
\hline Delis D, Kaplan E, Kramer J. & Delis-Kaplan executive function system \\
\hline Delis DC, Kramer JH, Kaplan E. & California Verbal Learning Test: CVLT-II; adult version; manual \\
\hline Dembo MH, Seli HP. & Students' resistance to change in learning strategies courses \\
\hline $\begin{array}{l}\text { Department of Health and Social } \\
\text { Care (UK) }\end{array}$ & Securing cyber resilience in health and care: Progress update \\
\hline DeRight J, Carone DA. & Assessment of effort in children: A systematic review \\
\hline $\begin{array}{l}\text { Dinsmore DL, Alexander PA, } \\
\text { Loughlin SM. }\end{array}$ & $\begin{array}{l}\text { Focusing the conceptual lens on metacognition, self-regulation, and } \\
\text { self-regulated learning }\end{array}$ \\
\hline Diseth, Å. and Martinsen, Ø. & $\begin{array}{l}\text { Approaches to learning, cognitive style, and motives as predictors of academic } \\
\text { achievement }\end{array}$ \\
\hline Donovan J, Radosevich D. & $\begin{array}{l}\text { A meta-analytic review of the distribution of practice effect: now you see it, } \\
\text { now you don't }\end{array}$ \\
\hline $\begin{array}{l}\text { Douglas Campbell, Andrew } \\
\text { Hussey }\end{array}$ & $\begin{array}{l}\text { Experimental evidence of the effects of an early intervention programme on } \\
\text { economics student achievement }\end{array}$ \\
\hline Dupeyrat, C., \& Martiné, C. & $\begin{array}{l}\text { Implicit theories of intelligence, goal orientation, cognitive engagement, and } \\
\text { achievement: a test of Dweck's model with returning to school adults }\end{array}$ \\
\hline Dweck, C. S. & Motivational processes affecting learning \\
\hline Dweck, C., \& Leggett, E. & A social-cognitive approach to motivation and personality \\
\hline $\begin{array}{l}\text { Edmonds EC, Delano-Wood L, } \\
\text { Galasko DR, Salmon DP, Bondi } \\
\text { MW. }\end{array}$ & $\begin{array}{l}\text { Subjective cognitive complaints contribute to misdiagnosis of mild cognitive } \\
\text { impairment }\end{array}$ \\
\hline Efklides, A., \& Petkaki, C. & Effects of mood on students' metacognitive experiences \\
\hline Eilam B, Reiter S. & $\begin{array}{l}\text { Long-term self-regulation of biology learning using standard junior high } \\
\text { school science curriculum }\end{array}$ \\
\hline Elliot, A. J. & Achievement goals and approach-avoidance motivation \\
\hline Elliot, A. J. & A conceptual history of the achievement goal construct \\
\hline Elliot, A. J., \& Church, M. A. & A hierarchical model of approach and avoidance achievement motivation \\
\hline Elliot, A. J., \& Murayama, K. & On the measurement of achievement goal: Critique, illustration, and \\
\hline
\end{tabular}




\begin{tabular}{|c|c|}
\hline & application \\
\hline Elliot,\& C. S. Dweck (Eds.) & Handbook of competence and motivation (pp. 52-72) \\
\hline Elliott R. & Executive functions and their disorders \\
\hline Elshout-Mohr, M. & Metacognition of learners in teaching-learning processes \\
\hline $\begin{array}{l}\text { Elshout-Mohr, M., Meijer, J., } \\
\text { van Daalen-Kapteijns, M. M., \& } \\
\text { Meeus, W. }\end{array}$ & Joint Research into the AILI (Awareness of Independent Learning Inventory) \\
\hline enko, C., \& Miles, K. M. & $\begin{array}{l}\text { Pursuing their own learning agenda: How mastery-oriented students } \\
\text { jeopardize their class performance }\end{array}$ \\
\hline Entwisle, N., \& McCune, V. & The conceptual bases of study strategy inventories \\
\hline Entwistle, $\mathrm{N}$. & Motivational factors in students' approaches to learning \\
\hline Entwistle, N. and Waterston, S. & Approaches to studying and levels of processing in university students \\
\hline Entwistle, N. J. & Understanding academic performance at university: A research retrospective \\
\hline Entwistle, N. J. and Ramsden, P. & Understanding student learning \\
\hline $\begin{array}{l}\text { Entwistle, N. J. and Waterston, } \\
\text { S. }\end{array}$ & Approaches to studying and levels of processing in university students \\
\hline Entwistle, N., \& Entwistle, D. & $\begin{array}{l}\text { Preparing for examinations: The interplay of memorizing and understanding, } \\
\text { and the development of knowledge objects }\end{array}$ \\
\hline Ertmer PA, Newby TJ. & The expert learner: strategic, self-regulated, and reflective \\
\hline $\begin{array}{l}\text { Etherton JL, Bianchini KJ, Ciota } \\
\text { MA, Greve KW. }\end{array}$ & $\begin{array}{l}\text { Reliable Digit Span is unaffected by laboratory-induced pain: Implications for } \\
\text { clinical use }\end{array}$ \\
\hline $\begin{array}{l}\text { Etherton JL, Bianchini KJ, } \\
\text { Greve KW, Ciota MA. }\end{array}$ & $\begin{array}{l}\text { Test of Memory Malingering performance is unaffected by laboratory-induced } \\
\text { pain: Implications for clinical use }\end{array}$ \\
\hline Etkin A, Gyurak A, O'Hara R. & A neurobiological approach to the cognitive deficits of psychiatric disorders \\
\hline Farias ST, Mungas D, Jagust W. & $\begin{array}{l}\text { Degree of discrepancy between self and other reported everyday functioning } \\
\text { by cognitive status: Dementia, mild cognitive impairment, and healthy elders }\end{array}$ \\
\hline $\begin{array}{l}\text { Faust D, Hart K, Guilmette T, } \\
\text { Arkes H. }\end{array}$ & Neuropsychologists' capacity to detect adolescent malingerers \\
\hline Felder RM, Brent R. & $\begin{array}{l}\text { The intellectual development of science and engineering students. Part 1: } \\
\text { models and challenges }\end{array}$ \\
\hline Feldt, R. C., \& Ray, M. & Effect of test expectancy on preferred study strategy use and test performance \\
\hline $\begin{array}{l}\text { Felicilda-Reynaldo RF, Cruz JP, } \\
\text { Bigley L, Adams K. }\end{array}$ & $\begin{array}{l}\text { Baccalaureate student nurses' study habits prior to admission to nursing } \\
\text { program: A descriptive qualitative study }\end{array}$ \\
\hline
\end{tabular}




\begin{tabular}{|c|c|}
\hline $\begin{array}{l}\text { Fenollar,P., Roman, S., \& } \\
\text { Cuestas, P. J. }\end{array}$ & $\begin{array}{l}\text { University students academic performance:An integrative conceptual } \\
\text { framework and empirical analysis }\end{array}$ \\
\hline FERPA & Family Educational Rights and Privacy Act \\
\hline Field A. & Discovering Statistics Using SPSS. 3rd Ed \\
\hline $\begin{array}{l}\text { Fitch ML, Drucker AJ, Norton } \\
\text { JA. }\end{array}$ & Frequent testing as a motivating factor in large lecture courses \\
\hline $\begin{array}{l}\text { Fitkov-Norris ED, Yeghiazarian } \\
\text { A. }\end{array}$ & Measuring study habits in higher education: The way forward? \\
\hline $\begin{array}{l}\text { Fitkov-Norris ED, Yeghiazarian } \\
\text { A. }\end{array}$ & Validation of VARK learning modalities questionnaire using Rasch analysis \\
\hline Fjortoft, N. F. & $\begin{array}{l}\text { Persistence in a distance learning program: A case in pharmaceutical } \\
\text { education }\end{array}$ \\
\hline Flavell, J. H. & $\begin{array}{l}\text { Metacognition and cognitive monitoring: a new area of } \\
\text { cognitive-developmental inquiry }\end{array}$ \\
\hline Flavell, J. H., \& Wellman, H. M. & Metamemory \\
\hline Fleming ND, Baume D. & Learning styles again: VARKing up the right tree! \\
\hline Fleming ND, Mills C. & Not another inventory, rather a catalyst for reflection \\
\hline Fleming ND. & $\begin{array}{l}\text { I'm different; not dumb. Modes of presentation (VARK) in the tertiary } \\
\text { classroom }\end{array}$ \\
\hline Fleming ND. & The case against learning styles: "There is no evidence..." \\
\hline Fleming ND. & Facts, fallacies and myths: VARK and learning preferences \\
\hline $\begin{array}{l}\text { Fleming, K., Ross, M., } \\
\text { Tollefson, N., \& Green, S. B. }\end{array}$ & $\begin{array}{l}\text { Teachers' choices of test-item formats for classes with diverse achievement } \\
\text { levels }\end{array}$ \\
\hline Foos, P. W. & Test performance as a function of expected form and difficulty \\
\hline Foos, P. W., \& Clark, M. C. & Learning from text: Effects of input order and expected test \\
\hline Fowler FJ Jr. & Improving Survey Questions: Design and Evaluation \\
\hline Frederick RI, Foster HG. & Multiple measures of malingering on a forced-choice test of cognitive ability \\
\hline Frederick RI. & Validity indicator profile manual \\
\hline Freedman D, Manly J. & $\begin{array}{l}\text { Use of normative data and measures of performance validity and symptom } \\
\text { validity in assessment of cognitive function }\end{array}$ \\
\hline Funahashi S. & Neuronal mechanisms of executive control by the prefrontal cortex \\
\hline $\begin{array}{l}\text { Gadzella, B. M., Williamson, J. } \\
\text { D. }\end{array}$ & Study skills, self-concept, and academic achievement \\
\hline
\end{tabular}




\begin{tabular}{|c|c|}
\hline $\begin{array}{l}\text { Garavalia L, Scheuer D, Carroll } \\
\text { C. }\end{array}$ & $\begin{array}{l}\text { Comparative analysis of first- and third-year pharmacy students' perceptions } \\
\text { of student-regulated learning strategies and motivation }\end{array}$ \\
\hline $\begin{array}{l}\text { Garcia Duncan, T., \& } \\
\text { McKeachie, W. J. }\end{array}$ & The making of the motivated strategies for learning questionnaire \\
\hline Gardner, $\mathrm{H}$. & Frames of mind: the theory of multiple intelligences \\
\hline $\begin{array}{l}\text { Gasiewski JA, Eagan MK, } \\
\text { Garcia GA, Hurtado S, Chang } \\
\text { MJ. }\end{array}$ & $\begin{array}{l}\text { From gatekeeping to engagement: a multicontextual, mixed method study of } \\
\text { student academic engagement in introductory STEM courses }\end{array}$ \\
\hline Gast J, Hart KJ. & The performance of juvenile offenders on the Test of Memory Malingering \\
\hline $\begin{array}{l}\text { Gervais RO, Rohling ML, Green } \\
\text { P, Ford W. }\end{array}$ & $\begin{array}{l}\text { A comparison of WMT, CARB, and TOMM failure rates in non-head injury } \\
\text { disability claimants }\end{array}$ \\
\hline Gibson, C. C. & The distance learner in context \\
\hline $\begin{array}{l}\text { Ginger Clark, John J. Horan, } \\
\text { Amy Tompkins-Bjorkman, } \\
\text { Theresa Kovalski, Gail Hackett, }\end{array}$ & Interactive Career Counseling on the Internet \\
\hline Goldman, R. D. and Warren, R. & $\begin{array}{l}\text { Discriminant analysis of study strategies connected with college grade success } \\
\text { in different major fields }\end{array}$ \\
\hline Goodglass H, Kaplan E. & Boston diagnostic aphasia examination \\
\hline Goudsmit, E. & $\begin{array}{l}\text { Interviews concerning effort investment and strategy use for Introduction to } \\
\text { Psychology }\end{array}$ \\
\hline Grant, H., \& Dweck, C. S. & Clarifying achievement goals and their impact \\
\hline $\begin{array}{l}\text { Graue LO, Berry DT, Clark JA, } \\
\text { Sollman MJ, Cardi M, Hopkins } \\
\text { J, Werline D. }\end{array}$ & $\begin{array}{l}\text { Identification of feigned mental retardation using the new generation of } \\
\text { malingering detection instruments: Preliminary findings }\end{array}$ \\
\hline Green P, Allen L, Astner K. & $\begin{array}{l}\text { The Word Memory Test: A user's guide to the oral and computer-administered } \\
\text { form }\end{array}$ \\
\hline Green P. & Green's Memory Complaints Inventory (MCI) \\
\hline Green P. & Manual for Nonverbal Medical Symptom Validity Test \\
\hline $\begin{array}{l}\text { Green, S. B., Salkind, N. J., \& } \\
\text { Akey, T. M. }\end{array}$ & Using SPSS for Windows: Analyzing and understanding data (2nd ed.) \\
\hline $\begin{array}{l}\text { Greiffenstein M, Gervais R, } \\
\text { Baker WJ, Artiola L, Smith H. }\end{array}$ & $\begin{array}{l}\text { Symptom validity testing in medically unexplained pain: A chronic regional } \\
\text { pain syndrome type } 1 \text { case series }\end{array}$ \\
\hline $\begin{array}{l}\text { Greiffenstein MF, Baker WJ, } \\
\text { Gola T. }\end{array}$ & Validation of malingered amnesia measures with a large clinical sample \\
\hline Greve KW, Bianchini KJ. & $\begin{array}{l}\text { Setting empirical cutoffs on psychometric indicators of negative response } \\
\text { bias: A methodological commentary with recommendations }\end{array}$ \\
\hline
\end{tabular}




\begin{tabular}{|c|c|}
\hline $\begin{array}{l}\text { Griffin GA, Normington J, May } \\
\text { R, Glassmire D. }\end{array}$ & Assessing dissimulation among Social Security disability income claimants \\
\hline Gronwall D. & Paced auditory serial-addition task: A measure of recovery from concussion \\
\hline Grote LG, Hook JN. & Forced-choice recognition tests of malingering \\
\hline Groth-Marnat G. & Handbook of psychological assessment \\
\hline $\begin{array}{l}\text { Hadwin AF, Winne PH, } \\
\text { Stockley DB, Nesbit JC, } \\
\text { Woszczyna C. }\end{array}$ & Context moderates students' self-reports about how they study \\
\hline Hakstian, A. R. & $\begin{array}{l}\text { The effects of the type of examination anticipated on test preparation and } \\
\text { performance }\end{array}$ \\
\hline Hammill DD, Larsen SC. & Test of written language: Examiner's manual \\
\hline $\begin{array}{l}\text { Hampson NE, Kemp S, } \\
\text { Coughlan AK, Moulin CJ, } \\
\text { Bhakta BB. }\end{array}$ & Applied Neuropsychology: Adult \\
\hline $\begin{array}{l}\text { Harackiewicz, J. M., Barron, K. } \\
\text { E., \& Elliot, A. J. }\end{array}$ & $\begin{array}{l}\text { Rethinking achievement goals: when are they adaptive for college students } \\
\text { and why }\end{array}$ \\
\hline $\begin{array}{l}\text { Harackiewicz, J. M., Barron, K. } \\
\text { E., Tauer, J. M., Carter, S. M., \& } \\
\text { Elliot, A. J. }\end{array}$ & $\begin{array}{l}\text { Short-term and long-term consequences of achievement goals: Predicting } \\
\text { interest and performance over time }\end{array}$ \\
\hline $\begin{array}{l}\text { Harakiewicz, J., Barron, K., } \\
\text { Pintrich, P., Elliot, A., \& Thrash, } \\
\text { T. }\end{array}$ & Revision of achievement goal theory: necessary and illuminating. \\
\hline Hawk TF, Shah AJ. & Using learning style instruments to enhance student learning \\
\hline Hayes, A. F. & $\begin{array}{l}\text { PROCESS: A versatile computational tool for observed variable mediation, } \\
\text { moderation, and conditional process modeling }\end{array}$ \\
\hline $\begin{array}{l}\text { Haynes, N. M., Comer, J. P. and } \\
\text { Hamilton-Lee, M. }\end{array}$ & $\begin{array}{l}\text { Gender and achievement status differences on learning factors among black } \\
\text { high school students }\end{array}$ \\
\hline $\begin{array}{l}\text { Haynes, N. M., Comer, J. P., } \\
\text { Hamilton-Lee, M., Boger, J. and } \\
\text { Joyner, E. }\end{array}$ & $\begin{array}{l}\text { Differences among high, average, and low high school achievers on the } \\
\text { Learning and Study Strategies Inventory }\end{array}$ \\
\hline $\begin{array}{l}\text { Heaton RK, Grant I, Matthews } \\
\text { CG. }\end{array}$ & $\begin{array}{l}\text { Comprehensive norms for an expanded Halstead-Reitan Battery: } \\
\text { Demographic corrections }\end{array}$ \\
\hline $\begin{array}{l}\text { Heaton RK, Smith HH, Lehman } \\
\text { RA, Vogt AT. }\end{array}$ & Prospects for faking believable deficits on neuropsychological testing \\
\hline Heaton RK, Taylor M, Manly J. & $\begin{array}{l}\text { Demographic effects and demographically corrected norms with the WAIS-III } \\
\text { and WMS-III }\end{array}$ \\
\hline Heaton RK. & Wisconsin Card Sorting Test: Computer version 2 \\
\hline
\end{tabular}




\begin{tabular}{|c|c|}
\hline $\begin{array}{l}\text { Heilbronner RL, Sweet JJ, } \\
\text { Morgan JE, Larrabee GJ, Millis } \\
\text { SR. }\end{array}$ & Conference Participants \\
\hline $\begin{array}{l}\text { Higginson CI, Lanni K, Sigvardt } \\
\text { KA, Disbrow EA. }\end{array}$ & $\begin{array}{l}\text { The contribution of trail making to the prediction of performance-based } \\
\text { instrumental activities of daily living in Parkinson's disease without dementia }\end{array}$ \\
\hline Hiscock M, Hiscock CK. & Refining the forced-choice method for the detection of malingering \\
\hline $\begin{array}{l}\text { HNS (Houston } \\
\text { Neuropsychological Society). }\end{array}$ & $\begin{array}{l}\text { The Houston Conference on Specialty Education and Training in Clinical } \\
\text { Neuropsychology policy statement }\end{array}$ \\
\hline $\begin{array}{l}\text { Höffler TN, Koć - Januchta M, } \\
\text { Leutner D. }\end{array}$ & $\begin{array}{l}\text { More evidence for three types of cognitive style: Validating the object-spatial } \\
\text { imagery and verbal questionnaire using eye tracking when learning with texts } \\
\text { and pictures }\end{array}$ \\
\hline Holdnack JA, Drozdick LW. & $\begin{array}{l}\text { Advanced clinical solutions for WAIS-IV and WMS-IV: Clinical and } \\
\text { interpretive manual }\end{array}$ \\
\hline $\begin{array}{l}\text { McGrew S, Smith M, } \\
\text { Breakstone J, Ortega T, } \\
\text { Wineburg S. }\end{array}$ & Improving university students' web savvy: An intervention study \\
\hline $\begin{array}{l}\text { Theis D, Sauerwein M, Fischer } \\
\text { N. }\end{array}$ & $\begin{array}{l}\text { Perceived quality of instruction: The relationship among indicators of } \\
\text { students' basic needs, mastery goals, and academic achievement }\end{array}$ \\
\hline Hertel S, Karlen Y. & $\begin{array}{l}\text { Implicit theories of self-regulated learning: Interplay with students' } \\
\text { achievement goals, learning strategies }\end{array}$ \\
\hline $\begin{array}{l}\text { Palsola M, Renko E, Kostamo } \\
\text { K, Lorencatto F, Hankonen N. }\end{array}$ & $\begin{array}{l}\text { Thematic analysis of acceptability and fidelity of engagement for behaviour } \\
\text { change interventions: The Let's Move It intervention interview study }\end{array}$ \\
\hline $\begin{array}{l}\text { Frie K, Hartmann-Boyce J, Jebb } \\
\text { SA, Aveyard P. }\end{array}$ & $\begin{array}{l}\text { Effectiveness of a self-regulation intervention for weight loss: A randomized } \\
\text { controlled trial }\end{array}$ \\
\hline O’Connor KJ. & Should I Give the Exam Before or After the Break? \\
\hline Balch WR. & Practice versus Review Exams and Final Exam Performance \\
\hline Phan HP. & $\begin{array}{l}\text { Empirical model and analysis of mastery and performance-approach goals: A } \\
\text { developmental approach. }\end{array}$ \\
\hline Huang C. & Achievement goals and achievement emotions: A meta-analysis \\
\hline Watkins D. & $\begin{array}{l}\text { Teachers as scholars of their students' conceptions of learning: a Hong Kong } \\
\text { investigation }\end{array}$ \\
\hline $\begin{array}{l}\text { Meece JL, Anderman EM, } \\
\text { Anderman LH. }\end{array}$ & Classroom goal structure, student motivation, and academic achievement \\
\hline Tapola A, Niemvirta M. & $\begin{array}{l}\text { The role of achievement goal orientations in students' perceptions of and } \\
\text { preferences for classroom environment }\end{array}$ \\
\hline Cano F, Berbén ABG. & $\begin{array}{l}\text { University students' achievement goals and approaches to learning in } \\
\text { mathematics }\end{array}$ \\
\hline
\end{tabular}




\begin{tabular}{|c|c|}
\hline Advokat C, Lane SM, Luo C. & $\begin{array}{l}\text { College students with and without ADHD: comparison of self-report of } \\
\text { medication usage, study habits, and academic achievement }\end{array}$ \\
\hline $\begin{array}{l}\text { Burgoon JM, Meece JL, Granger } \\
\text { NA. }\end{array}$ & $\begin{array}{l}\text { Self-efficacy's influence on student academic achievement in the medical } \\
\text { anatomy curriculum }\end{array}$ \\
\hline Shek DTL, Cheung BPM. & Developmental issues of university students in Hong Kong \\
\hline $\begin{array}{l}\text { Shek DTL, Yu L, Ma CMS, Sun } \\
\text { RCF, Liu TT. }\end{array}$ & $\begin{array}{l}\text { Development of a credit-bearing service leadership subject for university } \\
\text { students in Hong Kong }\end{array}$ \\
\hline Fredieu JR, Snyder CW. & $\begin{array}{l}\text { Positive impact of a master of science in applied anatomy program on } \\
\text { USMLE Step } 1 \text { performance }\end{array}$ \\
\hline Snyder JJ, Carter BE, Wiles JR. & $\begin{array}{l}\text { Implementation of the peer-led team-learning instructional model as a stopgap } \\
\text { measure improves student achievement for students opting out of laboratory }\end{array}$ \\
\hline $\begin{array}{l}\text { Stanton JD, Neider XN, } \\
\text { Gallegos IJ, Clark NC. }\end{array}$ & $\begin{array}{l}\text { Differences in metacognitive regulation in introductory biology students: } \\
\text { when prompts are not enough }\end{array}$ \\
\hline Ghosh SJ. & $\begin{array}{l}\text { Cadaveric dissection as an educational tool for anatomical sciences in the } 21 \mathrm{st} \\
\text { century }\end{array}$ \\
\hline $\begin{array}{l}\text { Langlois J, Bellemare C, } \\
\text { Toulouse J, Wells GA. }\end{array}$ & Spatial abilities and anatomy knowledge assessment: A systematic review \\
\hline $\begin{array}{l}\text { Choi-Lundberg DL, Cuellar } \\
\text { WA, Williams AM. }\end{array}$ & $\begin{array}{l}\text { Online dissection audio-visual resources for human anatomy: Undergraduate } \\
\text { medical students' usage and learning outcomes }\end{array}$ \\
\hline Panadero E. & $\begin{array}{l}\text { A Review of Self-regulated Learning: Six Models and Four Directions for } \\
\text { Research }\end{array}$ \\
\hline $\begin{array}{l}\text { van Houten-Schat MA, } \\
\text { Berkhout JJ, van Dijk N, } \\
\text { Endedijk MD, Jaarsma ADC, } \\
\text { Diemers AD. }\end{array}$ & Self-regulated learning in the clinical context: a systematic review \\
\hline $\begin{array}{l}\text { Duckworth AL, Taxer JL, } \\
\text { Eskreis-Winkler L, Galla BM, } \\
\text { Gross JJ. }\end{array}$ & Self-Control and Academic Achievement \\
\hline $\begin{array}{l}\text { Kuhbandner C, Emmerdinger } \\
\text { KJ. }\end{array}$ & $\begin{array}{l}\text { Do students really prefer repeated rereading over testing when studying } \\
\text { textbooks? A reexamination }\end{array}$ \\
\hline $\begin{array}{l}\text { Datar MV, Holmes ER, Adams } \\
\text { AJ, Stolpe SF. }\end{array}$ & Student pharmacists' perceptions of community pharmacy residency programs \\
\hline $\begin{array}{l}\text { Oyler DR, Romanelli F, Piascik } \\
\text { P, Cain J. }\end{array}$ & Practical Insights for the Pharmacist Educator on Student Engagement \\
\hline Jacob B, Peasah S. & $\begin{array}{l}\text { Evaluation of first year student pharmacists' perceptions of the } \\
\text { pharmaceutical industry }\end{array}$ \\
\hline Katoue MG, Ker J. & $\begin{array}{l}\text { Pharmacists' experiences and perceptions about simulation use for learning } \\
\text { and development of clinical skills in Kuwait }\end{array}$ \\
\hline
\end{tabular}




\begin{tabular}{|c|c|}
\hline Mccombs BL. & The Role of the Self-System in Self-Regulated Learning \\
\hline $\begin{array}{l}\text { Weinstein CE, Zimmermann } \\
\text { SA, Palmer DR. }\end{array}$ & Assessing learning strategies: The design and development of the LASSI \\
\hline $\begin{array}{l}\text { Weinstein CE, Palmer DR, } \\
\text { Shulte AC, Rooks EM. }\end{array}$ & Learning and Study Strategies Inventory 2 nd Edition (LASSI) \\
\hline Neugebauer SR. & $\begin{array}{l}\text { A daily diary study of reading motivation inside and outside of school: A } \\
\text { dynamic approach to motivation to read }\end{array}$ \\
\hline $\begin{array}{l}\text { Schweizer F, Wüstenberg S, } \\
\text { Greiff S. }\end{array}$ & $\begin{array}{l}\text { Validity of the MicroDYN approach: Complex problem solving predicts } \\
\text { school grades beyond working memory capacity }\end{array}$ \\
\hline $\begin{array}{l}\text { Fujisawa KK, Wadsworth SJ, } \\
\text { Jajihana S, Olson RK, DeFries } \\
\text { JC, Byrne B, Ando J. }\end{array}$ & A multivariate twin study of early literacy in Japanese kana \\
\hline $\begin{array}{l}\text { Raufelder D, Drury K, Jagenow } \\
\text { D, Hoferichter F, Bukoski W. }\end{array}$ & $\begin{array}{l}\text { Development and validation of the Relationship and Motivation (REMO) } \\
\text { scale to assess students' perceptions of peers and teachers as motivators in } \\
\text { adolescence }\end{array}$ \\
\hline $\begin{array}{l}\text { Balsamo M, Lauriola M, } \\
\text { Saggino A. }\end{array}$ & Work values and college major choice \\
\hline $\begin{array}{l}\text { Luwel K, Foustana A, Onghena } \\
\text { P, Verschaffel L. }\end{array}$ & $\begin{array}{l}\text { The role of verbal and performance intelligence in children's strategy } \\
\text { selection and execution }\end{array}$ \\
\hline Hofmann B. & Biases and imperatives in handling medical technology \\
\hline Griffin C, Jones J, Kilgore KL. & $\begin{array}{l}\text { A Qualitative Study of Student Teachers' Experiences with Collaborative } \\
\text { Problem Solving }\end{array}$ \\
\hline Stout D, Ruble TL. & A reexamination of accounting student learning styles \\
\hline Lpez CL. & Assessment of student learning: challenges and strategies \\
\hline $\begin{array}{l}\text { Constantino-Conzález MdlA, } \\
\text { Suthers D. }\end{array}$ & Coaching collaboration in a computer-mediated learning environment \\
\hline Herkert J. & Collaborative learning in engineering ethics \\
\hline $\begin{array}{l}\text { Terenzini P, Cabrera A, Colbeck } \\
\text { C, Parente JM, Bjorklund SA. }\end{array}$ & $\begin{array}{l}\text { Collaborative Learning vs. Lecture/Discussion: Students' Reported Learning } \\
\text { Gains }\end{array}$ \\
\hline Leithner A. & Do Student Learning Styles Translate to Different “Testing Styles”? \\
\hline Evans C, Mujis D, Tomlinson D. & $\begin{array}{l}\text { Engaged student learning. High Impact strategies to enhance student } \\
\text { achievement }\end{array}$ \\
\hline Walberg H, Wallace $\mathrm{T}$. & Family Programs for Academic Learning \\
\hline Lee $\mathrm{K}$. & Online Collaborative Case Study Learning \\
\hline Vermunt J, Vermetten YJM. & Patterns in Student Learning: Relationships Between Learning Strategies, \\
\hline
\end{tabular}




\begin{tabular}{|c|c|}
\hline & Conceptions of Learning, and Learning Orientations \\
\hline Newton FB. & Principles and strategies for enhancing student learning \\
\hline Dale C. & Strategies for using podcasting to support student learning. \\
\hline Perrine JL. & Strategies to boost RN retention. \\
\hline $\begin{array}{l}\text { Dressier S, Cedercreutz K, } \\
\text { Pacheco A. }\end{array}$ & $\begin{array}{l}\text { Strengthening Curriculum through Student Learning Outcome Assessment in } \\
\text { Experimental Learning }\end{array}$ \\
\hline $\begin{array}{l}\text { Stillman S, Stillman PE, } \\
\text { Martínez, Freedman J, Jensen A, } \\
\text { Leet C. }\end{array}$ & $\begin{array}{l}\text { Strengthening social emotional learning with student, teacher, and schoolwide } \\
\text { assessments. }\end{array}$ \\
\hline Kolluru S, Varughese J. & $\begin{array}{l}\text { Structured academic discussions through an online education-specific } \\
\text { platform to improve Pharm.D. students learning outcomes. }\end{array}$ \\
\hline Hansen JW. & Student Cognitive Styles in Postsecondary Technology Programs. \\
\hline $\begin{array}{l}\text { Brown RD, Hallett ME, Stoltz } \\
\text { R. }\end{array}$ & Student learning styles in landscape architecture education \\
\hline Mather J, Champagne A. & $\begin{array}{l}\text { Student Learning Styles/Strategies and Professors' Expectations: Do Thety } \\
\text { Match? }\end{array}$ \\
\hline Dawson V, Venville G. & $\begin{array}{l}\text { Teaching Strategies for Developing Students' Argumentation Skills About } \\
\text { Socioscientific Issues in High School Genetics }\end{array}$ \\
\hline Hsieh P, Dwyer F. & $\begin{array}{l}\text { The Instructional Effect of Online Reading Strategies and Learning Styles on } \\
\text { Student Academic Achievement }\end{array}$ \\
\hline Cuthbert P. & The student learning process: Learning styles or learning approaches? \\
\hline Desselle S. & $\begin{array}{l}\text { The use of Twitter to facilitate engagement and reflection in a constructionist } \\
\text { learning environment. }\end{array}$ \\
\hline $\begin{array}{l}\text { Letassy NA, Fugate S, Medina } \\
\text { M, Stroup J, Britton M. }\end{array}$ & $\begin{array}{l}\text { Using team-based learning in an endocrine module taught across two } \\
\text { campuses. }\end{array}$ \\
\hline Tracey WR. & Programing -- Evaluating Achievements \\
\hline Cervone BT. & Student Attitudes toward Studying History \\
\hline Yip MCW. & $\begin{array}{l}\text { Learning strategies and their relationships to academic performance of high } \\
\text { school students in Hong Kong }\end{array}$ \\
\hline $\begin{array}{l}\text { Papinczak T, Peterson R, Babri } \\
\text { AS, Ward K, Kippers V, } \\
\text { Wilkinson D. }\end{array}$ & Using student-generated questions for student-centred assessment \\
\hline $\begin{array}{l}\text { Rothberg SJ, Lamb FM, Willis } \\
\text { L. }\end{array}$ & $\begin{array}{l}\text { Computer-assisted learning in UL engineering degree programmes: lessons } \\
\text { learning from an extensive case study programme }\end{array}$ \\
\hline Yip MCW. & The linkage among academic performance, learning strategies and \\
\hline
\end{tabular}




\begin{tabular}{|c|c|}
\hline & self-efficacy of Japanese university students: a mixed-method approach \\
\hline Kokkinos T, Gakis P. & Student teachers' differentiated teaching practices for high-achieving students \\
\hline King A. & $\begin{array}{l}\text { Facilitating Elaborative Learning through Guided Student-Generated } \\
\text { Questioning }\end{array}$ \\
\hline $\begin{array}{l}\text { Hulleman CS, Durik AM, } \\
\text { Schweigert SA, Harackiewicz } \\
\text { JM. }\end{array}$ & Task values, achievement goals, and interest: An integrative analysis. \\
\hline $\begin{array}{l}\text { Hulleman CS, Schrager SM, } \\
\text { Bodmann SM, \& Harackiewic } \\
\text { JM. }\end{array}$ & $\begin{array}{l}\text { A meta-analytic review of achievement goal measures: Different labels for the } \\
\text { same con-structs or different constructs with similar labels? }\end{array}$ \\
\hline Hurley KE, Deal WP. & $\begin{array}{l}\text { Assessment instruments measuring malingering used with individuals who } \\
\text { have mental retardation: Potential problems and issues. }\end{array}$ \\
\hline $\begin{array}{l}\text { Husmann PR, O'Loughlin VD, } \\
\text { Braun MW. }\end{array}$ & $\begin{array}{l}\text { Quantitative and qualitative changes in teaching histology by means of virtual } \\
\text { microscopy in an introductory course in human anatomy. }\end{array}$ \\
\hline Iverson GL, Franzen MD. & Using multiple objective memory procedures to detect simulated malingering. \\
\hline Rawson KA, Dunlosky J. & $\begin{array}{l}\text { Optimizing schedules of retrieval practice for durable and efficient learning: } \\
\text { how much is enough? }\end{array}$ \\
\hline Meyer JHF, Cliff AF, Dunne TT. & Impressions of disadvantage: II-Monitoring and assisting the student at risk \\
\hline Jacobs JE, Paris SG. & $\begin{array}{l}\text { Children's metacognition about reading: issues in definition, measurement and } \\
\text { instruction }\end{array}$ \\
\hline James S, D'Amore A, Thomas T. & $\begin{array}{l}\text { Learning preferences of first year nursing and midwifery students: Utilising } \\
\text { VARK. }\end{array}$ \\
\hline $\begin{array}{l}\text { Jelicic M, Merckelbach H, } \\
\text { Candel I, Geraets E. }\end{array}$ & $\begin{array}{l}\text { Detection of feigned cognitive dysfunction using special malinger tests: A } \\
\text { simulation study in naïve and coached malingerers }\end{array}$ \\
\hline Jensen PA, Barron JN. & Midterm and first-exam grades predict final grades in biology courses \\
\hline $\begin{array}{l}\text { Hamm JM, Perry RP, } \\
\text { Chipperfield JG, Murayama K, } \\
\text { Weiner B. }\end{array}$ & $\begin{array}{l}\text { Attribution-based motivation treatment efficacy in an online learning } \\
\text { environment for students who differ in cognitive elaboration }\end{array}$ \\
\hline Hattie J, Biggs J, Purdie N. & $\begin{array}{l}\text { Effects of Learning Skills Interventions on Student Learning: A } \\
\text { Meta-Analysis }\end{array}$ \\
\hline Horan JJ. & Violence Prevention \\
\hline $\begin{array}{l}\text { Johnson-Greene D, Brooks L, } \\
\text { Ference T. }\end{array}$ & $\begin{array}{l}\text { Relationship between performance validity testing, disability status, and } \\
\text { somatic complaints in patients with fibromyalgia }\end{array}$ \\
\hline Jöreskog, K. G., \& Sörbom, D. & LISREL 8 user guide ( 2 nd edition) \\
\hline $\begin{array}{l}\text { Jungnickel P, Kelley K, Hammer } \\
\text { D, Haines S, Marlowe K. }\end{array}$ & Addressing competencies for the future in the professional curriculum \\
\hline
\end{tabular}




\begin{tabular}{|c|c|}
\hline Bridges KR. & $\begin{array}{l}\text { Using attributional style to predict academic performance: how does it } \\
\text { compare to traditional methods? }\end{array}$ \\
\hline $\begin{array}{l}\text { Kaplan E, Goodglass H, } \\
\text { Weintraub S. }\end{array}$ & Boston Naming Test. \\
\hline Kaplan, A., \& Middleton, M. & $\begin{array}{l}\text { Performance-approach goals: Good for what, for whom, under what } \\
\text { circumstances, and at what cost? }\end{array}$ \\
\hline Karpicke J, Roediger H. & $\begin{array}{l}\text { Expanding retrieval practice promotes short-term retention, but equally spaced } \\
\text { retrieval enhances long-term retention }\end{array}$ \\
\hline Karpicke J, Roediger H. & Repeated retrieval during learning is the key to long-term retention \\
\hline Karpicke J, Roediger H. & The critical importance of retrieval for learning \\
\hline Karpicke J. & $\begin{array}{l}\text { Metacognitive control and strategy selection: deciding to practice retrieval } \\
\text { during learning }\end{array}$ \\
\hline Karpicke JD, Bauernschmidt A. & $\begin{array}{l}\text { Spaced retrieval: Absolute spacing enhances learning regardless of relative } \\
\text { spacing }\end{array}$ \\
\hline Kryza K. & $\begin{array}{l}\text { Practical Strategies for Developing Executive Functioning Skills for ALL } \\
\text { Learners in the Differentiated Classroom }\end{array}$ \\
\hline Kember D, Gow L. & Cultural specificity of approaches to study \\
\hline Ichimura K, Kusumi T & The influence of giving up and the timing of intervention on task persistence. \\
\hline Kepple G. & A reconsideration of the extinction-recovery theory \\
\hline Kiewra KA. & How classroom teachers can help students learn and teach them how to learn \\
\hline Killgore WD, DellaPietra L. & $\begin{array}{l}\text { Using the WMS-III to detect malingering: Empirical validation of the rarely } \\
\text { missed index (RMI) }\end{array}$ \\
\hline Kim RH, Gilbert T, Ristig K. & $\begin{array}{l}\text { The effect of surgical resident learning style preferences on American Board } \\
\text { of Surgery In-training Examination scores }\end{array}$ \\
\hline $\begin{array}{l}\text { Kim RH, Kurtzman SH, Collier } \\
\text { AN, Shabahang MM. }\end{array}$ & $\begin{array}{l}\text { The learning preferences of applicants who interview for general surgery } \\
\text { residency: A multi-institutional study. }\end{array}$ \\
\hline $\begin{array}{l}\text { King PM, Brown MK, Lindsay } \\
\text { NK, Vanhecke JR. }\end{array}$ & Liberal arts student learning outcomes: an integrated approach \\
\hline Kirkwood M. & $\begin{array}{l}\text { Validity testing in pediatric populations; Presentation to IOM Committee on } \\
\text { Psychological Testing, Including Validity Testing, for Social Security } \\
\text { Administration }\end{array}$ \\
\hline $\begin{array}{l}\text { Kirkwood MW, Yeates KO, } \\
\text { Randolph C, Kirk JW. }\end{array}$ & $\begin{array}{l}\text { The implications of symptom validity test failure for ability-based test } \\
\text { performance in a pediatric sample. }\end{array}$ \\
\hline Kitsantas A. & Test preparation and performance: a self-regulatory analysis. \\
\hline
\end{tabular}




\begin{tabular}{|c|c|}
\hline Kline, R. B. & Principles and practice of structural equation modeling (2nd edition). \\
\hline Kolers P, Roediger H. & Procedures of mind \\
\hline Kollöffel B. & $\begin{array}{l}\text { Exploring the relation between visualizer-verbalizer cognitive styles and } \\
\text { performance with visual or verbal learning material }\end{array}$ \\
\hline $\begin{array}{l}\text { Koopman, M., Den Brok, P., } \\
\text { Beijaard, D., \& Teune, P. }\end{array}$ & $\begin{array}{l}\text { Learning processes of students in pre-vocational secondary education: } \\
\text { Relations between goal orientations,information processing strategies and } \\
\text { development of conceptual knowledge }\end{array}$ \\
\hline Kornell N, Bjork R. & The promise and perils of self-regulated study \\
\hline $\begin{array}{l}\text { Kozlowski SWJ, Gully SM, } \\
\text { Brown KG, Salas E, Smith EM, } \\
\text { Nason ER. }\end{array}$ & $\begin{array}{l}\text { Effects Of training goals and goal orientation traits on multidimensional } \\
\text { training outcomes and performance adaptability }\end{array}$ \\
\hline $\begin{array}{l}\text { Kraemer DJ, Hamilton RH, } \\
\text { Messing SB, DeSantis JH, } \\
\text { Thompson-Schill SL. }\end{array}$ & Cognitive style, cortical stimulation, and the conversion hypothesis \\
\hline $\begin{array}{l}\text { Kumar VK, Rabinsky L, Pandey } \\
\text { TJ. }\end{array}$ & Test mode, test instructions, and retention. \\
\hline Kvedar J, Coye MJ, Everett W. & $\begin{array}{l}\text { Connected health: a review of technologies and strategies to improve patient } \\
\text { care with telemedicine and telehealth }\end{array}$ \\
\hline $\begin{array}{l}\text { L. E., Stanley, L. J., Bynum, B. } \\
\text { H., \& Lance, C. E. }\end{array}$ & $\begin{array}{l}\text { Examining the construct validity of mastery-avoidance achievement goals: A } \\
\text { meta-analysis }\end{array}$ \\
\hline Larrabee GJ. & $\begin{array}{l}\text { Assessment of malingering. In: Larrabee GJ, editor. Forensic } \\
\text { neuropsychology: A scientific approach }\end{array}$ \\
\hline Larrabee GJ. & $\begin{array}{l}\text { Detection of malingering using atypical performance patterns on standard } \\
\text { neuropsychological tests }\end{array}$ \\
\hline Larrabee GJ. & $\begin{array}{l}\text { False-positive rates associated with the use of multiple performance and } \\
\text { symptom validity tests }\end{array}$ \\
\hline Larrabee GJ. & $\begin{array}{l}\text { Introduction: Malingering, research designs, and base rates. In: Larrabee GJ, } \\
\text { editor. Assessment of malingered neuropsychological deficits }\end{array}$ \\
\hline Larrabee GJ. & Performance validity and symptom validity in neuropsychological assessment \\
\hline Lau S. & $\begin{array}{l}\text { Collectivism's individualism: Value preference, personal control, and the } \\
\text { desire for freedom among Chinese in mainland China, Hong Kong, and } \\
\text { Singapore. }\end{array}$ \\
\hline Leite WL, Svinicki M, Shi Y. & $\begin{array}{l}\text { Attempted validation of the scores of the VARK: Learning styles inventory } \\
\text { with multitrait-multimethod confirmatory factor analysis models }\end{array}$ \\
\hline Lewis RF. & Digit Vigilance Test \\
\hline Lewis R, Berghoff P, Pheeney P. & Focusing students: Three approaches for learning through evaluation \\
\hline
\end{tabular}




\begin{tabular}{|c|c|}
\hline Ley K, Young DB. & Instructional principles for self-regulation \\
\hline Ley K, Young DB. & $\begin{array}{l}\text { Self-regulation behaviors in underprepared (developmental) and regular } \\
\text { admission college students }\end{array}$ \\
\hline Ley K, Young DB. & $\begin{array}{l}\text { Self-regulation behaviors in underprepared (developmental) and regular } \\
\text { admission college students }\end{array}$ \\
\hline $\begin{array}{l}\text { Lezak M, Howieson D, Bigler } \\
\text { E, Tranel D. }\end{array}$ & Neuropsychological assessment. 5th. \\
\hline $\begin{array}{l}\text { Long TM, Dauer JT, Kostelnik } \\
\text { KM, Momsen JL, Wyse SA, } \\
\text { Speth EB, Ebert-May D. }\end{array}$ & Fostering ecoliteracy through model-based instruction \\
\hline Loranger AL. & The study strategies of successful and unsuccessful high school students \\
\hline $\begin{array}{l}\text { Lord SM, Prince MJ, Stefanou } \\
\text { CR, Stolk JD, Chen JC. }\end{array}$ & $\begin{array}{l}\text { The effect of different active learning environments on student outcomes } \\
\text { related to lifelong learning }\end{array}$ \\
\hline Hilt LM. & $\begin{array}{l}\text { Attribution Retraining for Therapeutic Change: Theory, Practice, and Future } \\
\text { Directions, Imagination, Cognition and Personality }\end{array}$ \\
\hline $\begin{array}{l}\text { Lounsbury JW, Sundstrom E, } \\
\text { Loveland JM. and Gibson LW. }\end{array}$ & $\begin{array}{l}\text { Intelligence, "Big Five" personality traits, and work drive as predictors of } \\
\text { course grade }\end{array}$ \\
\hline $\begin{array}{l}\text { Lu PH, Boone KB, Cozolino L, } \\
\text { Mitchell C. }\end{array}$ & $\begin{array}{l}\text { Effectiveness of the Rey-Osterrieth Complex Figure Test and the Meyers and } \\
\text { Meyers Recognition Trial in the detection of suspect effort }\end{array}$ \\
\hline Montero L. & La motivación en las personas deficientes mentales, Infancia y Aprendizaje \\
\hline Lujan HL, DiCarlo SE. & First-year medical students prefer multiple learning styles \\
\hline Lundeberg MA, Fox PW. & Do laboratory findings on test expectancy generalize to classroom outcomes? \\
\hline $\begin{array}{l}\text { Luwel K, Torbey J, Verschaffel } \\
\text { L. }\end{array}$ & $\begin{array}{l}\text { The relation between meta-strategy knowledge, strategy use and task } \\
\text { performance: findings and reflections from a numerosity judgment task }\end{array}$ \\
\hline $\begin{array}{l}\text { M. Stiernborg, R. C. } \\
\text { Bandaranayake. }\end{array}$ & Medical students' approaches to studying \\
\hline M.C. Matteucci. & $\begin{array}{l}\text { Attributional retraining and achievement goals: An exploratory study on } \\
\text { theoretical and empirical relationship }\end{array}$ \\
\hline $\begin{array}{l}\text { MacAllister WS, Nakhutina L, } \\
\text { Bender HA, Karantzoulis S, } \\
\text { Carlson C. }\end{array}$ & $\begin{array}{l}\text { Assessing effort during neuropsychological evaluation with the TOMM in } \\
\text { children and adolescents with epilepsy }\end{array}$ \\
\hline Maehr, M. L. and Yamaguchi, R. & Cultural diversity, student motivation and achievement \\
\hline Manly J, Echemendia R. & $\begin{array}{l}\text { Race-specific norms: Using the model of hypertension to understand issues of } \\
\text { race, culture, and education in neuropsychology }\end{array}$ \\
\hline Marc Romainville. & $\begin{array}{l}\text { Awareness of cognitive strategies: The relationship between university } \\
\text { students' metacognition and their performance }\end{array}$ \\
\hline
\end{tabular}




\begin{tabular}{|c|c|}
\hline Marcy V. & $\begin{array}{l}\text { Adult learning styles: How the VARK learning style inventory can be used to } \\
\text { improve student learning }\end{array}$ \\
\hline Margaret Banks, Lisa Woolfson. & $\begin{array}{l}\text { RESEARCH SECTION: Why do students think they fail? The relationship } \\
\text { between attributions and academic self-perceptions }\end{array}$ \\
\hline Markus, H., \& Ruvolo, A. & Possible selves: personalized representations of goals \\
\hline Mars M, Scott RE. & Global e-health policy: a work in progress \\
\hline Martinez, M. & High attrition rates in e-learning: Challenges, predictors, and solutions \\
\hline Marton, F. and Säljö, R. & $\begin{array}{l}\text { On qualitative differences in learning II: Outcome as a function of the } \\
\text { learner's conception of the task }\end{array}$ \\
\hline Marton, F., \& Saljo, R. & Approaches to learning \\
\hline $\begin{array}{l}\text { McCombs, B. L. and Whisler, J. } \\
\text { S. }\end{array}$ & The role of affective variables in autonomous learning \\
\hline $\begin{array}{l}\text { McCrea M, Guskiewicz KM, } \\
\text { Marshall SW, Barr W, Randolph } \\
\text { C, Cantu RC, Onate JA, Yang J, } \\
\text { Kelly JP. }\end{array}$ & $\begin{array}{l}\text { Acute effects and recovery time following concussion in collegiate football } \\
\text { players: The NCAA concussion study }\end{array}$ \\
\hline $\begin{array}{l}\text { McCrea M, Kelly JP, Randolph } \\
\text { C, Cisler R, Berger L. }\end{array}$ & Immediate neurocognitive effects of concussion \\
\hline McHugh M, Joshi M. & Improving evaluations of value-based purchasing programs \\
\hline $\begin{array}{l}\text { McKeachie, W. J., Pintrich, P. R. } \\
\text { and Lin, Y. }\end{array}$ & Teaching learning strategies \\
\hline McKee G. & Why is biological science difficult for first-year nursing students? \\
\hline $\begin{array}{l}\text { McKenzie, K., Gow, K., \& } \\
\text { Schweitzer, R. }\end{array}$ & $\begin{array}{l}\text { Exploring first-year academic achievement through structural equation } \\
\text { modelling }\end{array}$ \\
\hline Mealey, D.L. & Learning and Study Strategies Inventory (LASSI) test review \\
\hline $\begin{array}{l}\text { Meijer, J., Elshout-Mohr, M., } \\
\text { van Daalen-Kapteijns, M., \& } \\
\text { Meeus, W. }\end{array}$ & A self-report inventory for metacognition related to academic tasks \\
\hline $\begin{array}{l}\text { Meijer, J., Elshout-Mohr, M., } \\
\text { van Daalen-Kapteijns, M., } \\
\text { Meeus, W., \& Tempelaar, D. }\end{array}$ & Construction and validation of a questionnaire on metacognition \\
\hline $\begin{array}{l}\text { Meyer AJ, Stomski NJ, Innes SI, } \\
\text { Armson AJ. }\end{array}$ & $\begin{array}{l}\text { VARK learning preferences and mobile anatomy software application use in } \\
\text { pre-clinical chiropractic students }\end{array}$ \\
\hline Meyer, G. & $\begin{array}{l}\text { An experimental study of the old and new types of examination: I. The effects } \\
\text { of examination set on memory }\end{array}$ \\
\hline Meyer, G. & The effects of recall and recognition on the examination set in classroom \\
\hline
\end{tabular}




\begin{tabular}{|c|c|}
\hline & situations \\
\hline Meyers JE, Volbrecht M. & Detection of malingers using the Rey Complex Figure and Recognition Trial \\
\hline $\begin{array}{l}\text { Midgley, C., Kaplan, A., } \\
\text { Middleton, M., Maehr, M., } \\
\text { Urdan, T., Anderman, L., et al. }\end{array}$ & $\begin{array}{l}\text { The development and validation of scales assessing students' achievement } \\
\text { goal orientations }\end{array}$ \\
\hline Miliard M.. & Interoperability also poses big challenges in the UK \\
\hline Minnaert, A. and Janssen, P. & Success and progress in higher education: A structural model of studying \\
\hline $\begin{array}{l}\text { Mittenberg W, Patton C, } \\
\text { Canyock EM, Condit DC. }\end{array}$ & Base rates of malingering and symptom exaggeration \\
\hline $\begin{array}{l}\text { Mittenberg W, Patton C, Legler } \\
\text { W. }\end{array}$ & $\begin{array}{l}\text { Identification of malingered head injury on the Wechsler Memory } \\
\text { Scale-Third Edition }\end{array}$ \\
\hline Moller, A. C., \& Elliot, A. J. & The $2 \times 2$ achievement goal framework: An overview of empirical research \\
\hline Moritz S, Ferahli S, Naber D. & $\begin{array}{l}\text { Memory and attention performance in psychiatric patients: Lack of } \\
\text { correspondence between clinician-rated and patient-rated functioning with } \\
\text { neuropsychological test results }\end{array}$ \\
\hline $\begin{array}{l}\text { Morris, C. D., Bransford, J. D., } \\
\text { \& Franks, J. J. }\end{array}$ & Transfer appropriate processing \\
\hline $\begin{array}{l}\text { Murphy RJ, Gray SA, Straja SR, } \\
\text { Bogert MC. }\end{array}$ & Student learning preferences and teaching implications \\
\hline $\begin{array}{l}\text { NAN (National Academy of } \\
\text { Neuropsychology). }\end{array}$ & $\begin{array}{l}\text { NAN definition of a clinical neuropsychologist: Official position of the } \\
\text { National Academy of Neuropsychology }\end{array}$ \\
\hline $\begin{array}{l}\text { Nathan C. Hall, Raymond P. } \\
\text { Perry, Judith G. Chipperfield, } \\
\text { Rodney A. Clifton, Tara L. } \\
\text { Haynes. }\end{array}$ & $\begin{array}{l}\text { Enhancing Primary and Secondary Control in Achievement Settings Through } \\
\text { Writing-Based Attributional Retraining }\end{array}$ \\
\hline $\begin{array}{l}\text { Nathan C. Hall, Raymond P. } \\
\text { Perry, Thomas Goetz, Joelle C. } \\
\text { Ruthig, Robert H. Stupnisky, } \\
\text { Nancy E. Newall. }\end{array}$ & $\begin{array}{l}\text { Attributional retraining and elaborative learning: Improving academic } \\
\text { development through writing-based interventions }\end{array}$ \\
\hline $\begin{array}{l}\text { Nathan C. Hall, Shannan E. } \\
\text { Jackson Gradt, Thomas Goetz, } \\
\text { Lauren E. Musu-Gillette. }\end{array}$ & $\begin{array}{l}\text { Attributional Retraining, Self-Esteem, and the Job Interview: Benefits and } \\
\text { Risks for College Student Employment }\end{array}$ \\
\hline $\begin{array}{l}\text { Nathan C. Hall, Steven Hladkyj, } \\
\text { Raymond P. Perry, Joelle C. } \\
\text { Ruthig. }\end{array}$ & $\begin{array}{l}\text { The Role of Attributional Retraining and Elaborative Learning in College } \\
\text { Students' Academic Development }\end{array}$ \\
\hline Niccolls R, Bolter JF. & Multi-Digit Memory Test \\
\hline Nicol DJ, Macfarlane-Dick D. & $\begin{array}{l}\text { Formative assessment and self-regulated learning: a model and seven } \\
\text { principles of good feedback practice }\end{array}$ \\
\hline
\end{tabular}




\begin{tabular}{|c|c|}
\hline $\begin{array}{l}\text { Nicolina M. Fazio, Linda J. } \\
\text { Palm. }\end{array}$ & $\begin{array}{l}\text { Attributional Style, Depression, and Grade Point Averages of College } \\
\text { Students }\end{array}$ \\
\hline $\begin{array}{l}\text { NIH (National Institutes of } \\
\text { Health). }\end{array}$ & NIH toolbox: Processing speed \\
\hline Nungester R, Duchastel P. & Testing versus review: effects on retention \\
\hline $\begin{array}{l}\text { Nuzhat A, Salem RO, Quadri } \\
\text { MS, Al-Hamdan N. }\end{array}$ & $\begin{array}{l}\text { Learning style preferences of medical students: A single-institute experience } \\
\text { from Saudi Arabia }\end{array}$ \\
\hline $\begin{array}{l}\text { OIDAP (Occupational } \\
\text { Information Development } \\
\text { Advisory Panel). }\end{array}$ & $\begin{array}{l}\text { Mental cognitive subcommittee: Content model and classification } \\
\text { recommendations }\end{array}$ \\
\hline Olausen, B. S., \& Bräten, I. & $\begin{array}{l}\text { Students' use of strategies for self-regulated learning: cross-cultural } \\
\text { perspectives }\end{array}$ \\
\hline Oyserman, D., \& Markus, H. & Possible selves and delinquency \\
\hline Palmer, D. and Goetz, E. T. & $\begin{array}{l}\text { Selection and the use of study strategies: The role of the studier's beliefs about } \\
\text { self and strategies }\end{array}$ \\
\hline $\begin{array}{l}\text { Papanagnou D, Serrano A, } \\
\text { Barkley K, Chandra S, } \\
\text { Governatori N, Piela N, Wanner } \\
\text { GK, Shin R. }\end{array}$ & $\begin{array}{l}\text { Does tailoring instructional style to a medical student's self-perceived } \\
\text { learning style improve performance when teaching intravenous catheter } \\
\text { placement? A randomized controlled study }\end{array}$ \\
\hline Paris SG, Newman RS. & Development aspects of self-regulated learning \\
\hline $\begin{array}{l}\text { Pashler H, McDaniel M, Rohrer } \\
\text { D, Bjork R. }\end{array}$ & Learning styles: Concepts and evidence \\
\hline $\begin{array}{l}\text { Patti C. Parker, Raymond P. } \\
\text { Perry, Jeremy M. Hamm, Judith } \\
\text { G. Chipperfield, Steve Hladkyj. }\end{array}$ & $\begin{array}{l}\text { Enhancing the academic success of competitive student athletes using a } \\
\text { motivation treatment intervention (Attributional Retraining) }\end{array}$ \\
\hline Paulhus DL. & Paulhus Deception Scales (PDS) \\
\hline Perels F, Gürtler T, Schmitz B. & Training of self-regulatory and problem-solving competence \\
\hline Perkins DN. & What constructivism demands of the learner \\
\hline $\begin{array}{l}\text { Perry RP, Hladkyj S, Pekrun } \\
\text { RH, Clifton RA, Chipperfield } \\
\text { JG. }\end{array}$ & $\begin{array}{l}\text { Perceived academic control and failure in college students: a three-year study } \\
\text { of scholastic attainment }\end{array}$ \\
\hline $\begin{array}{l}\text { Peyman H, Sadeghifar J, } \\
\text { Khajavikhan J, Yasemi M, } \\
\text { Rasool M, Yaghoubi YM, Nahal } \\
\text { MM, Karim H. }\end{array}$ & $\begin{array}{l}\text { Using VARK approach for assessing preferred learning styles of first year } \\
\text { medical sciences students: A survey from Iran }\end{array}$ \\
\hline Phipps, R. and Merisotis, J. & What's the difference? A review of contemporary research on the \\
\hline
\end{tabular}




\begin{tabular}{|c|c|}
\hline & effectiveness of distance learning in higher education \\
\hline Pintrich PR, De Groot EV. & $\begin{array}{l}\text { Motivational and self-regulated learning components of classroom academic } \\
\text { performance }\end{array}$ \\
\hline $\begin{array}{l}\text { Pintrich PR, Smith DAF, Garcia } \\
\text { T, McKeachie WJ. }\end{array}$ & $\begin{array}{l}\text { A Manual for the Use of the Motivated Strategies for Learning Questionnaire } \\
\text { (MSLQ) }\end{array}$ \\
\hline Pintrich, P. R. & The role of goal orientation in self-regulated learning \\
\hline Pintrich, P. R. & $\begin{array}{l}\text { A conceptual framework for assessing motivation and self-regulated learning } \\
\text { in college students }\end{array}$ \\
\hline Pintrich, P. R., \& DeGroot, E. V. & $\begin{array}{l}\text { Motivational and self-regulated learning components of classroom academic } \\
\text { performance }\end{array}$ \\
\hline Pintrich, P. R., \& Garcia, T. & Student goal orientation and self-regulation in the classroom \\
\hline $\begin{array}{l}\text { Poortvliet, P. M., Janssen, O., } \\
\text { Van Yperen, N. W., \& Van de } \\
\text { Vliert, E. }\end{array}$ & $\begin{array}{l}\text { Achievement Goals and interpersonal behavior: How mastery and } \\
\text { performance goals shape information exchange }\end{array}$ \\
\hline Popovich NG. & Educational care of pharmacy \\
\hline Porter ME. & A strategy for health care reform — toward a value-based system \\
\hline Porter ME. & What is value in health care? \\
\hline Pressley, M. & $\begin{array}{l}\text { More about the development of self-regulation: complex, long-term and } \\
\text { thoroughly social }\end{array}$ \\
\hline Prithishkumar IJ, Michael SA. & Understanding your student: Using the VARK model \\
\hline $\begin{array}{l}\text { Qureshi, E., Morton, L. L. and } \\
\text { Antosz, E. }\end{array}$ & $\begin{array}{l}\text { An interesting profile - University students who take distance education } \\
\text { courses show weaker motivation than on-campus students }\end{array}$ \\
\hline R Development Core Team. & R: A Language and Environment for Statistical Computing \\
\hline Randolph C. & $\begin{array}{l}\text { Repeatable Battery for the Assessment of Neuropsychological Status } \\
\text { (RBANS) }\end{array}$ \\
\hline Rao SM. & Neuropsychology of multiple sclerosis: A critical review \\
\hline $\begin{array}{l}\text { Raudenbush, S. W., \& Bryk, A. } \\
\text { S. }\end{array}$ & Hierarchical linear models: Applications and data analysis methods \\
\hline $\begin{array}{l}\text { Raymond P. Perry, Dieter J. } \\
\text { Schonwetter, Jamie-Lynn } \\
\text { Magnusson, C. Ward Struthers. }\end{array}$ & $\begin{array}{l}\text { Students' explanatory schemas and the quality of college instruction: Some } \\
\text { evidence for buffer and compensation effects }\end{array}$ \\
\hline $\begin{array}{l}\text { Raymond P. Perry, Frank J. } \\
\text { Hechter, Verena H. Menec, Leah } \\
\text { E. Weinberg. }\end{array}$ & $\begin{array}{l}\text { Enhancing achievement motivation and performance in college students: An } \\
\text { attributional retraining perspective }\end{array}$ \\
\hline Raymond P. Perry, Judith G. & Attribution-Based Treatment Interventions in Some Achievement Settings \\
\hline
\end{tabular}




\begin{tabular}{|c|c|}
\hline $\begin{array}{l}\text { Chipperfield, Steve Hladkyj, } \\
\text { Reinhard Pekrun, Jeremy M. } \\
\text { Hamm. }\end{array}$ & \\
\hline $\begin{array}{l}\text { Raymond P. Perry, Nathan C. } \\
\text { Hall, Joelle C. Ruthig. }\end{array}$ & Perceived (Academic) Control and Scholastic Attainment in Higher Education \\
\hline $\begin{array}{l}\text { Raymond P. Perry, Robert H. } \\
\text { Stupnisky, Nathan C. Hall, } \\
\text { Judith G. Chipperfield, Bernard } \\
\text { Weiner. }\end{array}$ & $\begin{array}{l}\text { Bad Starts and Better Finishes: Attributional Retraining and Initial } \\
\text { Performance in Competitive Achievement Settings }\end{array}$ \\
\hline $\begin{array}{l}\text { Rebecca Maymon, Nathan C. } \\
\text { Hall, Thomas Goetz, Andrew } \\
\text { Chiarella, Sonia Rahimi. }\end{array}$ & $\begin{array}{l}\text { Technology, attributions, and emotions in post-secondary education: An } \\
\text { application of Weiner's attribution theory to academic computing problems }\end{array}$ \\
\hline Reinagel A, Bray Speth E. & $\begin{array}{l}\text { Beyond the central dogma: model-based learning of how genes determine } \\
\text { phenotypes }\end{array}$ \\
\hline Reiner C, Willingham D. & The myth of learning styles \\
\hline Reitan RM, Wolfson D. & $\begin{array}{l}\text { The Halstead-Reitan neuropsychological test battery: Theory and clinical } \\
\text { interpretation — second edition }\end{array}$ \\
\hline Reitan RM. & Trail Making Test: Manual for administration and scoring \\
\hline $\begin{array}{l}\text { Reveni R. Moodaley, Adelene } \\
\text { A. Grobler, Willy Lens. }\end{array}$ & Study Orientation and Causal Attribution in Mathematics Achievement \\
\hline Rey A. & $\begin{array}{l}\text { L'examen psychologique dans les cas d'encéphalopathie traumatique (les } \\
\text { problems) }\end{array}$ \\
\hline Rey A. & The clinical examination in psychology \\
\hline $\begin{array}{l}\text { Richardson M, Abraham C, } \\
\text { Bond R. }\end{array}$ & $\begin{array}{l}\text { Psychological correlates of university students' academic performance: a } \\
\text { systematic review and meta-analysis }\end{array}$ \\
\hline $\begin{array}{l}\text { Ridgell, S. D. and Lounsbury, J. } \\
\text { W. }\end{array}$ & $\begin{array}{l}\text { Predicting academic success: General intelligence, "Big Five" personality } \\
\text { traits, and work drive }\end{array}$ \\
\hline $\begin{array}{l}\text { Roberson CJ, Boone KB, } \\
\text { Goldberg H, Miora D, } \\
\text { Cottingham M, Victor T, Ziegler } \\
\text { E, Zeller M, Wright M. }\end{array}$ & Cross validation of the B test in a large known groups sample \\
\hline $\begin{array}{l}\text { Rodney A. Clifton, Jeremy M. } \\
\text { Hamm, Patti C. Parker. }\end{array}$ & Promoting Effective Teaching and Learning in Higher Education \\
\hline Roediger H, Karpicke J. & $\begin{array}{l}\text { The power of testing memory: basic research and implications for educational } \\
\text { practice }\end{array}$ \\
\hline $\begin{array}{l}\text { Roghayeh Gandomkar, Azim } \\
\text { Mirzazadeh, Mohammad Jalili, } \\
\text { Kamran Yazdani, Ladan Fata, } \\
\text { John Sandars. }\end{array}$ & $\begin{array}{l}\text { Self-regulated learning processes of medical students during an academic } \\
\text { learning task }\end{array}$ \\
\hline
\end{tabular}




\begin{tabular}{|c|c|}
\hline Ruben RJ. & $\begin{array}{l}\text { Redefining the survival of the fittest: Communication disorders in the } 21 \text { st } \\
\text { century }\end{array}$ \\
\hline S. M. Chedzoy, R. L. Burden. & Marking Time or Moving on, Research in Education \\
\hline S., \& Renninger, K. A. & The four-phase model of interest development \\
\hline $\begin{array}{l}\text { Salazar XF, Lu PH, Wen J, } \\
\text { Boone KB. }\end{array}$ & $\begin{array}{l}\text { The use of effort tests in ethnic minorities and in non-English-speaking and } \\
\text { English as a second language populations }\end{array}$ \\
\hline Salekin KL, Doane BM. & $\begin{array}{l}\text { Malingering intellectual disability: The value of available measures and } \\
\text { methods }\end{array}$ \\
\hline Salili, F. & Explaining Chinese motivation and achievement \\
\hline Salili, F. & $\begin{array}{l}\text { Achievement motivation: A cross-cultural comparison of British and Chinese } \\
\text { students }\end{array}$ \\
\hline $\begin{array}{l}\text { Salili, F., Chiu, C. Y. and Hong, } \\
\text { Y. Y. }\end{array}$ & Student motivation: The culture and context of learning \\
\hline Salili, F., Chiu, C. Y. and Lai, S. & $\begin{array}{l}\text { The influence of culture and context on students' motivational orientation and } \\
\text { performance }\end{array}$ \\
\hline $\begin{array}{l}\text { Samarakoon L, Fernando T, } \\
\text { Rodrigo C, Rajapakse S. }\end{array}$ & $\begin{array}{l}\text { Learning styles and approaches to learning among medical undergraduate and } \\
\text { postgraduates }\end{array}$ \\
\hline Sax, G., \& Collet, L. S.. & $\begin{array}{l}\text { An empirical comparison of the effects of recall and multiple choice tests on } \\
\text { student achievement }\end{array}$ \\
\hline Schacter DL. & $\begin{array}{l}\text { Toward a cognitive neuropsychology of awareness: Implicit knowledge and } \\
\text { anosognosia }\end{array}$ \\
\hline $\begin{array}{l}\text { Schellings G, Van Hout-Wolters } \\
\text { B. }\end{array}$ & $\begin{array}{l}\text { Measuring strategy use with self-report instruments: theoretical and empirical } \\
\text { considerations }\end{array}$ \\
\hline Schmidt M. & Auditory Verbal Learning Test: RAVLT: A handbook \\
\hline Schmidt, A. M., \& Ford, K. J. & $\begin{array}{l}\text { Learning with a learner control-training environment: the interactive effects of } \\
\text { goals orientation and metacognitive instruction on learning outcomes }\end{array}$ \\
\hline $\begin{array}{l}\text { Schraw G, Crippen KJ, Hartley } \\
\text { K. }\end{array}$ & $\begin{array}{l}\text { Promoting self-regulation in science education: metacognition as part of a } \\
\text { broader perspective on learning }\end{array}$ \\
\hline Schraw G, Moshman D. & Metacognitive theories \\
\hline Schraw, G., \& Dennison, R. S. & Assessing metacognitive awareness \\
\hline $\begin{array}{l}\text { Schraw, G., Horn, C., } \\
\text { Thorndike-Christ, T., \& } \\
\text { Bruning, R. }\end{array}$ & Academic goal orientations and student classroom achievement \\
\hline $\begin{array}{l}\text { Schretlen DJ, Testa S, Winicki } \\
\text { JM, Pearlson GD, Gordon B. }\end{array}$ & $\begin{array}{l}\text { Frequency and bases of abnormal performance by healthy adults on } \\
\text { neuropsychological testing }\end{array}$ \\
\hline
\end{tabular}




\begin{tabular}{|c|c|}
\hline Schunk, D. H. & Social cognitive theory and self-regulated learning \\
\hline Schunk, D. H. & Social cognitive theory and self-regulated learning \\
\hline Scott C. & The enduring appeal of 'learning styles' \\
\hline Scouller K. & $\begin{array}{l}\text { The influence of assessment method on students' learning approaches: } \\
\text { multiple choice question examination versus assignment essay }\end{array}$ \\
\hline Seery MK. & $\begin{array}{l}\text { Flipped learning in higher education chemistry: emerging trends and potential } \\
\text { directions }\end{array}$ \\
\hline Semel E, Wiig E, Secord W. & Clinical evaluation of language fundamentals: Examiners manual. 4th \\
\hline $\begin{array}{l}\text { Senko, C., Hulleman, C. S., \& } \\
\text { Harackiewicz, J. M. }\end{array}$ & $\begin{array}{l}\text { Achievement goal theory at the crossroads: Old controversies, current } \\
\text { challenges, and new directions }\end{array}$ \\
\hline Seymour E, Hewitt NM. & Talking about Leaving: Why Undergraduates Leave the Sciences \\
\hline $\begin{array}{l}\text { Shandera AL, Berry DT, Clark } \\
\text { JA, Schipper LJ, Graue LO, } \\
\text { Harp JP. }\end{array}$ & Detection of malingered mental retardation \\
\hline Shell, D. F., \& Husman, J. & $\begin{array}{l}\text { Control, motivation, and strategic self-regulation in the college classroom: A } \\
\text { multidimensional phenomenon }\end{array}$ \\
\hline Sheslow D, Adams W. & $\begin{array}{l}\text { Wide range assessment of memory and learning second edition administration } \\
\text { and technical manual }\end{array}$ \\
\hline Sikka R, Morath JM, Leape L. & The quadruple aim: care, health, cost and meaning in work \\
\hline Silverberg ND, Millis SR. & $\begin{array}{l}\text { Impairment versus deficiency in neuropsychological assessment: Implications } \\
\text { for ecological validity }\end{array}$ \\
\hline Sitzmann T, Ely K. & $\begin{array}{l}\text { A meta-analysis of self-regulated learning in work-related training and } \\
\text { educational attainment: what we know and where we need to go }\end{array}$ \\
\hline $\begin{array}{l}\text { Slater JA, Lujan HL, DiCarlo } \\
\text { SE. }\end{array}$ & $\begin{array}{l}\text { Does gender influence learning style preferences of first-year medical } \\
\text { students? }\end{array}$ \\
\hline $\begin{array}{l}\text { Slick DJ, Hopp G, Strauss E, } \\
\text { Thompson GB. }\end{array}$ & Victoria Symptom Validity Test: Professional manual \\
\hline $\begin{array}{l}\text { Slick DJ, Sherman EMS, } \\
\text { Iverson GL. }\end{array}$ & $\begin{array}{l}\text { Diagnostic criteria for malingered neurocognitive dysfunction: Proposed } \\
\text { standards for clinical practice and research }\end{array}$ \\
\hline $\begin{array}{l}\text { Smith L, Krass I, Sainsbury E, } \\
\text { Rose G. }\end{array}$ & $\begin{array}{l}\text { Pharmacy students' approaches to learning in undergraduate and graduate } \\
\text { entry programs }\end{array}$ \\
\hline Sollman MJ, Berry DT. & $\begin{array}{l}\text { Detection of inadequate effort on neuropsychological testing: A meta-analytic } \\
\text { update and extension }\end{array}$ \\
\hline $\begin{array}{l}\text { Solomon RE, Boone KB, Miora } \\
\text { D, Skidmore S, Cottingham M, } \\
\text { Victor T, Ziegler E, Zeller M. }\end{array}$ & $\begin{array}{l}\text { Use of the WAIS-III picture completion subtest as an embedded measure of } \\
\text { response bias }\end{array}$ \\
\hline
\end{tabular}




\begin{tabular}{|c|c|}
\hline Somuncuoglu, J., \& Yildirim, A. & $\begin{array}{l}\text { Relationship between achievement goal orientations and use of learning } \\
\text { strategies }\end{array}$ \\
\hline $\begin{array}{l}\text { Sperling, R. A., Howard, B. C., } \\
\text { Staley, R., \& DuBois, N. }\end{array}$ & Metacognition and self-regulated learning constructs \\
\hline Spreen O, Strauss E. & Controlled oral word association (word fluency) \\
\hline $\begin{array}{l}\text { SSA (Social Security } \\
\text { Administration). }\end{array}$ & $\begin{array}{l}\text { Disability evaluation under social security_-Part III: Listing of } \\
\text { impairments_-Adult listings (Part A)—section } 12.00 \text { mental disorders }\end{array}$ \\
\hline SSA. & Disability evaluation under Social Security: Part I—general information \\
\hline $\begin{array}{l}\text { Stanton JD, Neider XN, } \\
\text { Gallegos IJ, Clark NC. }\end{array}$ & $\begin{array}{l}\text { Differences in metacognitive regulation in introductory biology students: } \\
\text { when prompts are not enough }\end{array}$ \\
\hline Steiner H. & $\begin{array}{l}\text { The strategy project: promoting self-regulated learning through an authentic } \\
\text { assignment }\end{array}$ \\
\hline $\begin{array}{l}\text { Steinmayr, R., Bipp, T., \& } \\
\text { Spinath, B. }\end{array}$ & $\begin{array}{l}\text { Goal orientations predict academic perfor-mance beyond intelligence and } \\
\text { personality }\end{array}$ \\
\hline $\begin{array}{l}\text { Stevens A, Schneider K, Liske } \\
\text { B, Hermle L, Huber H, Hetzel } \\
\text { G. }\end{array}$ & $\begin{array}{l}\text { Is subnormal cognitive performance in schizophrenia due to lack of effort or } \\
\text { to cognitive impairment? }\end{array}$ \\
\hline $\begin{array}{l}\text { Strauss E, Sherman EM, Spreen } \\
\text { O. }\end{array}$ & $\begin{array}{l}\text { A compendium of neuropsychological tests: Administration, norms, and } \\
\text { commentary }\end{array}$ \\
\hline $\begin{array}{l}\text { Suárez Reveiro, J. M., Gonzales } \\
\text { Cabanach, R., \& Valle Arias, A. }\end{array}$ & $\begin{array}{l}\text { Multiple-goal pursuit and its relation to cognitive, self-regulatory, and } \\
\text { motivational strategies }\end{array}$ \\
\hline Suber, J. R. & $\begin{array}{l}\text { The effect of test expectation, subject matter, and passage length on study } \\
\text { tactics and retention }\end{array}$ \\
\hline $\begin{array}{l}\text { Suchy Y, Chelune G, Franchow } \\
\text { EI, Thorgusen SR. }\end{array}$ & $\begin{array}{l}\text { Confronting patients about insufficient effort: The impact on subsequent } \\
\text { symptom validity and memory performance }\end{array}$ \\
\hline Sue, S. and Okazaki, S. & $\begin{array}{l}\text { Asian American educational achievement: A phenomenon in search of an } \\
\text { explanation }\end{array}$ \\
\hline Suhr JA, Boyer D. & $\begin{array}{l}\text { Use of the Wisconsin Card Sorting Test in the detection of malingering in } \\
\text { student simulator and patient samples }\end{array}$ \\
\hline Susan Loyola. & Evidence-Based Teaching Guidelines \\
\hline $\begin{array}{l}\text { Sweet JJ, Meyer DG, Nelson } \\
\text { NW, Moberg PJ. }\end{array}$ & $\begin{array}{l}\text { The TCN/AACN } 2010 \text { "salary survey": Professional practices, beliefs, and } \\
\text { incomes of U.S. neuropsychologists }\end{array}$ \\
\hline Tanner K, Allen D. & $\begin{array}{l}\text { Approaches to biology teaching and learning: Learning styles and the problem } \\
\text { of instructional selection - Engaging all students in science courses }\end{array}$ \\
\hline Tanner KD. & Promoting student metacognition \\
\hline Tara L. Haynes Stewart, Rodney & Attributional Retraining: reducing the likelihood of failure \\
\hline
\end{tabular}




\begin{tabular}{|c|c|}
\hline $\begin{array}{l}\text { A. Clifton, Lia M. Daniels, } \\
\text { Raymond P. Perry, Judith G. } \\
\text { Chipperfield, Joelle C. Ruthig. }\end{array}$ & \\
\hline $\begin{array}{l}\text { Tara L. Haynes, Joelle C. } \\
\text { Ruthig, Raymond P. Perry, } \\
\text { Robert H. Stupnisky, Nathan C. } \\
\text { Hall. }\end{array}$ & $\begin{array}{l}\text { Reducing the Academic Risks of Over-Optimism: The Longitudinal Effects of } \\
\text { Attributional Retraining on Cognition and Achievement }\end{array}$ \\
\hline $\begin{array}{l}\text { Tara L. Haynes, Lia M. Daniels, } \\
\text { Robert H. Stupnisky, Raymond } \\
\text { P. Perry, Steve Hladkyj. }\end{array}$ & $\begin{array}{l}\text { The Effect of Attributional Retraining on Mastery and Performance } \\
\text { Motivation Among First-Year College Students }\end{array}$ \\
\hline $\begin{array}{l}\text { Tara L. Haynes, Raymond P. } \\
\text { Perry, Robert H. Stupnisky, Lia } \\
\text { M. Daniels. }\end{array}$ & $\begin{array}{l}\text { A Review of Attributional Retraining Treatments: Fostering Engagement and } \\
\text { Persistence in Vulnerable College Students }\end{array}$ \\
\hline Ted Thompson. & Self-worth Protection: review and implications for the classroom \\
\hline $\begin{array}{l}\text { Teena Willoughby, Taylor } \\
\text { Heffer, Victoria W. Dykstra, } \\
\text { Hamnah Shahid, Joelle Braccio. }\end{array}$ & $\begin{array}{l}\text { A Latent Class Analysis of Adolescents in First-Year University: Associations } \\
\text { with Psychosocial Adjustment Throughout the Emerging Adult Period and } \\
\text { Post-University Outcomes }\end{array}$ \\
\hline $\begin{array}{l}\text { The Comptroller and Auditor } \\
\text { General of the National Audit } \\
\text { Office (UK). }\end{array}$ & Investigation: WannaCry cyber-attack and the NHS. UK Department of Health \\
\hline Thomas DR. & A general inductive approach for analyzing qualitative evaluation data \\
\hline Thomas Goetz, Madeleine Bieg. & Academic Emotions and Their Regulation via Emotional Intelligence \\
\hline $\begin{array}{l}\text { Tiaden, C., Grieder, S., \& } \\
\text { Steiner, G. }\end{array}$ & Metacognition and its relatedness to self-regulated learning \\
\hline $\begin{array}{l}\text { Timothy D. Wilson, Michelle } \\
\text { Damiani, Nicole Shelton. }\end{array}$ & $\begin{array}{l}\text { Improving the Academic Performance of College Students with Brief } \\
\text { Attributional Interventions }\end{array}$ \\
\hline Tombaugh TN, Tombaugh PW. & Test of Memory Malingering: TOMM \\
\hline Trahan DE, Larrabee GJ. & Continuous Visual Memory Test \\
\hline Tulving, E. & Elements of episodic memory \\
\hline $\begin{array}{l}\text { Urval RP, Kamath A, Ullal S, } \\
\text { Shenoy AK, Shenoy N, Udupa } \\
\text { L. }\end{array}$ & $\begin{array}{l}\text { Assessment of learning styles of undergraduate medical students using the } \\
\text { VARK questionnaire and the influence of sex and academic performance }\end{array}$ \\
\hline $\begin{array}{l}\text { van Gorp WG, Humphrey LA, } \\
\text { Kalechstein A, Brumm VL, } \\
\text { McMullen WJ, Stoddard M, } \\
\text { Pachana NA. }\end{array}$ & $\begin{array}{l}\text { How well do standard clinical neuropsychological tests identify malingering?: } \\
\text { A preliminary analysis }\end{array}$ \\
\hline $\begin{array}{l}\text { Van Zile-Tamsen, C., \& } \\
\text { Livingston, J. A. }\end{array}$ & $\begin{array}{l}\text { The differential impact of motivation on the self regulated strategy use of } \\
\text { high- and low-achieving college students }\end{array}$ \\
\hline
\end{tabular}




\begin{tabular}{|c|c|}
\hline $\begin{array}{l}\text { Vandevelde S, Van Keer H, } \\
\text { Rosseel Y. }\end{array}$ & $\begin{array}{l}\text { Measuring the complexity of upper primary school children's self-regulated } \\
\text { learning: a multi-component approach }\end{array}$ \\
\hline $\begin{array}{l}\text { Vansteenkiste, M., Mouratidis, } \\
\text { A., \& Lens, W. }\end{array}$ & $\begin{array}{l}\text { Detaching reasons from aims: Fairplay and well-being in soccer as a function } \\
\text { of pursuing performance-approach goals for autonomous or controlling } \\
\text { reasons }\end{array}$ \\
\hline VARK. & $\begin{array}{l}\text { The VARK questionnaire: How do I learn best? VARK questionnaire version } \\
\text { 7.1. }\end{array}$ \\
\hline $\begin{array}{l}\text { Veenman MV, Van Hout-Wolters } \\
\text { BH, Afflerbach P. }\end{array}$ & Metacognition and learning: conceptual and methodological considerations \\
\hline Veenman MVJ. & $\begin{array}{l}\text { Alternative assessment of strategy use with self-report instruments: a } \\
\text { discussion }\end{array}$ \\
\hline $\begin{array}{l}\text { Veenman, M. V. J., \& } \\
\text { Beishuizen, J. J. }\end{array}$ & $\begin{array}{l}\text { Intellectual and metacognitive skills of novices while studying texts under } \\
\text { conditions of text difficulty and time constraint }\end{array}$ \\
\hline Veenman, M. V. J., \& Verheij, J. & $\begin{array}{l}\text { Technical students' metacognitive skills: relating general vs. specific } \\
\text { metacognitive skills to study success }\end{array}$ \\
\hline $\begin{array}{l}\text { Veenman, M. V. J., Van } \\
\text { Hout-Wolters, B. H. A. M., \& } \\
\text { Afflerbach, P. }\end{array}$ & Metacognition and learning: conceptual and methodological considerations \\
\hline $\begin{array}{l}\text { Verena H. Menec, Raymond P. } \\
\text { Perry, C. Ward Struthers, Dieter } \\
\text { J. Schonwetter, Frank J. Hechter, } \\
\text { Brila L. Eichholz. }\end{array}$ & $\begin{array}{l}\text { Assisting At-Risk College Students With Attributional Retraining and } \\
\text { Effective Teaching }\end{array}$ \\
\hline $\begin{array}{l}\text { Verena H. Menec, Raymond P. } \\
\text { Perry. }\end{array}$ & $\begin{array}{l}\text { Disciplinary differences in students' perceptions of success: Modifying } \\
\text { misperceptions with attributional retraining }\end{array}$ \\
\hline $\begin{array}{l}\text { Vermetten, Y. J., Lodewijks, H. } \\
\text { G., \& Vermunt, J. D. }\end{array}$ & The role of personality traits and goal orientations in strategy use \\
\hline $\begin{array}{l}\text { Victor TL, Boone K, Serpa JG, } \\
\text { Buehler J, Ziegler E. }\end{array}$ & Interpreting the meaning of multiple symptom validity test failure \\
\hline Victor TL, Boone KB. & Identification of feigned mental retardation \\
\hline Warrington E. & Recognition Memory Test manual \\
\hline $\begin{array}{l}\text { Wäschle K, Allgaier A, Lachner } \\
\text { A, Fink S, Nückles M. }\end{array}$ & $\begin{array}{l}\text { Procrastination and self-efficacy: tracing vicious and virtuous circles in } \\
\text { self-regulated learning }\end{array}$ \\
\hline Wechsler D. & $\begin{array}{l}\text { Wechsler Adult Intelligence Scale (WAIS-III): Administration and scoring } \\
\text { manual—3rd edition }\end{array}$ \\
\hline Wechsler D. & Wechsler Intelligence Scale for Children — fourth edition (WISC-IV) \\
\hline Wechsler D. & WMS-III: Wechsler Memory Scale administration and scoring manual \\
\hline Wehrwein EA, Lujan HL, & Gender differences in learning style preferences among undergraduate \\
\hline
\end{tabular}




\begin{tabular}{|c|c|}
\hline DiCarlo SE. & physiology students \\
\hline Weiner, B. & An attributional theory of achievement motivation and emotion \\
\hline $\begin{array}{l}\text { Weinstein C, Schulte A, Palmer } \\
\text { D. }\end{array}$ & LASSI: Learning and Study Strategies Inventory \\
\hline Weinstein, C. E. & Assessment and training of student learning strategies \\
\hline $\begin{array}{l}\text { Weinstein, C. E. and Mayer, R. } \\
\text { E. }\end{array}$ & The teaching of learning strategies \\
\hline $\begin{array}{l}\text { Weinstein, C. E., Zimmermann, } \\
\text { S. A., Palmer, D. R. }\end{array}$ & Assessing learning strategies: the design and development of the LASSI \\
\hline Wheeler MA, Roediger HL. & $\begin{array}{l}\text { Disparate effects of repeated testing: Reconciling Ballard's (1913) and } \\
\text { Bartlett's (1932) results }\end{array}$ \\
\hline $\begin{array}{l}\text { WHO (World Health } \\
\text { Organization). }\end{array}$ & International classification of functioning, disability, and health (ICF) \\
\hline Wingate U. & A framework for transition: supporting "learning to learn" in higher education \\
\hline Winne, P. H. & Inherent details in self-regulated learning \\
\hline Winne, P. H. & A metacognitive view of individual differences in self-regulated learning \\
\hline Winne, P. H. & Self-regulated learning viewed from models of information processing \\
\hline Winne, P. H. & A perspective on state-of-the-art research on self-regulated learning \\
\hline Winne, P. H. & Improving measurements of self-regulated learning \\
\hline Winne, P. H., \& Hadwin, A. F. & Studying as self-regulated learning \\
\hline Wolters CA. & $\begin{array}{l}\text { Regulation of motivation: evaluating an underemphasized aspect of } \\
\text { self-regulated learning }\end{array}$ \\
\hline Wolters, C. A. & Self-regulated learning and college students' regulation of motivation \\
\hline Wolters, C. A. & Understanding procrastination from a self-regulated learning perspective \\
\hline Wolters, C. A. & $\begin{array}{l}\text { Advancing achievement goal theory: using goals structures and goal } \\
\text { orientations to predict students' motivation, cognition and achievement }\end{array}$ \\
\hline Woolfolk A. & Educational Psychology \\
\hline World Economic Forum. & Value in healthcare: laying the foundation for health system transformation \\
\hline Yates F. & Contingency table involving small numbers and the $\chi^{2}$ test \\
\hline Young G. & $\begin{array}{l}\text { Resource material for ethical psychological assessment of symptom and } \\
\text { performance validity, including malingering }\end{array}$ \\
\hline
\end{tabular}




\begin{tabular}{|l|l|}
\hline Zhang, L. F. & $\begin{array}{l}\text { Abilities, academic performance, learning approaches, and thinking styles: A } \\
\text { three-culture investigation }\end{array}$ \\
\hline $\begin{array}{l}\text { Zimmerman BJ, Martinez-Pons } \\
\text { M. }\end{array}$ & Construct validation of a strategy model of student self-regulated learning \\
\hline $\begin{array}{l}\text { Zimmerman BJ, Martinez-Pons } \\
\text { M. }\end{array}$ & $\begin{array}{l}\text { Development of a structured interview for assessing student use of } \\
\text { self-regulated learning strategies }\end{array}$ \\
\hline Zimmerman BJ. & $\begin{array}{l}\text { Investigating self-regulation and motivation: historical background, } \\
\text { methodological developments, and future prospects }\end{array}$ \\
\hline Zimmerman BJ. & Self-regulated learning and academic achievement: an overview \\
\hline Zimmerman, B. J. & Becoming a self-regulated learner: Which are the key subprocesses? \\
\hline Zimmerman, B. J. & A social cognitive view of self-regulated academic learning \\
\hline Zimmerman, B. J. & $\begin{array}{l}\text { Developing self-fulfilling cycles of academic regulation: An analysis of } \\
\text { exemplary instructional models }\end{array}$ \\
\hline Zimmerman, B. J. & Attaining self-regulation: A social cognitive perspective \\
\hline $\begin{array}{l}\text { Zimmerman, B. J., \& Kitsantas, } \\
\text { A. }\end{array}$ & $\begin{array}{l}\text { The hidden dimension of personal competence: self-regulated learning and } \\
\text { practice }\end{array}$ \\
\hline $\begin{array}{l}\text { Zimmerman, B. J., \& } \\
\text { Martinez-Pons, M. }\end{array}$ & Construct validation of a strategy model of student self regulated learning \\
\hline $\begin{array}{l}\text { Zimmerman, B. J., \& } \\
\text { Martinez-Pons, M. }\end{array}$ & $\begin{array}{l}\text { Student differences in self-regulated learning: Relating grade, sex, and } \\
\text { giftedness to self-efficacy and strategy use }\end{array}$ \\
\hline $\begin{array}{l}\text { Zimmerman, B. J., \& Schunk, } \\
\text { D. H. }\end{array}$ & Self-regulated learning and academic achievement: theoretical perspectives \\
\hline \&immerman, B. J., Bandura, A., & $\begin{array}{l}\text { Self-motivation for academic attainment: The role of self-efficacy beliefs and } \\
\text { personal goal setting. }\end{array}$ \\
\hline
\end{tabular}

Excluded articles from manual search full-text screen

\begin{tabular}{|l|l|}
\hline Authors & $\underline{\text { Title }}$ \\
\hline $\begin{array}{l}\text { Ferla, J., Valcke, M., Schuyten, } \\
\text { G }\end{array}$ & Student models of learning and their impact on study strategies \\
\hline Bhutkar MV, Bhutkar PM & $\begin{array}{l}\text { Effect of awareness of learning styles and modifications in study modalities } \\
\text { on academic performance in first MBBS students }\end{array}$ \\
\hline $\begin{array}{l}\text { Broekkamp H, Van } \\
\text { Hout-Wolters BHAM }\end{array}$ & Students' adaptation of study strategies when preparing for classroom tests \\
\hline Bulent A, Hakan K, Aydin B & An analysis of undergraduates' study skills \\
\hline
\end{tabular}




\begin{tabular}{|c|c|}
\hline $\begin{array}{l}\text { Dobson JL, Perez J, Linderholm } \\
\text { T }\end{array}$ & Distributed retrieval practice promotes superior recall of anatomy information \\
\hline $\begin{array}{l}\text { Ford, J. K., Smith, E. M., } \\
\text { Weissbein, D. A., Gully, S. M., } \\
\text { \& Salas, E }\end{array}$ & $\begin{array}{l}\text { Relationships of goal orientation, metacognitive activity and practice } \\
\text { strategies with learning outcomes and transfer }\end{array}$ \\
\hline $\begin{array}{l}\text { Gallard-Echenique E, Bullen M, } \\
\text { Marqués-Molías L }\end{array}$ & $\begin{array}{l}\text { Student communication and study habits of first-year university students in } \\
\text { the digital era }\end{array}$ \\
\hline $\begin{array}{l}\text { Mckeachie, W.J., Pintrich, P.R., } \\
\text { Lin, Y. }\end{array}$ & Teaching learning strategies \\
\hline Schmi, S., Yeung, A., Read, J.R. & Students' learning styles and academic performance \\
\hline $\begin{array}{l}\text { Husmann PR, Barger JB, } \\
\text { Schutte AF }\end{array}$ & Study skills in anatomy and physiology: Is there a difference? \\
\hline $\begin{array}{l}\text { Karpicke J, Butler A, Roediger } \\
\mathrm{H}\end{array}$ & $\begin{array}{l}\text { Metacognitive strategies in student learning: do students practice retrieval } \\
\text { when they study on their own? }\end{array}$ \\
\hline Liem, A. D., Lau, S., \& Nie, Y & $\begin{array}{l}\text { The role of self-efficacy, task value, and achievement goals in predicting } \\
\text { learning strategies, task disengagement, peer relationship, and achievement } \\
\text { outcome }\end{array}$ \\
\hline $\begin{array}{l}\text { Lopez EJ, Nandagopal K, } \\
\text { Shavelson RJ, Szu E, Penn J }\end{array}$ & $\begin{array}{l}\text { Self-regulated learning study strategies and academic performance in } \\
\text { undergraduate organic chemistry: an investigation examining ethnically } \\
\text { diverse students }\end{array}$ \\
\hline McCabe J & Metacognitive awareness of learning strategies in undergraduates \\
\hline Roediger H, Karpicke J & Test-enhanced learning: taking memory tests improves long-term retention \\
\hline Scouller, K. M., \& Prosser, M & Students' experiences in studying for multiple choice question examinations \\
\hline $\begin{array}{l}\text { Smith L, Saini B, Krass I, Chen } \\
\text { TF, Bosnic-Anticevich S, } \\
\text { Sainsbury E }\end{array}$ & Pharmacy students' approaches to learning in an Australian university \\
\hline $\begin{array}{l}\text { Weinstein, C. E., Husman, J. and } \\
\text { Dierking, D. R }\end{array}$ & $\begin{array}{l}\text { "Interventions with a focus on learning strategies". In Handbook of } \\
\text { self-regulation, Edited by: Boekaerts, M., Pintrich, P. R. and Zeidner, M }\end{array}$ \\
\hline Yip, M. C. W. & $\begin{array}{l}\text { Relationship of study strategies and academic performance of higher } \\
\text { education: A cross-cultural comparison }\end{array}$ \\
\hline
\end{tabular}


Appendix 4

\begin{tabular}{|c|c|c|c|c|c|}
\hline $\begin{array}{l}\text { First author } \\
\text { and title of } \\
\text { included study }\end{array}$ & Country & $\begin{array}{l}\text { Study design, } \\
\text { duration, and } \\
\text { participants }\end{array}$ & $\begin{array}{l}\text { Type of } \\
\text { Data }\end{array}$ & Outcome & $\begin{array}{l}\text { Quality: } \\
\text { Design/ } \\
\text { score }\end{array}$ \\
\hline $\begin{array}{l}\text { Balasubramaniam et } \\
\text { al, 2016; A Study of } \\
\text { Learning Style } \\
\text { Preferences among } \\
\text { First Year } \\
\text { Undergraduate } \\
\text { Medical Students } \\
\text { Using VARK Model }\end{array}$ & India & $\begin{array}{l}\text { Quantitative descriptive } \\
\text { design; One-time } \\
\text { questionnaire (VARK) } \\
\text { filling-out period (exact } \\
\text { time not specified) given } \\
\text { to first year } \\
\text { undergraduate students } \\
\text { (n=152, only } 144 \\
\text { completed successfully) }\end{array}$ & $\begin{array}{l}\text { Questionnaire } \\
\mathrm{s}(\mathrm{n}=144)\end{array}$ & $\begin{array}{l}48 \% \text { of participants preferred unimodality, and } \\
52 \% \text { preferred multimodality. Within the } \\
\text { unimodal learning sample, } 35 \% \text { used kinaesthetic } \\
\text { techniques and } 34 \% \text { used auditory techniques. } \\
\text { Within the multimodal learning sample, } \\
\text { kinesthetic, aural, and visual techniques made up } \\
\text { the majority of learning styles. It was found that } \\
\text { most students preferred the multimodal learning } \\
\text { approach, which suggests that the implementation } \\
\text { of multimedia may effectively accommodate their } \\
\text { learning styles. }\end{array}$ & $4 / * * * * *$ \\
\hline $\begin{array}{l}\text { Baykan et al, 2007; } \\
\text { Learning styles of } \\
\text { first-year medical } \\
\text { students attending } \\
\text { Erciyes University in } \\
\text { Kayseri, Turkey }\end{array}$ & Turkey & $\begin{array}{l}\text { Quantitative descriptive } \\
\text { design; Questionnaire } \\
\text { (VARK) given to fill out } \\
\text { at the beginning of the } \\
\text { semester (exact time not } \\
\text { specified); Administered } \\
\text { to first-year medical } \\
\text { students ( }=162 \text {, only } \\
155 \text { completed } \\
\text { successfully) }\end{array}$ & $\begin{array}{l}\text { Questionnaire } \\
\mathrm{s}(\mathrm{n}=155)\end{array}$ & $\begin{array}{l}\text { After administering VARK it was found that the } \\
36.1 \% \text { of the sample preferred unimodality, and } \\
63.9 \% \text { preferred multimodality. Additionally, } \\
23.3 \% \text { used kinesthetic techniques, } 7 / 7 \% \text { used } \\
\text { auditory techniques, } 3.2 \% \text { used visual techniques, } \\
\text { and } 1.9 \% \text { used read-write techniques in their } \\
\text { learning strategies. } 30.3 \% \text { of participants had } \\
\text { bimodal approaches, } 20.7 \% \text { had trimodal } \\
\text { approaches, and } 12.9 \% \text { had quad-modal } \\
\text { approaches. No significant differences in learning } \\
\text { style preferences were observed between males } \\
\text { and females, and no significant relationship was } \\
\text { observed between student GPAs and their } \\
\text { learning preferences. }\end{array}$ & $4 / * * * * *$ \\
\hline $\begin{array}{l}\text { Credé et al, 2008; } \\
\text { Study Habits, Skills, } \\
\text { and Attitudes: The } \\
\text { Third Pillar } \\
\text { Supporting } \\
\text { Collegiate Academic } \\
\text { Performance }\end{array}$ & USA & $\begin{array}{l}\text { Qualitative design; } \\
\text { Meta-analysis (exact } \\
\text { time not specified) of } \\
\text { studies ( } \mathrm{n}=72,431) \\
\text { concerning } 10 \text { study skill } \\
\text { constructs; }\end{array}$ & $\begin{array}{l}\text { Studies } \\
(\mathrm{n}=72,431)\end{array}$ & $\begin{array}{l}\text { Learning strategy/skill inventories don't often } \\
\text { depend on highschool admission test scores, but } \\
\text { they do have a slight relation to personality } \\
\text { constructs. It was found that motivation and study } \\
\text { skills have the highest correlation with student } \\
\text { gpa and course success. Inventories that are most } \\
\text { predictive of performance are regarding study } \\
\text { habits and attitude. Anxiety rooted in academics } \\
\text { also seemed to be a negative predictor of student } \\
\text { performance. }\end{array}$ & $1 / * * * * *$ \\
\hline $\begin{array}{l}\text { Diseth, 2011; } \\
\text { Self-efficacy, goal } \\
\text { orientations and } \\
\text { learning strategies } \\
\text { as mediators } \\
\text { between preceding } \\
\text { and subsequent } \\
\text { academic }\end{array}$ & Norway & $\begin{array}{l}\text { Quantitative descriptive } \\
\text { design; Inventories were } \\
\text { given out ( } 15 \text { min. to } \\
\text { complete) to } \\
\text { undergraduate } \\
\text { psychology students } \\
\text { (n=211, only } 177 \\
\text { completed correctly) }\end{array}$ & $\begin{array}{l}\text { Questionnaire } \\
\mathrm{s}(\mathrm{n}=177) \\
\text { Inventory } \\
\text { before exam, } \\
\text { highschool } \\
\text { GPA, } \\
\text { examination } \\
\text { grade, }\end{array}$ & $\begin{array}{l}\text { It was found that a strong relationship exists } \\
\text { between the learning strategies of } \\
\text { self-efficacy/goal orientations and deep/surface } \\
\text { learning. Additionally, preceding academic } \\
\text { achievement was found to predict self-efficacy } \\
\text { and future achievement. }\end{array}$ & $/ * * * *$ \\
\hline
\end{tabular}




\begin{tabular}{|c|c|c|c|c|c|}
\hline achievement. & & & $\begin{array}{l}\text { ASSIST } \\
\text { inventory }\end{array}$ & & \\
\hline $\begin{array}{l}\text { Dobson et al, 2014; } \\
\text { Self-testing promotes } \\
\text { superior retention of } \\
\text { anatomy and } \\
\text { physiology } \\
\text { information }\end{array}$ & USA & $\begin{array}{l}\text { Randomized controlled } \\
\text { trials design; Phase } 1 \text { and } \\
\text { phase } 2 \text { were conducted } \\
\text { over the course of more } \\
\text { than a week with } \\
\text { undergraduates from an } \\
\text { Anatomy and Physiology } \\
\text { I course ( } \mathrm{n}=147, \text { with } \\
\text { only } 125 \text { being included) }\end{array}$ & $\begin{array}{l}\text { Examinations } \\
(\mathrm{n}=5) \\
\text { observations } \\
\text { (more than a } \\
\text { week), } \\
\text { questionnaires }\end{array}$ & $\begin{array}{l}\text { The reading, testing, and rereading strategy } \\
\text { (R-T-R) was found to significantly increase } \\
\text { students' ability to retain information after a week } \\
\text { of its implementation. Additionally, the } \\
\text { implementation of self-testing instructions } \\
\text { seemed to aid students in preparing for course } \\
\text { examinations. }\end{array}$ & $2 / * * * *$ \\
\hline $\begin{array}{l}\text { Dobson, } 2009 ; \\
\text { Learning style } \\
\text { preferences and } \\
\text { course performance } \\
\text { in an undergraduate } \\
\text { physiology class }\end{array}$ & USA & $\begin{array}{l}\text { Quantitative descriptive } \\
\text { design; Questionnaire } \\
\text { (VARK) given out (exact } \\
\text { time not specified) to } \\
\text { undergraduate students in } \\
\text { Applied Human } \\
\text { Physiology courses } \\
\text { (n=1,037, with only } 901 \\
\text { being included) }\end{array}$ & $\begin{array}{l}\text { Questionnaire } \\
\mathrm{s}(\mathrm{n}=901)\end{array}$ & $\begin{array}{l}\text { It was found that there are significantly different } \\
\text { learning style preferences between male and } \\
\text { females. } 46 \% \text { of females preferred visual } \\
\text { learning, } 27 \% \text { preferred read/write methods, and } \\
4 \% \text { preferred kinesthetic. However, } 49 \% \text { males } \\
\text { seemed to prefer visual learning, } 29 \% \text { preferred } \\
\text { read/write methods, } 17 \% \text { preferred aural, and } 5 \% \\
\text { preferred kinesthetic. Additionally, it was found } \\
\text { that there was a significant relationship regarding } \\
\text { sensory modality and student course scores. }\end{array}$ & $4 / * * * *$ \\
\hline $\begin{array}{l}\text { Drago et al, 2004; } \\
\text { Vark preferred } \\
\text { learning styles and } \\
\text { online education }\end{array}$ & USA & $\begin{array}{l}\text { Quantitative descriptive } \\
\text { design; Review of VARK } \\
\text { preferred learning style } \\
\text { and online education } \\
\text { (exact time not } \\
\text { specified); VARK } \\
\text { administered to students } \\
\text { from } 11 \text { MBA } \\
\text { management courses at } \\
\text { the end of each semester } \\
\text { ( } \mathrm{n}=527, \text { with only } 326 \\
\text { completed successfully) }\end{array}$ & $\begin{array}{l}\text { Questionnaire } \\
\text { s (n=326), } \\
\text { Studies }\end{array}$ & $\begin{array}{l}\text { It was found that students completing school } \\
\text { online were more likely to have more } \\
\text { well-developed visual and read-write learning } \\
\text { strategies. Those that preferred read-write } \\
\text { methods and other students who had } \\
\text { well-developed skills across all } 4 \text { learning styles } \\
\text { were found to be more likely to evaluate the } \\
\text { effectiveness of a course lower in comparison to } \\
\text { other students. Students that preferred } \\
\text { aural/read-write methods were individuals who } \\
\text { did not have well-developed skills in other } \\
\text { learning styles. These students were found to be } \\
\text { more likely to evaluate course effectiveness } \\
\text { higher. }\end{array}$ & $4 / * * * *$ \\
\hline $\begin{array}{l}\text { Elliot et al, } 1999 ; \\
\text { Achievement goals, } \\
\text { study strategies, and } \\
\text { exam performance: } \\
\text { A mediational } \\
\text { analysis. }\end{array}$ & USA & $\begin{array}{l}\text { Quantitative descriptive } \\
\text { design; } 2 \text { studies } \\
\text { conducted analyzing } \\
\text { achievement goals over a } \\
\text { total of } 343 \\
\text { undergraduates enrolled } \\
\text { in an introductory level } \\
\text { psychology course (only }\end{array}$ & $\begin{array}{l}\text { Questionnaire } \\
\mathrm{s}(\mathrm{n}=343)\end{array}$ & $\begin{array}{l}\text { It was found that mastery goals positively predict } \\
\text { persistence, deep processing, and effort in } \\
\text { students. With performance-approach goals, it } \\
\text { seemed that they acted as positive predictors for } \\
\text { surface processing, persistence, exam } \\
\text { performance, and effort as well. } \\
\text { Performance-avoidance goals also positively } \\
\text { predicted surface processing, along with } \\
\text { disorganization. Yet it seemed to additionally act } \\
\text { as a negative predictor for deep processing and } \\
\text { exam performance. Overall, it was shown that } \\
\text { persistence and effort moderated the relationship } \\
\text { between performance-approach goals and exam } \\
\text { performance, with disorganization moderating } \\
\text { exam performance and performance-avoidance } \\
\text { goals instead. }\end{array}$ & $4 / * * * *$ \\
\hline
\end{tabular}




\begin{tabular}{|c|c|c|c|c|c|}
\hline $\begin{array}{l}\text { Farkas et al, 2015; } \\
\text { Learning style versus } \\
\text { time spent studying } \\
\text { and career choice: } \\
\text { Which is associated } \\
\text { with success in a } \\
\text { combined } \\
\text { undergraduate } \\
\text { anatomy and } \\
\text { physiology course? }\end{array}$ & USA & $\begin{array}{l}\text { Quantitative descriptive } \\
\text { design; }\end{array}$ & $\begin{array}{l}\text { Questionnaire } \\
\mathrm{s}(\mathrm{n}=492)\end{array}$ & $\begin{array}{l}\text { It was found that the amount of study time was } \\
\text { not significantly correlated with the style of } \\
\text { learning or student career plans. Career choices } \\
\text { and study time seemed to be correlated with } \\
\text { higher student achievement. }\end{array}$ & $4 / * * * * *$ \\
\hline \begin{tabular}{|l|} 
Duncan et al, $1996 ;$ \\
Assessing students' \\
motivation and \\
learning strategies in \\
the classroom \\
context: The \\
Motivated Strategies \\
for Learning \\
Questionnaire.
\end{tabular} & USA & $\begin{array}{l}\text { Qualitative design; } \\
\text { Reviews of studies } \\
\text { regarding motivation and } \\
\text { cognitive components in } \\
\text { a classroom context; } \\
\text { (participants aren't really } \\
\text { specified, it talks about } \\
\text { studies in a more general } \\
\text { sense) }\end{array}$ & $\begin{array}{l}\text { Studies, } \\
\text { Questionnaire } \\
\text { s (used in } \\
\text { those studies) }\end{array}$ & $\begin{array}{l}\text { The Motivated Strategies for Learning } \\
\text { Questionnaire is deemed to be fairly reliable, with } \\
\text { response accuracy depending on the } \\
\text { characteristics of particular questions (ex. Length, } \\
\text { phrasing). It was found that the learning strategies } \\
\text { scales included in this questionnaire positively } \\
\text { correlated with student performance in terms of } \\
\text { course grades. This study demonstrated that the } \\
\text { MSLQ is a valid approach to analyzing student } \\
\text { motivation and study strategies within schooling. }\end{array}$ & $1 / * * * * *$ \\
\hline $\begin{array}{l}\text { Hartwig et al, 2012; } \\
\text { Study strategies of } \\
\text { college students: are } \\
\text { self-testing and } \\
\text { scheduling related to } \\
\text { achievement? }\end{array}$ & USA & $\begin{array}{l}\text { Quantitative descriptive } \\
\text { design; Administered } \\
\text { questionnaires (exact } \\
\text { time not specified) to } \\
\text { undergraduate students in } \\
\text { KSU participant pool } \\
(\mathrm{n}=324)\end{array}$ & $\begin{array}{l}\text { Questionnaire } \\
\mathrm{s}(\mathrm{n}=324)\end{array}$ & $\begin{array}{l}\text { Self-testing, rereading, and scheduling of study } \\
\text { time were all important factors regarding GPA, } \\
\text { with positive associations with the first } 2 \\
\text { strategies. It was found that high-achieving } \\
\text { students were less likely to participate in } \\
\text { late-night studying in comparison to } \\
\text { low-achieving students, who also seemed to be } \\
\text { driven by deadlines. Additionally, the } \\
\text { accumulation of study was found to be associated } \\
\text { with the use of fewer study strategies. }\end{array}$ & $4 / * * * *$ \\
\hline $\begin{array}{l}\text { Yip, 2012; Learning } \\
\text { strategies and } \\
\text { self-efficacy as } \\
\text { predictors of } \\
\text { academic } \\
\text { performance: a } \\
\text { preliminary study }\end{array}$ & China & $\begin{array}{l}\text { Quantitative descriptive } \\
\text { design; Administered } \\
\text { revised LASSI-C } \\
\text { questionnaire }(20 \mathrm{~min}) \text { to } \\
\text { undergraduate students } \\
\text { (n=215, only } 200 \\
\text { completed successfully) }\end{array}$ & $\begin{array}{l}\text { Questionnaire } \\
\mathrm{s}(\mathrm{n}=200)\end{array}$ & $\begin{array}{l}\text { It was found that, by comparing high-achieving } \\
\text { and low-achieving students, major differences } \\
\text { can be observed. In particular, self-efficacy acted } \\
\text { as a good indicator between both student groups } \\
\text { in a university setting. }\end{array}$ & $4 / * * * *$ \\
\hline $\begin{array}{l}\text { Zhou et al, 2016; } \\
\text { The relationship } \\
\text { between study } \\
\text { strategies and } \\
\text { academic } \\
\text { performance }\end{array}$ & USA & $\begin{array}{l}\text { Quantitative descriptive } \\
\text { design; Lassi nd SDLRS } \\
\text { questionnaires were } \\
\text { administered (over a } \\
\text { session, exact time not } \\
\text { specified) to medical } \\
\text { students before their first } \\
\text { and second years ( } \mathrm{n}=168 \text { ) }\end{array}$ & $\begin{array}{l}\text { Questionnaire } \\
\mathrm{s}(\mathrm{n}=168)\end{array}$ & $\begin{array}{l}\text { The results obtained through SDLRS and LASSI } \\
\text { implementations differ in terms of their predictive } \\
\text { value. While LASSI subscales of concentration, } \\
\text { motivation, time management, and test strategies } \\
\text { seem to correlate with student academic } \\
\text { performance, it seems that SLDRS does not have } \\
\text { any direct relation to the subject. }\end{array}$ & $4 / * * * *$ \\
\hline
\end{tabular}




\begin{tabular}{|c|c|c|c|c|c|}
\hline $\begin{array}{l}\text { Khalil et al, 2017; } \\
\text { The Relationship } \\
\text { Between Learning } \\
\text { and Study Strategies } \\
\text { Inventory (LASSI) } \\
\text { and Academic } \\
\text { Performance in } \\
\text { Medical Schools }\end{array}$ & USA & $\begin{array}{l}\text { Quantitative descriptive } \\
\text { design; LASSI } \\
\text { questionnaire was } \\
\text { administered during } \\
\text { orientation (exact time } \\
\text { not specified) to medical } \\
\text { students starting first and } \\
\text { second year (n=128) }\end{array}$ & $\begin{array}{l}\text { Questionnaire } \\
\mathrm{s}(\mathrm{n}=128)\end{array}$ & $\begin{array}{l}\text { Students that had more experience within medical } \\
\text { school provided more accurate assessments of } \\
\text { learning strategies in comparison to those starting } \\
\text { medical school. It was found that } 3 \text { subscales - } \\
\text { anxiety, selecting main ideas, and test strategies - } \\
\text { all had a correlation with student achievement } \\
\text { during internal and external testing. }\end{array}$ & $4 / * * * * *$ \\
\hline $\begin{array}{l}\text { Khalil et al, 2019; } \\
\text { The Use of Learning } \\
\text { and Study Strategies } \\
\text { Inventory (LASSI) to } \\
\text { Investigate } \\
\text { Differences Between } \\
\text { Low vs High } \\
\text { Academically } \\
\text { Performing Medical } \\
\text { Students }\end{array}$ & USA & $\begin{array}{l}\text { Quantitative descriptive } \\
\text { study, } 180 \text { medical } \\
\text { students from three } \\
\text { classes }\end{array}$ & $\begin{array}{l}\text { Questionnaire } \\
\mathrm{s}(\mathrm{n}=180)\end{array}$ & $\begin{array}{l}\text { By comparing high-achieving and low-achieving } \\
\text { students, it was seen that only } 3 \text { LASSI subscales } \\
\text { provided significant differences between the } 2, \\
\text { being anxiety, motivation, and test strategies. } \\
\text { These scales correlated with both groups during } \\
\text { internal and external tests. }\end{array}$ & $4 / * * * * *$ \\
\hline $\begin{array}{l}\text { Vrugt et al, 2008; } \\
\text { Metacognition, } \\
\text { achievement goals, } \\
\text { study strategies and } \\
\text { academic } \\
\text { achievement: } \\
\text { Pathways to } \\
\text { achievement. }\end{array}$ & Netherlands & $\begin{array}{l}\text { Quantitative descriptive } \\
\text { design; The MSLQ } \\
\text { questionnaire was } \\
\text { administered } 1 \text { week } \\
\text { before an exam (exact } \\
\text { time not specified) to } \\
\text { first-year undergraduate } \\
\text { psychology students } \\
\text { enrolled in the } \\
\text { Introduction to } \\
\text { Psychology course } \\
(\mathrm{n}=952)\end{array}$ & $\begin{array}{l}\text { Questionnaire } \\
\mathrm{s}(\mathrm{n}=952)\end{array}$ & $\begin{array}{l}\text { The metacognitive pathway in self-regulated } \\
\text { learning incorporated positive mastery goals } \\
\text { relationships, while also incorporating negative } \\
\text { performance-avoidance goals relationships within } \\
\text { metacognition. On the contrary, the strategy } \\
\text { pathways incorporated only the positive effects of } \\
\text { mastery and performance-approach goals within } \\
\text { metacognition and deep cognition. Overall, } \\
\text { metacognition had a positive effect on all } 4 \\
\text { strategies of effective self-regulated learning. } \\
\text { Performance-goals also presented positive effects } \\
\text { through surface cognitive and resource } \\
\text { management strategies. }\end{array}$ & $4 / * * * *$ \\
\hline $\begin{array}{l}\text { Alkhateeb at al, } \\
\text { 2014; Assessment of } \\
\text { learning and study } \\
\text { strategies of } \\
\text { university students in } \\
\text { Qatar using an } \\
\text { Arabic translation of } \\
\text { the Learning and } \\
\text { Study Strategies } \\
\text { Inventory }\end{array}$ & Qatar & $\begin{array}{l}\text { Quantitative descriptive } \\
\text { design; LASSI } \\
\text { questionnaire was } \\
\text { administered (exact time } \\
\text { not specified) to } \\
\text { undergraduate university } \\
\text { students ( } \mathrm{n}=413 \text { ) }\end{array}$ & $\begin{array}{l}\text { Questionnaire } \\
\mathrm{s}(\mathrm{n}=413)\end{array}$ & $\begin{array}{l}\text { Of the } 10 \text { scales, only } 9 \text { were found to be } \\
\text { significantly correlated with student GPAs, } \\
\text { providing a statistically significant basis that } \\
\text { presents differences between low-achieving and } \\
\text { high-achieving students. It was found that anxiety } \\
\text { and test strategies predicted academic success in } \\
\text { reference to student GPAs. }\end{array}$ & $4 / * * * *$ \\
\hline $\begin{array}{l}\text { O'Mahony et al, } \\
2016 ; \\
\text { Association between } \\
\text { learning style } \\
\text { preferences and } \\
\text { anatomy assessment } \\
\text { outcomes in } \\
\text { graduate-entry Fand } \\
\text { undergraduate } \\
\text { medical students }\end{array}$ & Ireland & $\begin{array}{l}\text { Quantitative descriptive } \\
\text { design; VARK and LSQ } \\
\text { questionnaires were } \\
\text { administered (exact time } \\
\text { not specified) to first and } \\
\text { second years in the DEM } \\
\text { medical program and } \\
\text { first years in the GEM } \\
\text { program ( } \mathrm{n}=327)\end{array}$ & $\begin{array}{l}\text { Questionnaire } \\
\mathrm{s}(\mathrm{n}=327)\end{array}$ & $\begin{array}{l}\text { A weak correlation between anatomy assessment } \\
\text { performance and multiple LSQ style preferences } \\
\text { were observed. The "Activist" style seemed to } \\
\text { have a negative correlation with anatomy scores } \\
\text { in second year students, while the "Theorist" } \\
\text { seemed to have a weak correlation with anatomy } \\
\text { scores in second year students. Students who } \\
\text { achieved high scores on the VARK "Aural" } \\
\text { modality, however, were found to have improved } \\
\text { anatomy scores. }\end{array}$ & $4 / * * * * *$ \\
\hline
\end{tabular}




\begin{tabular}{|c|c|c|c|c|c|}
\hline $\begin{array}{l}\text { McAndrew et al, } \\
\text { 2016; Dental Student } \\
\text { Study Strategies: Are } \\
\text { Self-Testing and } \\
\text { Scheduling Related } \\
\text { to Academic } \\
\text { Performance? }\end{array}$ & USA & $\begin{array}{l}\text { Quantitative descriptive } \\
\text { design; } 16 \text {-item survey } \\
\text { administered after } \\
\text { preclinical laboratory } \\
\text { sessions (exact time not } \\
\text { specified) to second year } \\
\text { dental students ( } \mathrm{n}=358, \\
\text { only } 94 \text { completed } \\
\text { successfully) }\end{array}$ & $\begin{array}{l}\text { Questionnaire } \\
\mathrm{s}(\mathrm{n}=94)\end{array}$ & $\begin{array}{l}\text { Self-testing and rereading study strategies seemed } \\
\text { to be the techniques used by the majority of the } \\
\text { sample population. It was found that self-testing } \\
\text { (frequently with flashcards) was more likely to be } \\
\text { adopted by high-achieving students, who } \\
\text { commonly spaced out their studying over } \\
\text { multiple sessions. Highlighting or underlining } \\
\text { techniques seemed to be adopted by } \\
\text { low-achieving students, who commonly crammed } \\
\text { their study sessions. Stronger performance was } \\
\text { associated with longer periods of study or } \\
\text { practice, and lower performance was associated } \\
\text { with shorter periods of study or practice. While a } \\
\text { majority of students claimed to believe that } \\
\text { studying would be more productive in the } \\
\text { morning, } 84 \% \text { reported studying during later } \\
\text { hours (evenings, late night). }\end{array}$ & $4 / * * * *$ \\
\hline $\begin{array}{l}\text { Hoskins et al, 2017; } \\
\text { Effectiveness of a } \\
\text { Low-Cost, Graduate } \\
\text { Student-Led } \\
\text { Intervention on Study } \\
\text { Habits and } \\
\text { Performance in } \\
\text { Introductory Biology }\end{array}$ & USA & $\begin{array}{l}\text { Non-randomized design; } \\
\text { Recruitment of } \\
\text { participants occurred } 7 \\
\text { weeks into the semester } \\
\text { (voluntary), targeting } \\
\text { undergraduate students } \\
\text { enrolled in an } \\
\text { introductory biology } \\
\text { course }\end{array}$ & $\begin{array}{l}\text { Observing, } \\
\text { questionnaires }\end{array}$ & $\begin{array}{l}\text { It was found that there was a weak association } \\
\text { between changes in study habits and the quality } \\
\text { of work with changes in performance during } \\
\text { lecture exams. However, this relationship seemed } \\
\text { to only be significant during the Fall semester. } \\
\text { The course structure implemented in this study is } \\
\text { shown to be effective and inexpensive. }\end{array}$ & $3 / * * * *$ \\
\hline $\begin{array}{l}\text { Albaili, 1997; } \\
\text { Differences Among } \\
\text { Low-, Average- and } \\
\text { High-achieving } \\
\text { College Students on } \\
\text { Learning and Study } \\
\text { Strategies }\end{array}$ & $\begin{array}{l}\text { United Arab } \\
\text { Emirates }\end{array}$ & $\begin{array}{l}\text { Quantitative descriptive } \\
\text { design; LASSI } \\
\text { questionnaire was } \\
\text { administered (exact time } \\
\text { not specified) to } \\
\text { undergraduate students } \\
\text { (n=168). GPA was used } \\
\text { as an index of college } \\
\text { academic achievement. }\end{array}$ & $\begin{array}{l}\text { Questionnaire } \\
(\mathrm{n}=168)\end{array}$ & $\begin{array}{l}\text { In terms of questionnaires, it was found that those } \\
\text { that scored lower were low-achieving students, } \\
\text { with higher scores being associated with average } \\
\text { or high-achieving students. No significant } \\
\text { differences were seen between the average or } \\
\text { high-achieving student groups in terms of } \\
\text { scoring. This study showed that Motivation was } \\
\text { considered an important characteristic that } \\
\text { separated low-achieving students from } \\
\text { high-achieving students. }\end{array}$ & $4 / * * * *$ \\
\hline
\end{tabular}




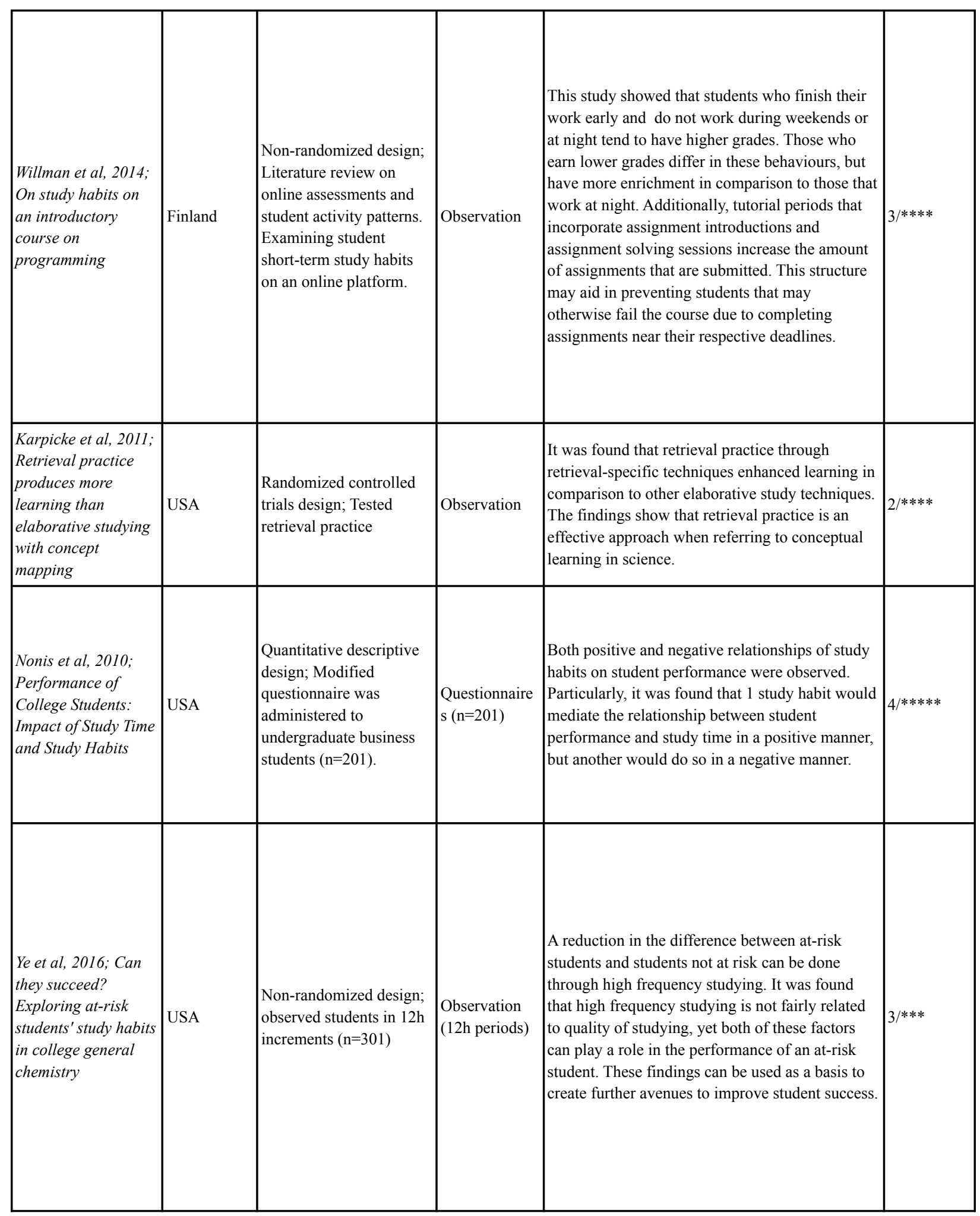




\begin{tabular}{|c|c|c|c|c|c|}
\hline $\begin{array}{l}\text { Yip et al, 2007; } \\
\text { Relationship of Study } \\
\text { Strategies and } \\
\text { Academic } \\
\text { Performance in } \\
\text { Different Learning } \\
\text { Phases of Higher } \\
\text { Education in Hong } \\
\text { Kong }\end{array}$ & China & $\begin{array}{l}\text { Quantitative descriptive } \\
\text { design; LASSI } \\
\text { questionnaires (30min) } \\
\text { were administered to } \\
\text { undergraduate students }\end{array}$ & $\begin{array}{l}\text { Questionnaire } \\
\mathrm{s}\end{array}$ & $\begin{array}{l}\text { Those with high academic achievement in } \\
\text { Matriculation and those with low academic } \\
\text { achievement in Matriculation have study habits } \\
\text { that differ significantly. This particular case, } \\
\text { however, was not seen at University. The } \\
\text { effective strategies outlines in Matriculation } \\
\text { therefore may not be applicable and work } \\
\text { effectively in a university setting. }\end{array}$ & $4 / * * * * *$ \\
\hline $\begin{array}{l}\text { Bickerdike et al, } \\
\text { 2016; Learning } \\
\text { strategies, study } \\
\text { habits and social } \\
\text { networking activity } \\
\text { of undergraduate } \\
\text { medical students }\end{array}$ & Ireland & $\begin{array}{l}\text { Quantitative descriptive } \\
\text { design; ALSI and } \\
\text { demographic } \\
\text { questionnaires were } \\
\text { administered to medical } \\
\text { students in year } 2 \text { and } \\
\text { final year } \\
\text { undergraduate-entry and } \\
\text { graduate-entry medical } \\
\text { students }(\mathrm{n}=376)\end{array}$ & $\begin{array}{l}\text { Questionnaire } \\
\mathrm{s}(\mathrm{n}=376)\end{array}$ & $\begin{array}{l}\text { While surface learning should be discouraged, } \\
\text { effort management and organised studying should } \\
\text { continue to be put forward. This implementation } \\
\text { can optimise academic performance in medical } \\
\text { schools. Poor study habits seem to be correlated } \\
\text { with the excessive use of social networking, and } \\
\text { further contributes to reduced academic } \\
\text { achievement. }\end{array}$ & $3 / * * * * *$ \\
\hline $\begin{array}{l}\text { Boswell, 2016; The } \\
\text { Role Of Study } \\
\text { Strategy Use, } \\
\text { Meaning In Life, And } \\
\text { Grit On The } \\
\text { Academic Success Of } \\
\text { University Students }\end{array}$ & USA & $\begin{array}{l}\text { Quantitative descriptive } \\
\text { design;LASSI-2 was } \\
\text { administered to } 249 \\
\text { undergraduate students } \\
\text { enrolled in psychology } \\
\text { classes }\end{array}$ & $\begin{array}{l}\text { Questionnaire } \\
\mathrm{s}(\mathrm{n}=249)\end{array}$ & $\begin{array}{l}\text { Results show that the types of study strategies } \\
\text { implemented by students accounted for } 31 \% \text { of } \\
\text { the variance in GPA, and grit accounted for } 4 \% \text { of } \\
\text { additional variance. }\end{array}$ & $4 / * * * * *$ \\
\hline $\begin{array}{l}\text { Broekkamp et al, } \\
\text { 2007; Students' } \\
\text { Adaptation of Study } \\
\text { Strategies When } \\
\text { Preparing for } \\
\text { Classroom Tests }\end{array}$ & Netherlands & $\begin{array}{l}\text { Qualitative design; } \\
\text { Review of multiple } \\
\text { studies to develop a } \\
\text { model to further } \\
\text { stimulate research on } \\
\text { strategy adaptation. }\end{array}$ & Studies & $\begin{array}{l}\text { Students of various ages and grade levels can } \\
\text { adapt their study strategies to accommodate } \\
\text { different tasks to some extent, there are still big } \\
\text { issues regarding the types of study strategies used } \\
\text { and environmental impact in implementing these } \\
\text { strategies. Authors suspect that the conditions of } \\
\text { test preparation in the classroom do not support } \\
\text { or promote the adaptability of study strategies. }\end{array}$ & $1 / * * * * *$ \\
\hline $\begin{array}{l}\text { Brown, 2017; An } \\
\text { evidence-based } \\
\text { analysis of learning } \\
\text { practices: the need } \\
\text { for } \\
\text { pharmacy students to } \\
\text { employ more } \\
\text { effective study } \\
\text { strategies }\end{array}$ & USA & $\begin{array}{l}\text { Qualitative design; } \\
\text { Review of multiple } \\
\text { studies to understand } \\
\text { learning practices } \\
\text { (focusing on pharmacy } \\
\text { students) }\end{array}$ & Studies & $\begin{array}{l}\text { Approaching material with study strategies } \\
\text { consisting of superficial understanding and } \\
\text { memorization techniques can be detrimental to } \\
\text { professional growth. Faculty members should } \\
\text { guide students in implementing more effective } \\
\text { evidence-based study strategies. }\end{array}$ & $1 / * * * * *$ \\
\hline
\end{tabular}




\begin{tabular}{|c|c|c|c|c|c|}
\hline $\begin{array}{l}\text { Chen et al, 2015; } \\
\text { The Relationship } \\
\text { Among Academic } \\
\text { Self-concept, } \\
\text { Learning Strategies, } \\
\text { and Academic } \\
\text { Achievement: A Case } \\
\text { Study of National } \\
\text { Vocational College } \\
\text { Students in Taiwan } \\
\text { via SEM }\end{array}$ & Taiwan & $\begin{array}{l}\text { Quantitative descriptive } \\
\text { design; Questionnaires } \\
\text { were administered to } \\
\text { national vocational } \\
\text { college students }(\mathrm{n}=407)\end{array}$ & $\begin{array}{l}\text { Questionnaire } \\
(\mathrm{n}=407)\end{array}$ & $\begin{array}{l}\text { Encouragement from high level educators has } \\
\text { been shown to increase students' motivation to } \\
\text { learn material, efficiency, and self concept. } \\
\text { Academic self-concept has a positive effect on } \\
\text { and may possibly predict academic achievement. } \\
\text { Students showing high levels of self-concept also } \\
\text { demonstrate having internal motivation to } \\
\text { participate in learning. }\end{array}$ & $4 / * * *$ \\
\hline $\begin{array}{l}\text { Costello, 2011; } \\
\text { Achievement goals, } \\
\text { interest, study } \\
\text { strategies, and } \\
\text { academic } \\
\text { achievement }\end{array}$ & USA & $\begin{array}{l}\text { Quantitative descriptive } \\
\text { design; Cluster analysis } \\
\text { was used to examine } \\
\text { study strategies of } \\
\text { undergraduate students } \\
\text { enrolled in introductory } \\
\text { biology ( } \mathrm{n}=119) \text { and } \\
\text { introductory psychology } \\
(\mathrm{n}=57) \text { courses }\end{array}$ & $\begin{array}{l}\text { Questionnaire } \\
(\mathrm{n}=176)\end{array}$ & $\begin{array}{l}\text { Students' mastery, performance-approach and } \\
\text { performance-avoidance goals used to construct } \\
\text { four achievement goal profiles. }\end{array}$ & $4 / * * * *$ \\
\hline $\begin{array}{l}\text { Cukras, 2010; The } \\
\text { Investigation of } \\
\text { Study Strategies that } \\
\text { Maximize Learning } \\
\text { for Underprepared } \\
\text { Students }\end{array}$ & USA & $\begin{array}{l}\text { Non-randomized studies, } \\
13 \text { weeks, } 19 \text { Bronx } \\
\text { Community College } \\
\text { students }\end{array}$ & $\begin{array}{l}\text { Bronx } \\
\text { Community } \\
\text { College's } \\
\text { freshman-leve } \\
1 \text { textbook } \\
\text { chapters, } \\
\text { including } \\
\text { open } \\
\text { discussion and } \\
\text { tests on topics }\end{array}$ & $\begin{array}{l}\text { Certain strategies were found to improve learning } \\
\text { compared to others. These results were found } \\
\text { through teachers meeting with students on an } \\
\text { individual basis and discussing test performance } \\
\text { and strategies selected. }\end{array}$ & $3 / * * *$ \\
\hline $\begin{array}{l}\text { Dill et al, 2014; The } \\
\text { Use of the LASSI } \\
\text { (The Learning and } \\
\text { Study Strategies } \\
\text { Inventory) to Predict } \\
\text { and Evaluate the } \\
\text { Study Habits and } \\
\text { Academic } \\
\text { Performance of } \\
\text { Students in a } \\
\text { Learning Assistance } \\
\text { Program }\end{array}$ & USA & $\begin{array}{l}\text { Quantitative descriptive } \\
\text { design; LASSI } \\
\text { questionnaires (3h) were } \\
\text { administered to students } \\
\text { enrolled in four sections } \\
\text { of a class called } \\
\text { "Fundamentals of } \\
\text { Achievement: } \\
\text { Applications to College, } \\
\text { Work, and Life) }(n=145)\end{array}$ & $\begin{array}{l}\text { Questionnaire } \\
\mathrm{s}(\mathrm{n}=145)\end{array}$ & $\begin{array}{l}\text { Over the course of the study, students' } \\
\text { understanding and use of study strategies } \\
\text { improved according to questionnaire results. } \\
\text { Students identifying as having less anxiety were } \\
\text { more likely to avoid suspension. }\end{array}$ & $4 / * * * * *$ \\
\hline $\begin{array}{l}\text { Dunlosky, 2013; } \\
\text { Strengthening the } \\
\text { Student Toolbox: } \\
\text { Study Strategies to } \\
\text { Boost Learning }\end{array}$ & USA & $\begin{array}{l}\text { Qualitative design; talks } \\
\text { about all the different } \\
\text { learning strategies (ex. } \\
\text { Highlighting, testing, } \\
\text { etc.) }\end{array}$ & & & $1 / * * * * *$ \\
\hline
\end{tabular}




\begin{tabular}{|c|c|c|c|c|c|}
\hline $\begin{array}{l}\text { Fleming, 2002; } \\
\text { Improving Students' } \\
\text { Exam Performance } \\
\text { by Introducing Study } \\
\text { Strategies and Goal } \\
\text { Setting }\end{array}$ & USA & $\begin{array}{l}\text { Quantitative descriptive } \\
\text { design; Questionnaires } \\
\text { were administered to } \\
\text { first-year students in } 2 \\
\text { sections of introductory } \\
\text { psychology ( } \mathrm{n}-=65)\end{array}$ & $\begin{array}{l}\text { Questionnaire } \\
\mathrm{s}(\mathrm{n}=65)\end{array}$ & $\begin{array}{l}\text { Students in the control group overall scored lower } \\
\text { on the first two and last exams, with insignificant } \\
\text { differences for the third exam. First year students } \\
\text { in the treatment group performed similarly to } \\
\text { upper year students on all four exams, } \\
\text { demonstrating comfort in new tools supplied for } \\
\text { learning. }\end{array}$ & $4 / * * * *$ \\
\hline $\begin{array}{l}\text { Foote, 2010; } \\
\text { Student-Generated } \\
\text { Higher Order } \\
\text { Questioning as a } \\
\text { Study Strategy }\end{array}$ & USA & $\begin{array}{l}\text { Randomized controlled } \\
\text { trials design; Created } \\
\text { peer treatments to test } \\
\text { student-generated higher } \\
\text { order questioning as a } \\
\text { study strategy. } \\
\text { Implemented to students } \\
(\mathrm{n}=120) \text { in an } \\
\text { introductory psychology } \\
\text { course at a private } \\
\text { university }\end{array}$ & Observation & $\begin{array}{l}\text { There is no support indicating that one treatment } \\
\text { option results in higher cognitive activity on the } \\
\text { continuum with guided questions scoring } \\
\text { requiring greater amount of mental effort and } \\
\text { connections between concepts formed, compared } \\
\text { to lower-order or fact-listing questions. }\end{array}$ & $2 / * * * *$ \\
\hline $\begin{array}{l}\text { Foutz, 2018; } \\
\text { Collaborative } \\
\text { Argumentation as a } \\
\text { Learning Strategy to } \\
\text { Improve Student } \\
\text { Performance in } \\
\text { Engineering Statics: } \\
\text { A Pilot Study }\end{array}$ & USA & $\begin{array}{l}\text { Investigated if } \\
\text { collaborative } \\
\text { argumentation is a } \\
\text { strategy that can improve } \\
\text { student understanding. } \\
\text { Implemented in a } \\
\text { sophmore-level } \\
\text { engineering course } \\
(\mathrm{n}=60) \text { with } 75 \text { min } \\
\text { lecture sessions twice a } \\
\text { week, followed by a } \\
50 \text { min problem solving } \\
\text { session once a week }\end{array}$ & $\begin{array}{l}\text { Observation } \\
\text { (total of } 15 \\
\text { weeks) }\end{array}$ & $\begin{array}{l}\text { Argumentation improves student performance } \\
\text { according to test scores, although students } \\
\text { demonstrate doubt in the argumentative learning } \\
\text { strategy. Students in both treatment groups had } \\
\text { similar levels of confidence in their ability to } \\
\text { complete the course. }\end{array}$ & $3 / * * *$ \\
\hline $\begin{array}{l}\text { Gallagher, 2020; } \\
\text { Using "Make \& Take } \\
\text { Quizzes" to Improve } \\
\text { Exam Performance } \\
\text { and Engage Students } \\
\text { in Effective Study } \\
\text { Strategies }\end{array}$ & USA & $\begin{array}{l}\text { Non-randomized design; } \\
\text { Examined effectiveness } \\
\text { of in-class quizzing } \\
\text { strategy. Compared } \\
\text { groups of students that } \\
\text { completed }(\mathrm{n}=74) \text { and } \\
\text { did not complete }(\mathrm{n}=73) \\
\text { Make \& Take Quizzes. }\end{array}$ & Testing & $\begin{array}{l}\text { Students provided Make \& Take Quizzes } \\
\text { significantly outperformed students who did not } \\
\text { receive the quizzes. Students' overall study } \\
\text { strategies did not change, but there were slight } \\
\text { changes in two study strategy categories of } \\
\text { identifying main ideas of concepts and } \\
\text { paraphrasing. }\end{array}$ & $3 / * * *$ \\
\hline $\begin{array}{l}\text { Gatto, 2010; } \\
\text { Learning and Study } \\
\text { Strategies of } \\
\text { Baccalaureate } \\
\text { Nursing Students } \\
\text { during First } \\
\text { Semester Nursing } \\
\text { Courses }\end{array}$ & USA & $\begin{array}{l}\text { Quantitative descriptive } \\
\text { study, } 133 \text { students at } \\
\text { two baccalaureate } \\
\text { nursing programs in a } \\
\text { southern state }\end{array}$ & $\begin{array}{l}\text { Questionnaire } \\
(\mathrm{n}=133)\end{array}$ & $\begin{array}{l}\text { Factors of age, number of transfer credits and } \\
\text { learning and study strategies did not identify } \\
\text { academically at-risk students. Having a higher } \\
\text { GPA lowered the risk of being academically } \\
\text { at-risk, while belonging to a minority or } \\
\text { identifying as ESL increased the risk. }\end{array}$ & $4 / * * * *$ \\
\hline
\end{tabular}




\begin{tabular}{|c|c|c|c|c|c|}
\hline $\begin{array}{l}\text { Geller et al, 2017; } \\
\text { Study strategies and } \\
\text { beliefs about } \\
\text { learning as a } \\
\text { function of academic } \\
\text { achievement and } \\
\text { achievement goals }\end{array}$ & USA & $\begin{array}{l}\text { Quantitative descriptive } \\
\text { design; AGQ } \\
\text { questionnaire was } \\
\text { administered to } \\
\text { undergraduate students } \\
\text { enrolled in a introductory } \\
\text { biology course ( } \mathrm{n}=1039 \\
\text { with only } 931 \text { completed } \\
\text { successfully) }\end{array}$ & $\begin{array}{l}\text { Questionnaire } \\
\mathrm{s}(\mathrm{n}=931)\end{array}$ & $\begin{array}{l}\text { High academic achievers were found to } \\
\text { implement more self-testing strategies, less likely } \\
\text { to study last minute, and more likely to plan a } \\
\text { study schedule in advance. Achievement goals } \\
\text { were strong predictors of specific study } \\
\text { behaviours. Avoidance goals were correlated with } \\
\text { increased last minute studying. Individual } \\
\text { differences in student achievement and reasons } \\
\text { for achievement can predict study strategies used. }\end{array}$ & $4 / * * * *$ \\
\hline $\begin{array}{l}\text { Hagemeier et al, } \\
\text { 2011; Student } \\
\text { Pharmacists' } \\
\text { Perceptions of } \\
\text { Testing and Study } \\
\text { Strategies }\end{array}$ & USA & $\begin{array}{l}\text { Quantitative descriptive } \\
\text { design; A survey was } \\
\text { administered to first, } \\
\text { second, and third year } \\
\text { doctor of pharmacy } \\
\text { students }(\mathrm{n}=425)\end{array}$ & Survey & $\begin{array}{l}\text { The main purpose of tests according to students } \\
\text { was to assess the amount of material learned. A } \\
\text { common technique used to study for exams was } \\
\text { massed practice, while retrieval techniques were a } \\
\text { lot less used. }\end{array}$ & $4 / * * * * *$ \\
\hline $\begin{array}{l}\text { Husmann et al, } \\
\text { 2019; Another Nail } \\
\text { in the Coffin for } \\
\text { Learning Styles? } \\
\text { Disparities among } \\
\text { Undergraduate } \\
\text { Anatomy Students' } \\
\text { Study Strategies, } \\
\text { Class Performance, } \\
\text { and Reported VARK } \\
\text { Learning Styles }\end{array}$ & USA & $\begin{array}{l}\text { Quantitative descriptive } \\
\text { design; VARK } \\
\text { questionnaires were } \\
\text { administered to } \\
\text { undergraduate students } \\
\text { enrolled in a basic human } \\
\text { anatomy course }(\mathrm{n}=426)\end{array}$ & $\begin{array}{l}\text { Questionnaire } \\
\mathrm{s}(\mathrm{n}=426)\end{array}$ & $\begin{array}{l}\text { Most students did not report the same study } \\
\text { strategies as the ones found in their VARK } \\
\text { assessment. Student performance was not } \\
\text { correlated with their score in the questionnaires. } \\
\text { Other unrelated study strategies were found to } \\
\text { have a positive correlation with their final grade. }\end{array}$ & $4 / * * * *$ \\
\hline $\begin{array}{l}\text { Khalil et al, } 2018 ; \\
\text { Learning and study } \\
\text { strategies correlate } \\
\text { with medical } \\
\text { students' } \\
\text { performance in } \\
\text { anatomical sciences }\end{array}$ & USA & $\begin{array}{l}\text { Quantitative descriptive } \\
\text { design; LASSI } \\
\text { questionnaires were } \\
\text { administered to medical } \\
\text { students of classes } 2016, \\
\text { 2017, and } 2018(\mathrm{n}=180)\end{array}$ & $\begin{array}{l}\text { Questionnaire } \\
\mathrm{s}(\mathrm{n}=180)\end{array}$ & $\begin{array}{l}\text { There were significant correlations found } \\
\text { between five out of the ten LASSI subscales: } \\
\text { anxiety, information processing, motivation, } \\
\text { selecting main idea and test strategies. Students } \\
\text { lacking these skills were identified and } \\
\text { communicated with, which resulted in improved } \\
\text { academic achievement and test scores. }\end{array}$ & $4 / * * * * *$ \\
\hline
\end{tabular}




\begin{tabular}{|c|c|c|c|c|c|}
\hline $\begin{array}{l}\text { Lopez et al, 2013; } \\
\text { Self-regulated } \\
\text { learning study } \\
\text { strategies and } \\
\text { academic } \\
\text { performance in } \\
\text { undergraduate } \\
\text { organic chemistry: } \\
\text { An investigation } \\
\text { examining ethnically } \\
\text { diverse students }\end{array}$ & USA & $\begin{array}{l}\text { Qualitative design; } \\
\text { Investigated study } \\
\text { strategies of ethnically } \\
\text { diverse students by } \\
\text { collecting study diaries, } \\
\text { concept maps, problem } \\
\text { sets, and final course } \\
\text { grades. }\end{array}$ & Observation & $\begin{array}{l}\text { Results show that the most common } \\
\text { reviewing-type study strategies practiced by } \\
\text { students were similar across all ethnic groups. } \\
\text { These common strategies had little effect on } \\
\text { students' problem solving, concept mapping, or } \\
\text { course performance. Although students knew of } \\
\text { the benefits of metacognitive and peer learning } \\
\text { strategies, these strategies were not implemented. }\end{array}$ & $1 / * * * * *$ \\
\hline $\begin{array}{l}\text { Nist et al, 2010; } \\
\text { Measuring the } \\
\text { affective and } \\
\text { cognitive growth of } \\
\text { regularly admitted } \\
\text { and Developmental } \\
\text { Studies students } \\
\text { using the Learning } \\
\text { and Study Strategies } \\
\text { Inventory (LASSI). }\end{array}$ & USA & $\begin{array}{l}\text { Quantitative descriptive } \\
\text { study, duration?, } 71 \\
\text { regularly-admitted } \\
\text { students volunteering to } \\
\text { enroll in study strategies } \\
\text { course at University of } \\
\text { Arizona, } 168 \\
\text { developmental studies } \\
\text { students mandarily } \\
\text { enrolling in study } \\
\text { strategies course at } \\
\text { University of Georgia }\end{array}$ & $\begin{array}{l}\text { LASSI tests } \\
\text { administered } \\
\text { throughout } \\
\text { duration of the } \\
\text { course } \\
(\mathrm{n}=71+168)\end{array}$ & $\begin{array}{l}\text { Authors found that there was both cognitive and } \\
\text { affective growth experienced by regularly } \\
\text { admitted and developmental students. All LASSI } \\
\text { scales were not good predictors of success in } \\
\text { course work. }\end{array}$ & $4 / * * * *$ \\
\hline $\begin{array}{l}\text { Martins et al, 2019; } \\
\text { Intervention in } \\
\text { Learning Strategies: } \\
\text { Study with New } \\
\text { University Students }\end{array}$ & Brazil & $\begin{array}{l}\text { Quantitative } \\
\text { non-randomized design; } \\
\text { Psychoeducational } \\
\text { intervention programs } \\
\text { were analyzed in students } \\
(\mathrm{n}=83) \text { through } \\
\text { questionnaires }\end{array}$ & Questionnaire & $\begin{array}{l}\text { Qualitative differences in data was collected } \\
\text { which allows the authors to reflect on the } \\
\text { relationship between enrolling in higher } \\
\text { education and the benefit of teaching } \\
\text { self-regulated learning strategies within the first } \\
\text { year of graduation. }\end{array}$ & $3 / * * * *$ \\
\hline $\begin{array}{l}\text { Ross et al, 2006; } \\
\text { College Students' } \\
\text { Study Strategies as a } \\
\text { Function of Testing: } \\
\text { An Investigation into } \\
\text { Metacognitive } \\
\text { Self-Regulation }\end{array}$ & USA & $\begin{array}{l}\text { Quantitative descriptive } \\
\text { design; }\end{array}$ & & $\begin{array}{l}\text { Students who anticipated exam questions that } \\
\text { required deep-level processing used more } \\
\text { deep-level strategies, while students anticipating } \\
\text { exam questions requiring surface-level } \\
\text { knowledge implemented more memory-related } \\
\text { study strategies. }\end{array}$ & $4 / * * * *$ \\
\hline $\begin{array}{l}\text { Sebesta et al, 2017; } \\
\text { How Should I Study } \\
\text { for the Exam? } \\
\text { Self-Regulated } \\
\text { Learning Strategies } \\
\text { and Achievement in } \\
\text { Introductory Biology }\end{array}$ & USA & $\begin{array}{l}\text { Quantitative descriptive } \\
\text { design; Questionnaires } \\
\text { were administered to } \\
\text { students enrolled in an } \\
\text { introductory biology } \\
\text { course }(\mathrm{n}=414)\end{array}$ & $\begin{array}{l}\text { Questionnaire } \\
(\mathrm{n}=414)\end{array}$ & $\begin{array}{l}\text { High academic achievers and students who } \\
\text { experienced an improvement in exam grades used } \\
\text { more specific cognitive strategies more. Low } \\
\text { academic achievers reported not implementing } \\
\text { the strategies they planned to use, or did not help } \\
\text { significantly when used. The authors concluded } \\
\text { that students entering introductory biology are } \\
\text { unfamiliar with learning strategies and the best } \\
\text { methods to implement them to maximize results. }\end{array}$ & $4 / * * * *$ \\
\hline
\end{tabular}




\begin{tabular}{|c|c|c|c|c|c|}
\hline $\begin{array}{l}\text { Senko et al, 2013; } \\
\text { Achievement goals, } \\
\text { study strategies, and } \\
\text { achievement: } \text { A test } \\
\text { of the "learning } \\
\text { agenda" framework }\end{array}$ & USA & $\begin{array}{l}\text { Quantitative descriptive } \\
\text { design; }\end{array}$ & & $\begin{array}{l}\text { MAP goals produce more deep learning strategies } \\
\text { to be implemented. In study } 2 \text {, MAP and PAP } \\
\text { goals were found to both be beneficial to } \\
\text { academic achievement. }\end{array}$ & $4 / * * *$ \\
\hline $\begin{array}{l}\text { Overwalle et al, } \\
\text { 1990; The effects of } \\
\text { attribution-based } \\
\text { intervention and } \\
\text { study strategy } \\
\text { training on academic } \\
\text { achievement in } \\
\text { college freshmen. }\end{array}$ & Belgium & $\begin{array}{l}\text { Randomized controlled } \\
\text { trials design; } \\
\text { Investigating the } \\
\text { effectiveness of remedial } \\
\text { programmes on freshmen } \\
\text { academic performance } \\
\text { (n=43). } 43 \text { watched } \\
\text { video-taped interviews } \\
\text { with senior students } \\
\text { relating the causes of } \\
\text { their failures at the } \\
\text { beginning of the first } \\
\text { year, and how they had } \\
\text { managed to improve their } \\
\text { exam scores at the end of } \\
\text { the year. } 57 \text { learned } \\
\text { conventional rules of } \\
\text { study strategy use and } \\
\text { applied them during short } \\
\text { practice trials. }\end{array}$ & $\begin{array}{l}\text { Observation, } \\
\text { questionnaire }\end{array}$ & $\begin{array}{l}\text { Attribution video manipulation increased the } \\
\text { percent of students who passed the final exam } \\
(18 \% \text { for the first study and } 20 \% \text { for the second } \\
\text { study) compared to the control group who did not } \\
\text { receive exposure to this variable. The learning } \\
\text { strategy course did not produce a significant } \\
\text { effect on academic performance. }\end{array}$ & $2 / * * * *$ \\
\hline $\begin{array}{l}\text { Yip et al, } 2002 ; \\
\text { Relation of Study } \\
\text { Strategies to the } \\
\text { Academic } \\
\text { Performance of } \\
\text { Hong Kong } \\
\text { University Students }\end{array}$ & China & $\begin{array}{l}\text { Quantitative descriptive } \\
\text { design; }\end{array}$ & $\begin{array}{l}\text { Questionnaire } \\
(\mathrm{n}=100)\end{array}$ & $\begin{array}{l}\text { High academic achievers and low academic } \\
\text { achievers differed in scores for the motivation, } \\
\text { scheduling, and selecting main ideas categories. } \\
\text { The results found in this study may apply } \\
\text { differently to students in Western vs. Asian } \\
\text { universities due to the relationship to students' } \\
\text { intrinsic disposition like motivation and } \\
\text { concentration. }\end{array}$ & $4 / * * * *$ \\
\hline $\begin{array}{l}\text { Yip, 2009; } \\
\text { Differences between } \\
\text { high and low } \\
\text { academic achieving } \\
\text { university students in } \\
\text { learning and study } \\
\text { strategies: a further } \\
\text { investigation }\end{array}$ & China & $\begin{array}{l}\text { Quantitative descriptive } \\
\text { design; }\end{array}$ & $\begin{array}{l}\text { Questionnaire } \\
(\mathrm{n}=100)\end{array}$ & $\begin{array}{l}\text { High academic achievers ranked higher on all } \\
\text { categories, including anxiety, attitude, motivation, } \\
\text { concentration, self-testing, scheduling, study aids, } \\
\text { information processing. There were similar } \\
\text { results despite the mode of learning (conventional } \\
\text { vs. distance-learning). }\end{array}$ & $4 / * * * *$ \\
\hline $\begin{array}{l}\text { Yip, 2007; } \\
\text { Differences in } \\
\text { Learning and Study } \\
\text { Strategies between } \\
\text { High and Low } \\
\text { Achieving University } \\
\text { Students: A Hong } \\
\text { Kong study }\end{array}$ & China & $\begin{array}{l}\text { Quantitative descriptive } \\
\text { design; }\end{array}$ & $\begin{array}{l}\text { Questionnaire } \\
(\mathrm{n}=180)\end{array}$ & $\begin{array}{l}\text { High academic achievers had different study } \\
\text { strategies than low achievers, with females } \\
\text { scoring higher than males. A good learning } \\
\text { attitude, self-motivation and proficiency in } \\
\text { adapting better learning and study strategies were } \\
\text { correlated with higher academic achievement. }\end{array}$ & $4 / * * * * *$ \\
\hline
\end{tabular}

